UNIVERSIDADE DE SÃO PAULO

ESCOLA DE ENFERMAGEM

\title{
AÇÕES E PROJETOS DE UM CORPO DOCENTE MULTIPROFISSIONAL EM UM CURSO DE GRADUAÇÃO EM ENFERMAGEM
}

CLÁUDIA PRADO

Tese apresentada à Escola de Enfermagem da USP - São Paulo, para obtenção do título de Doutor em Enfermagem.

Orientadora: Profa. Dra. Maria Madalena Januário Leite

São Paulo 2005 
Catalogação na publicação (CIP)

Biblioteca "Wanda de Aguiar Horta" da EEUSP

Prado, Cláudia

Ações e projetos de um corpo docente multiprofissional em um Curso de Graduação em Enfermagem. / Cláudia Prado. - São Paulo: C. Prado, 2005.

$232 \mathrm{p}$.

Tese (Doutorado) - Escola de Enfermagem da Universidade de São Paulo.

Orientadora: $\operatorname{Prof}^{\mathrm{a}} \operatorname{Dr}^{\mathrm{a}}$ Maria Madalena Januário Leite

1. Enfermagem (Estudo e ensino) 2. Professores (Enfermagem)

3. Fenomenologia. I. Título. 
"Não há certeza absoluta, só a de (re) começar sempre buscando na realidade as pistas sobre o melhor jeito de caminhar".

Thiago de Mello - poeta Amazonense 


\section{De um modo muito especial dedico este trabalho}

Ao meu marido José Manuel, por me amar do seu jeito e por compartilhar comigo uma vida de muita felicidade;

À minha filha Laura, fruto de um grande amor, por ser a maior bênção que já pude receber nesta vida;

Aos meus adorados pais Eduardo e Vânia, por expressarem constantemente seu amor por mim e pela minha família, por estarem sempre presentes em minha vida, e por me ensinarem a viver com dignidade;

À minha irmã Renata, por sua disponibilidade sempre que precisei e pela permanente prova de admiração e amor;

À minha amiga e irmã Silvia, nossa Budi, por nos fazer ver a vida sob outros ângulos, por sua fé e sua sensatez;

Ao meu querido cunhado Rui, pela sua existência em minha vida e por suas formas mais variadas de nos acarinhar. 


\section{AGRADECIMENTOS ESPECIAIS}

Ao ser humano e professora Profa. Dra. Dorisdaia Carvalho de Humerez, inspiradora do projeto inicial deste Doutorado - minha gratidão eterna;

À minha querida orientadora Profa. Dra. Maria Madalena Januário Leite, por me dar asas e permitir meu vôo;

Às preciosas "frutas" (recurso empregado para eu identificar os sujeitos deste estudo), por me ajudarem a compreender melhor o nosso mundovida. 


\section{AGRADECIMENTOS}

Ao meu DEUS, que me concedeu a vida e permitiu chegar até aqui;

A JESUS CRISTO, meu Senhor de luz e proteção;

À Profa. Dra. Maria Sumie Koizumi, por me fazer acreditar e me apaixonar por pesquisa

À Profa. Dra. Terezinha Dalossi Gennari, por ter me dado a oportunidade de aprender a ser docente e por acreditar no meu trabalho;

Às Professoras da Pós-Graduação da EEUSP e aos colegas de disciplinas, pelos deliciosos momentos de reflexão;

À Profa. Dra. Heloísa Helena Ciqueto Peres e Profa. Dra. Suzete Fustinoni, pela compreensão das minhas limitações e pelas valiosas sugestões no exame de qualificação;

À Profa. Dra. Miriam Aparecida Barbosa Merighi, pela paciência em nos ensinar a compreender a fenomenologia;

Aos amigos Humberto e Vanessa, por todos esses anos de prazerosa amizade e por se interessarem por esse meu projeto;

À Wana, por tudo que já passamos juntas nessa vida e por admirar profundamente sua natureza incansável;

À eterna amiga Ana Maria, que sempre me quis bem, acreditou em mim e me impulsionou a buscar novos ideais; 
ao Elias, por estar presente com o calor de sua amizade; à Carol, especialmente querida;

À amiga Ana Lúcia, por sua generosidade, seu caráter admirável e pela imensidão do seu carinho;

Ao novo e para sempre amigo Genival, por me servir de modelo com seu brilhantismo intelectual;

Ao Sr. Atílio Brunacci, pela cuidadosa revisão da língua portuguesa;

Ao Sérgio dos Santos Abreu Filho, pela importante tarefa da tradução de inglês;

Ao Marcos Antonio Vieira, que me acompanha desde o Mestrado e por sua valiosa colaboração na formatação deste trabalho;

À Nadir Aparecida Lopes, pela revisão das referências bibliográficas;

Aos docentes do Curso de Graduação em Enfermagem do UniFMU, por dividirem comigo as dores e as alegrias do diaa-dia da docência; em especial ao Pedro, Cátia, Elaine e Leila por nossas afinidades.

A todas as pessoas que contribuíram direta ou indiretamente, para que eu pudesse concretizar este tão sonhado trabalho. 
PRADO, C. Ações e projetos de um corpo docente multiprofissional em um Curso de Graduação em Enfermagem. São Paulo, 2005. 232 p. Tese (Doutorado) - Escola de Enfermagem. Universidade de São Paulo.

\section{RESUMO}

Este estudo teve a intenção de compreender as ações e os projetos dos docentes enfermeiros e docentes de outras áreas da saúde em um curso de graduação em enfermagem. Nessa perspectiva, os sujeitos envolvidos foram quatro docentes enfermeiros e quatro docentes de outras áreas da saúde que vivenciaram a situação da docência, sendo, por isso, capazes de atribuir significados às suas experiências. A obtenção dos discursos foi feita por meio de duas questões norteadoras: "Como tem sido suas ações docentes neste curso de Enfermagem? O que você espera agindo desta forma?" O referencial de análise utilizado foi a fenomenologia social de Alfred Schütz. Os discursos levaram à construção do mesmo tipo vivido dos docentes enfermeiros e de dos docentes de outras áreas da saúde como sendo aqueles que desejam colaborar no crescimento pessoal do aluno e o vêem como futuro profissional; que atuam com um perfil de alunos com bagagem de conhecimentos $e$ experiências heterogêneas; que acreditam que ser docente é também ser pesquisador; que têm a intenção de fornecer os conteúdos programáticos propostos pela disciplina; que demonstram grande preocupação e interesse em diversificar as estratégias de ensino; que agem tendo a visão de que ser docente é acreditar na valorização e respeito à diversidade de alunos mas que também vivenciam sentimentos distintos. Pode-se constatar que a reciprocidade das ações e dos projetos desses sujeitos 
reforça a importância da composição de um corpo docente multiprofissional, validando o conceito da interdisciplinaridade e desmistificando a idéia de que o fazer dos docentes enfermeiros seja diferente do fazer dos docentes de outras áreas da saúde.

Palavras-chave: Enfermagem (Estudo e ensino); Professores (Enfermagem); Fenomenologia. 
PRADO, C. Attitudes and Projects of an interdisciplinary teaching staff of a Nursing Undergraduate Course. São Paulo, 2005. 232 p. Thesis (Doctorate) - São Paulo University Nursing School.

\section{ABSTRACT}

This study aimed to understand the attitudes and projects of a nursing teaching staff and the ones from other healthcare areas of a nursing undergraduate course. In this perspective, the subjects of this study were 4 nursing teachers and 4 other healthcare teachers who faced this situation, in which they were able to evaluate their experiences. Discourses were obtained by guiding questions: How have your teaching attitudes been in this nursing course? What do you expect acting this way? It was used the social phenomenology by Alfred Schütz as referential of analysis. The discourses led to build the same kind experienced by the nursing teaching staff and the ones from other healthcare areas as the person who wants to collaborate for the students' self-growth and see him/her as a future professional, who works with a student's profile that has heterogeneous knowledge and experience background, who believes that being a teacher is also being a researcher, who intends to provide program content proposed by the discipline, who show much concern and interest in diversifying the teaching strategies, who act keeping in mind that being a teacher is believing in value and respect the diversity of students that live distinct feelings. It's possible to establish that reciprocity of attitudes and projects of these subjects reinforce the importance of a interdisciplinary teaching staff composition, validating the concept of interdisciplinary and, hence, breaking up the idea that 
teaching staff work must be different from the ones from other healthcare areas.

Keywords: Nursing (Study and teaching); Teaching staff (Nursing); Phenomenology. 


\section{SUMÁRIO}

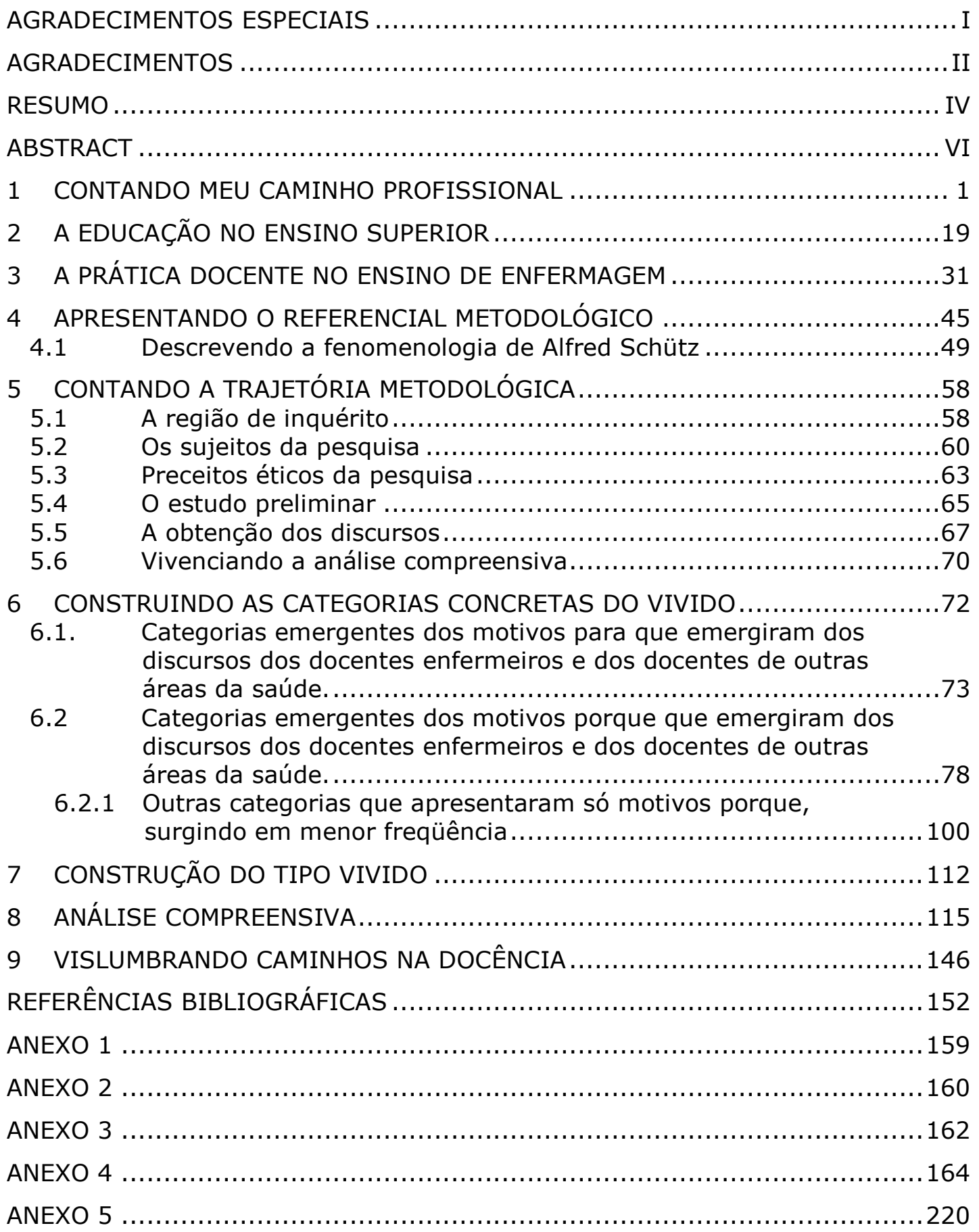




\section{CONTANDO MEU CAMINHO PROFISSIONAL}

Quando penso em que época aconteceu minha escolha profissional, relembro ter sido no tempo em que estava prestando o vestibular da Fuvest (Fundação para o Vestibular), em 1982. Tive que optar nessa ocasião por uma carreira, mesmo sem saber o que gostaria de fazer. Escolhi as carreiras de Enfermagem, Nutrição, Fonoaudiologia e Direito. Tendo sido aprovada nos vestibulares de cada uma dessas áreas, optei pela Enfermagem por ser em uma universidade gratuita, vinculada ao governo federal e, principalmente, com credibilidade acadêmica.

Assim, em 1983 iniciei meu curso de Graduação em Enfermagem na antiga Escola Paulista de Medicina - EPM - hoje Universidade Federal de São Paulo - UNIFESP. Foram três anos de graduação e um ano de habilitação em Enfermagem MédicoCirúrgica. Isso porque, entre as outras áreas disponíveis, Saúde Pública e Obstetrícia, essa foi a área com a qual me identifiquei mais.

Aos poucos, fui gostando do curso e me tornando uma aluna envolvida com a minha formação. $O$ meu relacionamento com os docentes era bom, porém superficial. 
Acredito que "eram outros tempos", quando tínhamos mais dificuldades para estreitar relações com os professores.

Percebo que me tornei a enfermeira que sou hoje por ter escolhido como modelo uma professora - enfermeira também de Fundamentos de Enfermagem, a qual teve um significado especial em minha vida profissional. Mesmo sendo uma pessoa extremamente exigente e rigorosa deixava "boas lembranças" em seus alunos. Com efeito, sua habilidade de ensinar era voltada para o aluno visto como pessoa humana e não apenas como um futuro profissional.

Esse tipo de relação foi profundamente prazeroso e rico, sendo impossível esquecê-la; serviu como um importante aspecto facilitador da minha aprendizagem. Em contrapartida, as disciplinas em que encontrei maiores dificuldades de entendimento estavam, de uma maneira geral, ligadas a professores que passaram por mim quase desapercebidos.

$\mathrm{Na}$ verdade, os docentes dessas disciplinas, que não eram da área de enfermagem, mantinham uma postura de distância dos alunos. Com pouco envolvimento emocional, aparentemente preocupavam-se em demonstrar muito mais seu conhecimento técnico-científico do que o desejo de manter uma relação interpessoal mais estreita com os alunos. Nessa época, 
porém, não me dava conta da importância do professor enquanto "pessoa" na minha aprendizagem.

Formei-me em 1985, com 21 anos de idade. No ano seguinte, prestei concurso público para ingressar no Hospital das Clínicas - São Paulo. Tendo sido aprovada, comecei a trabalhar na Unidade de Terapia Intensiva (UTI) do Pronto-Socorro (PS). Concomitantemente, cursava a Habilitação de Enfermagem MédicoCirúrgica.

Recém-formada e com pouca idade, de um lado; o ambiente do porte do Hospital das Clínicas, do outro; foram fatores que, a um só tempo, me fizeram sofrer e adquirir rápido amadurecimento profissional. Desse modo, descortinaram-me a possibilidade de sentir a Enfermagem como uma carreira de significativos desafios pessoais e profissionais.

Em 1987, assumi pela primeira vez a função de supervisora de estágio de Pronto Socorro (PS) do Curso de Graduação em Enfermagem de uma universidade particular de São Paulo. Nessa época, atuava como enfermeira do PS do Hospital das Clínicas; por me sentir familiarizada com o campo, não tive grandes dificuldades em acompanhar o estágio. 
Permaneci como enfermeira desse hospital durante nove anos, onde atuei em diversas unidades: Pronto-Socorro Cirúrgico, Cirurgia Vascular, Unidade de Fígado e UTI Neurológica. Dele me desliguei em 1995, quando exercia a função de enfermeira chefe.

Nesses anos todos, adquiri grande experiência na área assistencial em decorrência da gravidade dos problemas dos pacientes sob os meus cuidados. Adquiri também valiosa habilidade nas funções administrativas por exercer o cargo de chefia de uma unidade complexa atendida por muitos funcionários. Apesar de me sentir realizada nessas frentes de trabalho, eu me dava conta da necessidade de aprender sempre mais e ansiava por ir além da vivência e dos conhecimentos até então adquiridos.

$\mathrm{Na}$ realidade, todas essas realizações me distanciavam da vida acadêmica. Esse distanciamento começava a me inquietar porque sentia a importância de me atualizar, de reciclar meus conhecimentos e, a partir daí, iniciar na área da pesquisa. Nesse mesmo ano de 1995, ingressei no Grupo de Estudos de Enfermagem em Neurotrauma: epidemiologia e assistência - GENT - da Escola de Enfermagem da Universidade de São Paulo - USP - sob coordenação da Profa. Dra. Maria Sumie 
Koizumi. Um dos objetivos deste grupo era desenvolver pesquisa científica nessa área específica da Enfermagem.

Perseguir tal objetivo tornou-se um desafio para o grupo uma vez que tínhamos que produzir trabalhos para apresentações em congressos e elaborar artigos para publicações; isso porque a maioria de seus componentes era relativamente inexperiente na área da pesquisa. Entretanto, nosso convívio foi se intensificando e se tornando produtivo na medida em que tínhamos uma meta a atingir. Com disciplina, união e apoio incondicional da coordenadora do grupo, fomos nos firmando enquanto estudiosas dessa área e crescendo muito como pesquisadoras.

Acredito que muitos projetos do GENT foram concretizados, em grande parte devido à confiança, ao respeito e à credibilidade recíprocas entre o grupo e a coordenadora, bem como na sua capacidade de visualizar cada elemento como um ser único, com suas limitações e competências.

Em 1996 iniciei como docente no curso de auxiliar e técnico de enfermagem do Centro de Formação de Ciências da Saúde - CEFACS, do Instituto do Coração - INCOR, da Faculdade de Medicina da USP, assumindo disciplinas teóricas e supervisão de estágios. Foi uma experiência muito importante na minha vida agora como docente -pois tive oportunidade de repassar os 
conhecimentos adquiridos juntamente com a prática hospitalar para alunos de Enfermagem.

Desde essa época, comecei a me questionar, sobre qual seria a minha formação didático-pedagógica para desempenhar a tarefa de docente. Como estímulo, eu sentia os alunos chegarem às aulas ávidos de novos conhecimentos e de trocas de experiências, com muito interesse e esforço para concretizarem sua aprendizagem. Foram eles que me impulsionaram a trilhar caminhos que me auxiliaram a transmitir o conteúdo das aulas de uma maneira interativa e atraente, totalmente avessa a um método que denotasse passividade de ambos os lados.

Buscava estratégias de ensino que pudessem envolver os alunos com a própria aprendizagem; servia-me de recursos audiovisuais que facilitassem a compreensão do conteúdo. E como não podia deixar de ser, também tentei estabelecer uma relação interpessoal baseada no respeito, na confiança e no diálogo, colocando-me à disposição para esclarecer qualquer dúvida que pudesse surgir. Ou seja, tentava estabelecer uma relação dinâmica e sincera com todos, transformando a sala de aula em um espaço de criação, crescimento e prazer mediante uma postura simples, porém marcante. Esse comportamento de um lado 
pretendia demonstrar paixão pelo que ensinava, de outro, a crença na competência dos educandos.

Trocava experiências do dia-a-dia da docência com a coordenadora e com os docentes desse curso, todos enfermeiros, com a intenção de ministrar um ensino qualificado.

Mesmo com todo esse meu empenho, em inúmeros momentos sentia uma veemente insegurança em ocasiões em que não tinha certeza se estava me conduzindo de forma adequada ou se estava fazendo as melhores opções tanto do ponto de vista didático-pedagógico quanto no relacionamento que mantinha com os alunos. Procurando não alimentar essa insegurança, fui aos poucos sentindo-me mais segura e acabei permanecendo nessa escola por quatro anos.

No ano de 1997, atuei como docente do curso de instrumentação cirúrgica do Serviço Nacional de Aprendizagem Comercial - SENAC - São Paulo assumindo a teoria e a prática desse curso. Essa escola tem como missão proporcionar o desenvolvimento de pessoas e organizações para a sociedade do conhecimento, por meio de ações educacionais comprometidas com a responsabilidade social. 
Essa instituição possuía um excelente acervo de vídeos educativos para serem utilizados como suporte das aulas teóricas. Por acreditar que a aprendizagem possa se concretizar por meio de diversas formas de ensinar, mediante o emprego desses vídeos em sala de aula pude adquirir maior habilidade na utilização desse recurso audiovisual.

Nas aulas do SENAC, de certa forma, eu também levei comigo as preocupações de ser uma facilitadora da aprendizagem, razão pela qual pensava na escolha das estratégias mais adequadas, no uso de recursos atraentes e no estabelecimento de relações pedagógicas mais abertas e participativas.

Todas essas experiências docentes foram profundamente gratificantes e satisfatórias. Mesmo assim, sentia que muito ainda havia a ser aprendido no exercício do magistério. Desse modo, percebia, cada vez mais, a necessidade, de conviver com os alunos numa esfera que extrapolasse o nível técnicocientífico.

Foi então que surgiu o desejo de fazer a pósgraduação em nível de Mestrado na Escola de Enfermagem da USP, uma vez que me sentia em condições de descobrir e aprofundar novos saberes. É importante dizer que, para isso, foi necessário um 
grande esforço em relação ao aprendizado da língua inglesa, requisito indispensável para ser aprovada no processo seletivo desse curso desejado.

Mais uma dificuldade surgida na minha vida e que eu deveria superar. Dessa vez, então, me senti impulsionada, estimulada e acreditada na minha capacidade por um professor de inglês extremamente jovem - na época com 20 anos - que assegurava ser eu capaz de vencer mais um desafio. Essa confiança em mim depositada impulsionou-me fortemente para a conquista do meu objetivo.

Assim, em fevereiro de 1998 ingressei no Mestrado dessa escola na área de Fundamentos de Enfermagem tendo como orientadora Profa. Dra. Maria Sumie Koizumi, a quem me referi acima.

A escolha do tema da minha futura dissertação foi sustentada na minha prática hospitalar na área de neurologia, neurocirurgia e neurotrauma. Verifiquei a aprendizagem da Escala de Coma de Glasgow por meio de duas técnicas de ensino - aula expositiva e estudo dirigido junto a enfermeiros de Pronto-Socorro.

Os resultados mostraram que o grupo no qual foi aplicada a aula expositiva apresentou incremento estatisticamente 
significativo da fase pré-teste para a pós-teste em 29,8\%; resultados muito superiores a outra técnica estudada, na qual também houve, incremento estatisticamente significativo da fase pré-teste para a pós-teste, porém na ordem de $8,2 \%$ (Prado, 2001).

Sendo a técnica da aula expositiva a mais utilizada no ensino, inclusive no ensino superior, não pude deixar de analisar neste estudo um elemento de fundamental importância que é o professor. Em função disso, fui buscar, na literatura, respostas que me conduzissem a compreender a importância dele no processo de ensino-aprendizagem, sem deixar de considerar a importância do relacionamento que estabelece com os alunos.

A partir dessas análises, pude refletir mais amplamente sobre os aspectos do processo de ensinar e aprender. Indagava-me, então, se eram os alunos que possuíam dificuldades na aprendizagem ou são os docentes que apresentam deficiências no processo de ensino. Tratava-se de uma dúvida sustentada na constatação de que os docentes do curso de graduação em Enfermagem, possuíam na sua maioria, formação na área de saúde; poucos, entretanto, revelavam possuir formação na área didático-pedagógica. Da mesma forma, ainda me perguntava sobre a possibilidade de ocorrer um somatório dessas situações. 
Em 2001 fui convidada a compor o corpo docente do Curso de Graduação de Enfermagem de uma Instituição particular de ensino superior de São Paulo. O curso, iniciado no ano 2000, era constituído de enfermeiros, de outros profissionais da área de saúde e docentes da área de humanas.

Apesar de ser a minha primeira experiência como docente em uma instituição de nível superior, resolvi aceitar o convite por achar que conseguiria fazer um bom trabalho. Iniciei, então, na disciplina de Semiologia e Semiotécnica de Enfermagem I e II.

$\mathrm{Na}$ disciplina de Semiologia e Semiotécnica de Enfermagem I o conteúdo a ser desenvolvido consistia nos instrumentos básicos de enfermagem. Por serem alunos do $1^{\circ}$. semestre do curso, e ainda sem contato com outras disciplinas específicas da enfermagem, a não ser por História da Enfermagem, era necessário que eu desenvolvesse estratégias que os auxiliassem a serem atores de sua própria aprendizagem e a verem a relação dos conteúdos com a prática profissional. Dessa forma, comecei a investigar na literatura conteúdos referentes às estratégias que pudessem ser utilizadas em sala de aula.

Passei a ministrar aulas expositivas, organizar seminários e dramatização, aplicar dinâmicas de grupo. Assim 
sendo, no decorrer desse primeiro ano, foi possível avaliar as estratégias que foram positivas e as negativas na aprendizagem dos conteúdos, avaliar a relação interpessoal que estabeleci com os alunos e as relações que surgiram entre eles próprios entre si.

No semestre seguinte, apesar da pouca experiência acumulada no ensino superior, em relação a disciplina de Semiologia e Semiotécnica de Enfermagem II, já me sentia mais segura e podia vislumbrar a possibilidade de ser uma educadora de enfermagem e uma docente que deixasse boas marcas nos alunos e não apenas uma mera transmissora de informações.

Em 2002 assumi a disciplina de Recursos Didáticos e Tecnológicos aplicados à Enfermagem I e II para $03^{\circ}$. e $4^{\circ}$. semestres, respectivamente, por ter demonstrado grande interesse nessa área do conhecimento.

A partir de então, tive a percepção de minha deficiência nessa área e me dediquei profundamente ao estudo dessa disciplina. Assim, adquiri livros e artigos voltados para o ensino superior, buscando uma base sólida de conhecimento que pudesse me auxiliar na sala de aula.

Nesse mesmo ano, fui pela primeira vez, orientadora de um projeto de Iniciação Científica tendo três alunas sob minha 
responsabilidade. Com o título "A sala de aula de um novo tempo" decidimos, por meio de pesquisa bibliográfica, analisar a aula expositiva como estratégia de ensino e, assim, compreender como ela vem se modificando, de acordo com as mudanças ocorridas no mundo, na sociedade e perante os novos paradigmas da educação (Prado, Bento, Rodrigues e Lacerda, 2002).

Ao se constatar que a aula expositiva, proclamada como estratégia dominante, sempre esteve e sempre estará presente na prática docente, independentemente da concepção pedagógica adotada, ao invés de ser rejeitada pelos professores deve ser transformada, objetivando tornar-se um eficiente instrumento do trabalho docente (Lopes, 1991).

A experiência da realização desse estudo de 2002 foi gratificante porque constatarmos que nossa prática de sala de aula tinha vindo ao encontro das propostas de uma educação renovadora na qual onde não basta somente questionar sobre a prática pedagógica, mas que se criem situações de aprendizagem que respondam melhor à diversidade dos educandos.

Ao final desse mesmo ano de 2002, percebi que era o momento para escrever meu projeto de pesquisa e tentar uma vaga no Programa de Doutorado da Escola de Enfermagem da USP. Em 2003, ingressei neste programa, enquanto que, na 
universidade onde trabalhava assumi apenas a disciplina de Recursos Didáticos e Tecnológicos aplicados à Enfermagem I e II. Tive, então, condições de dedicar-me exclusivamente ao estudo dessa disciplina e de suas implicações com a profissão de enfermagem, o que para mim foi um considerável privilégio.

Buscando conhecer como era para o graduando de enfermagem a sua percepção do ambiente de ensino que vivenciava na universidade, orientei um projeto de Iniciação Científica, tendo novamente três alunas sob meus cuidados, intitulado "Identificando o ambiente de ensino vivenciado por alunos de um curso de graduação em Enfermagem" (Prado, Bitencourt, Ferreira e Jesus, 2003).

A população foi constituída de 50 alunos do $8^{\circ}$. semestre do curso de graduação em Enfermagem de uma Instituição particular de ensino superior em São Paulo. Para a coleta de dados foi aplicada a Escala de Likert em 30 questões sobre o ambiente de ensino.

Esse estudo permitiu-nos concluir que, para $96 \%$ dos alunos, ocorreu uma boa relação professor-aluno favorecendo a disciplina na sala de aula; $94 \%$ declararam que os conteúdos foram apresentados de maneira clara e compreensível; 70\% apontaram que os professores diversificaram a utilização dos recursos 
audiovisuais e forneceram material de apoio (apostilas), facilitando a aprendizagem; $68 \%$ concordaram que o comportamento do grupo cooperou para sua própria aprendizagem; e 92\% referiram estarem informados de como seriam avaliados.

Os dados percentuais revelaram, então, que o ambiente vivenciado pelos alunos do Curso de Graduação em Enfermagem foi, por eles mesmos identificado como satisfatório, sob os aspectos analisados.

Orientei também dois Trabalhos de Conclusão de Curso (TCC) os quais me deram grandes chances de aprendizagem no sentido de saber conduzir um trabalho de pesquisa científica. Seus títulos eram: "Identificando o conhecimento do graduando de enfermagem sobre a comunicação não-verbal" (Prado, Fonseca e Sodré, 2003) e "Identificando a fonte e a clareza das orientações dadas aos idosos sobre medicações" (Prado, Patrício e Pita, 2003).

Em 2004, no curso de graduação dessa mesma universidade, continuei na disciplina de Recursos Didáticos e Tecnológicos aplicados à Enfermagem I e II e ingressei no seu Programa de Pós-Graduação ministrando a disciplina Didática no Contexto da Enfermagem. Eram cursos do nível de especialização em Enfermagem na área de Unidade de Tratamento Intensivo 
(UTI), de Pronto-Socorro (PS), de Centro Cirúrgico (CC). No ano de 2005 assumi ainda aulas no curso de Saúde Mental e Psiquiátrica.

De igual modo, neste ano, permaneci na disciplina de Recursos Didáticos e Tecnológicos aplicados à Enfermagem I e II, que passou então a se chamar Didática em Enfermagem e Processo Educativo em Enfermagem.

Atualmente estou também desempenhando a docência em outra Instituição particular de ensino superior de São Paulo na disciplina de Educação em Saúde.

Tenho buscado na pedagogia respostas para minhas limitações e, dessa maneira, descoberto caminhos mais adequados para desenvolver as responsabilidades docentes. Fui, então, compreendendo que ensinar é um compromisso de vida, com a cultura, uma paixão pelo saber e, mais do que tudo, um gostar das interações humanas.

Assim, nessa trajetória prática da docência, enriquecida com as tarefas das orientações acadêmicas e no convívio com outros docentes, acreditava que os professores enfermeiros e de outras áreas da saúde agiam de formas distintas por possuírem diferentes formações profissionais. 
Da mesma forma, na medida em que ia estabelecendo uma relação face a face com os colegas docentes enfermeiros e das diferentes áreas de formação acadêmica, neste cenário social, tive condições de acompanhar o agir dos docentes e o desenvolvimento de seus projetos.

Nesta ótica, é necessário que o docente se sinta responsável por colaborar com a formação do profissional, e não apenas ministrar uma disciplina de forma isolada e desintegrada das demais disciplinas, destacando aqui a real importância da interdisciplinaridade na formação do futuro profissional.

Os docentes desse Curso de Enfermagem no qual trabalhava possuíam uma diversificada trajetória profissional. Havia desde iniciantes na área da docência, como eu, por exemplo, até professores com 25 anos de experiência. Apesar dessa heterogeneidade, havia um denominador comum que nos unia e nos levava a discutir questões relativas a conteúdos, estratégias, formas mais adequadas de avaliação, relação professor-aluno compartilhando com eles questões do dia-a-dia da sala de aula.

Não sem motivo, pois, a minha situação biográfica até então acumulada, tenho refletido sobre o agir docente e sobre os motivos que os levam a agir e a elaborara seus projetos. Então, alguns questionamentos surgiram dentro de mim: 
- Pelo fato de os docentes enfermeiros e os de outras áreas da saúde possuírem formações diferentes, teriam eles a mesma reciprocidade na forma de agir?

- E quanto a seus projetos? Teriam a mesma intencionalidade?

- Existe uma relação de intersubjetividade entre esses sujeitos?

- As tipificações convergem ou divergem?

Senti, então, a necessidade e a importância de compreender o fenômeno das ações e das intenções dos docentes enfermeiros e dos docentes de outras áreas de saúde no exercício da docência de um curso de graduação enfermagem.

Com a finalidade de situar o leitor no contexto que se relaciona com o tema deste estudo, optei por apresentar alguns fundamentos teóricos que sustentam o processo educativo no ensino superior e a docência na Enfermagem. 


\section{A EDUCAÇÃO NO ENSINO SUPERIOR}

O vocábulo "fenômeno", considerado neste momento, refere-se ao objeto do conhecimento que se quer esclarecer. No nosso caso, então, para uma melhor compreensão do fenômeno a ser desvelado é preciso trazer conceitos como educação, universidade e situar os atores que transitam por esses palcos da nossa discussão.

De acordo com Chauí (2003), "Educação significa um movimento de transformação interna daquele que passa de um suposto saber (ou da ignorância) ao saber propriamente dito (ou à compreensão de si, dos outros, da realidade, da cultura acumulada e da cultura no seu presente ou se fazendo)".

Acreditando que a educação é essencialmente transformadora de práticas e de consciência, a educação moderna deve possibilitar a habilidade de criar, exercer novas funções, deve ser desafiadora e romper com o tradicionalismo (Waldow, 1993).

Porém, ressalta Pinto (2002), "o que precisamos ter claro é que mudar não significa excluir o antigo, mas aperfeiçoá-lo. O novo não ameaça 0 velho ou elimina-o mas, gera o crescimento". 
Moran (2002), por sua vez, acrescenta que a educação tem o papel de contribuir para que educadores e educandos transformem suas vidas em processos permanentes de aprendizagem. Diz esse autor:

\begin{abstract}
É ajudar os educandos na construção de sua identidade, do seu caminho pessoal e profissional - de seu projeto de vida, no desenvolvimento das habilidades de compreensão, emoção, e comunicação que Ihes permitam encontrar seus espaços pessoais, sociais e profissionais e tornar-se cidadãos realizados e produtivos. (Moran, 2002)

Portanto, preparar o novo homem para o milênio que inicia é pensar a educação de uma nova forma; é vê-la com um novo olhar; é perceber e acreditar na possibilidade de transformar imprescindível para quem deseja encontrar as melhores soluções
\end{abstract} informações em conhecimento, sendo este um elemento para os desafios do mundo moderno (Antunes, 2001).

A literatura específica sobre educação tem destacado que as mentes humanas não são iguais e que existem muitas e diferentes maneiras de conhecer o mundo e pensar sobre ele. Gardner (1994), por exemplo, declara que as pessoas possuem forças e fraquezas diferentes, e é um erro pensar que existe uma única inteligência, em torno da qual todas elas podem ser comparadas.

Fica evidente, portanto, que reconhecer essa diversidade é acreditar ser necessário e possível desenvolver uma 
educação mais personalizada a qual supõe aproveitar uma série de interesses individuais e capacidades humanas.

Então, com base nessa evidência e partindo do pressuposto de que duas pessoas não podem exibir as mesmas inteligências nas mesmas proporções - pois estas recebem influências de fatores genéticos, do ambiente com suas interações está legitimado um desafio para o nosso sistema educacional.

Segundo Demo (2002), a proposta instrucionista, baseada no ensino, na instrução e no treinamento é que se faz presente no contexto educativo brasileiro. Adverte, porém, que isso não é educação. Esta realmente acontece quando vem acompanhada de questionamentos e análises. Para tanto, novos paradigmas e novas práticas de ensino devem ter seus alicerces assentados em situações-problema e na ativação dos aprendizes. "As situações-problema caracterizam-se por recortes de um domínio complexo, cuja realização implica mobilizar recursos e tomar decisões" (Perrenoud, 2002).

Nesse sentido, a abordagem atual por problemas deverá ser aquela em que o educando é colocado frente a situações próximas daquelas que irá encontrar na sua futura realidade profissional e construir seus saberes a partir dessas 
situações, no período de formação acadêmica e nas oportunidades de educação continuada.

Com base nessas afirmações de caráter conceitual, se faz necessário analisar o conceito de universidade para que possamos entender o contexto do presente estudo. Ela é descrita por Pimenta e Anastasiou (2002), como um serviço de educação que se concretiza pela ação docente e pela pesquisa com a intenção de criar, desenvolver e transmitir, de forma crítica, a ciência, a técnica e a cultura. Tem a missão de preparar os futuros profissionais para a aplicação dos conhecimentos científicos e para o desenvolvimento de suas habilidades, além de fortalecer os desenvolvimentos culturais, sociais e econômicos das sociedades.

Uma análise acurada da educação no século XXI, apresentada na Conferência Mundial de Ensino Superior, promovida pela Organização da Nações Unidas para a Educação, Ciência e Cultura (UNESCO), em Paris no ano de 1998, mostrou a grande preocupação com a qualidade do ensino superior, revelando-se um consenso a necessidade de melhorar o ensino. Nesse evento, severa crítica foi feita ao modelo vigente, o qual se apresenta desprovido de criatividade e arcaico sob diversos aspectos.

A conferência destacou que os estudantes devem ser considerados como os principais protagonistas do processo de 
ensino-aprendizagem, merecendo um tratamento prioritário, individualizado e diferenciado. Foi sugerido ainda o emprego de novas tecnologias da informação com vistas à renovação no ensino superior, mediante a utilização de formas criativas, flexíveis e abertas. De igual modo, afirmou a necessidade urgente de melhorar a preparação e a remuneração do corpo docente.

Desse encontro surgiu o consenso de que, para a educação superior em nível mundial, é preciso que haja uma valorização da diversificação como meio para reforçar a igualdade de oportunidades e o emprego de métodos educativos inovadores, permitindo o pensamento crítico e a expansão da criatividade (Niskier, 2001).

Um outro aspecto tem sido muito enfatizado pelos organismos internacionais que discutem o ensino superior. Declara Chauí (2003):

É que a sociedade do conhecimento é inseparável da velocidade, isto, é, existe uma acentuada redução do tempo entre a aquisição de um conhecimento e sua aplicação tecnológica, a ponto dessa aplicação acabar determinando o conteúdo da própria investigação científica.

Nesse sentido, vivenciamos uma verdadeira explosão do conhecimento tanto no aspecto qualitativo quanto no quantitativo. 
Tal fenômeno reforça a idéia de que, diante de um mundo globalizado e em transformação constante, a educação continuada ou permanente é indispensável na vida dos indivíduos; somente com ela é possível adaptar-se às mudanças frenéticas e incessantes que permeiam o mundo do trabalho. "É quando a educação deixa de ser preparação para a vida e se torna educação durante toda a vida" (Chauí, 2003).

De acordo com Paulo Renato Souza, ex-ministro da Educação, com o advento da tecnologia da informação, todo o planeta vivencia um momento de rápidas e contínuas transformações gerando a sociedade do conhecimento, na qual a informação é o motor do desenvolvimento e está caracterizada pela importância crescente do saber e pelo desenvolvimento da capacidade intelectual (Souza, 2001).

Demo (2002) enfatiza que transmitir informação ainda é algo importante para a sociedade, mas que o mundo eletrônico faz isso com mais graça e com mais disponibilidade que o professor. Este, se faz absolutamente importante à medida que é necessário para o processo reconstrutivo do educando.

Esta mudança no cenário global transformou o conceito de ensinar e para atender a demanda da era do 
conhecimento destaca-se a tecnologia na educação exigindo assim um novo perfil dos docentes.

A renovação que vem ocorrendo na área educacional aponta a valorização de um conjunto de habilidades como autonomia de pensamento e ação, capacidade de integrar novos elementos a antigos nas diversas áreas do conhecimento, instituindo-se novos alicerces do ensino superior, onde o principal deles é o ensino por competências. Para Perrenoud (2002), "competência em educação é mobilizar um conjunto de saberes para solucionar com eficácia uma série de situações".

Em outro estudo, o mesmo Perrenoud (1999), ao considerar as competências em educação as define como sendo a capacidade de mobilizar um conjunto de saberes para solucionar com eficácia uma série de situações.

Rios (2001), por seu lado, enfatiza que competência significa saber fazer bem. Afirma que saber fazer bem tem uma dimensão técnica, a do saber e a do saber fazer que vai desde o domínio dos conteúdos os quais o sujeito necessita para desenvolver o seu papel, até àquilo que a sociedade espera dele em sintonia com o domínio das técnicas; ou seja, o fazer das estratégias que o sustente na sua prática. 
Todavia, mais do que isso, é preciso saber fazer bem indicando tanto a dimensão técnica como a dimensão política - e esse bem, delineado em um contexto histórico, é determinado pelas necessidades definidas pelos cidadãos de uma determinada sociedade e em um determinado tempo. Essa idéia de bem está vinculada a uma dimensão técnica e moral permeada por uma dimensão ética que define e organiza os saberes para a sociedade.

Dentro desse novo cenário de onde o docente explora as competências individuais dos alunos, ele passa a ter a responsabilidade de conhecê-los melhor e detectar as possibilidades de cada um. Portanto, a visão padronizada, unitária e quantitativa de inteligência, como se fosse possível medi-la, deve ser rejeitada quando comparada aos novos conceitos de inteligência (Ramos, 1997).

Como cita Martins (2003),

Um bom educador do terceiro milênio será marcado pela informação e pelo conhecimento tecnológico. Além de competência, habilidade interpessoal e equilíbrio emocional este tem a consciência de que o respeito às diferenças está acima de toda pedagogia.

A dinâmica que se verifica no campo da educação não pode aceitar que o professor fique parado no tempo, que rejeite mudanças, que não acredite na eficácia das novas tecnologias. A forte tendência à inércia humana, que leva a 
continuar agindo sempre do mesmo modo, a resistência dos docentes frente a novas possibilidades de ensino, são condicionantes que dificultam o processo de ensino-aprendizagem.

Mais importante do que apenas informar, Silva (2000) defende que o mestre precisa perder seu senso de superioridade cultural, fazer da sala de aula um ambiente de aprendizagem coletiva, observar a necessidade de estar continuamente ligado à evolução do conhecimento, em sua especialidade e no mundo exterior, ter capacidade de analisar e relacionar variáveis e fatos, de forma superior à do aluno e fazer continuamente uma reflexão crítica.

A essa perspectiva Pinto (2002) acrescenta a pertinência de valorizar os potenciais do ser humano e buscar capacitá-lo a desenvolver estas potencialidades. São fatores que fazem parte de uma nova proposta que enxerga a educação com uma visão holística, a qual procura educar a pessoa integrada ao seu meio social e ambiental. Em suma, educar trabalhando todas as áreas, corpo, mente e espírito. Trata-se de uma educação que desperta e desenvolve a razão e a intuição, a sensação e o sentimento; enfim, busca o equilíbrio entre o lado direito e esquerdo do cérebro. 
Para tanto, a prática docente deve ser alicerçada em um projeto político pedagógico que, segundo Masetto (2003), ...

organiza e consolida a programação das atividades acadêmicas de ensino, pesquisa e extensão, dos cursos de graduação, especialização e pós-graduação, bem como orienta a contratação de docentes e funcionários, 0 aperfeiçoamento e desenvolvimento deles, o processo de seleção dos candidatos e a infra-estrutura acadêmica, administrativa e pedagógica.

Ainda Masetto (2003) declara que é um projeto político porque estabelece e dá sentido ao compromisso social que a instituição de ensino superior assume com a formação de profissionais e de pesquisadores cidadãos que, na sociedade em que vivem, desenvolvem sua participação e seu compromisso com a transformação da qualidade de vida dessa mesma sociedade.

Pimenta (2002) reforça que também "é um projeto pedagógico porque discute o ensinar e o aprender num processo de formação, de construção de cidadania, e não apenas de preparação técnica para uma ocupação temporal".

$\mathrm{Na}$ perspectiva de Vasconcellos (2002), o projeto pedagógico

É entendido como a sistematização, nunca definitiva, de um processo de planejamento participativo, que se aperfeiçoa e se objetiva na caminhada, que define claramente o tipo de ação educativa que se quer realizar, a partir de um posicionamento quanto à sua intencionalidade e de uma leitura da realidade.

Para Pimenta (2002), o projeto é 
fundamentalmente coletivo pois possibilita e exige que seus constituintes participem do processo de análise, discussão e tomada de decisão quanto aos rumos que, consciente e criticamente, definem como necessários e possíveis à instituição universitária .

Com base no testemunho desses educadores, é necessário que se construa um projeto político pedagógico viável e que seja assumido na prática por todos; nele a coordenação passa a ter o papel de administrar sua elaboração e consecução em sintonia com professores, alunos, funcionários e sociedade.

A construção coletiva ajuda todo o grupo a superar o imobilismo e a resistência às mudanças. Isso porque, permitir que cada elemento do processo participe das tomadas de decisão é uma forma de fazê-los assumir as responsabilidades que the cabem.

Em um projeto político pedagógico articulam-se professores, disciplinas, alunos, horários de disciplinas e de outras atividades acadêmicas, carga horária, descrição dos espaços e recursos existentes na instituição, a formação dos professores e sua titulação, bem como as atividades de interação com a comunidade. É um processo dinâmico de ação e reflexão que procura uma articulação entre ideal e o real, na tentativa de minimizar a distância que separa o que a educação pretende e o que a realidade permite. 
São novos paradigmas que geram necessidades de mudança de postura por parte dos componentes do processo de ensinar e de aprender. São necessidades que podem causar um certo receio aos educadores que se sentem seguros porque se acham donos do saber. Essas novas propostas permitem que vivenciemos um momento absolutamente admirável na História da Educação em que novos pensadores da educação, a exemplo do francês Edgar Morin, do suíço Philippe Perrenoud, dos espanhóis César Coll e Fernando Hernández, do português António Nóvoa e do colombiano Bernardo Toro vêm trazendo significativas contribuições no processo de renovação dos métodos educativos das escolas.

Desse modo, se faz necessária uma consciência maior dos educadores, no sentido de estarem questionando se, de fato, têm dado a devida atenção ao desenvolvimento de suas próprias potencialidades latentes, ou se estão mais preocupados apenas com a transmissão de informação de forma mecânica e automatizada.

Após estas considerações sobre a educação no ensino superior, segue, no próximo capitulo, o referencial teórico sobre a prática docente no ensino de enfermagem e os estudos que vêm sendo realizados nessa área. 
Em relação ao ensino da Enfermagem, o Parecer $\mathrm{N}^{0}$ : CNE/CES 1.133/2001 do Ministério da Educação e do Conselho Nacional de Educação salienta que um dos princípios das Diretrizes Curriculares é

Incentivar uma sólida formação geral, necessária
para que o futuro graduado possa vir a superar os
desafios de renovadas condições de exercício profissional
e de produção de conhecimento, permitindo variados tipos
de formação e habilitações diferenciadas em um mesmo
programa; estimular práticas de estudo independente,
visando uma progressiva autonomia intelectual e
profissional; encorajar o reconhecimento de habilidades e
competências adquiridas fora do ambiente escolar;
fortalecer a articulação da teoria com a prática (DOU,
2001).

A Comissão da Câmara de Educação do Ensino Superior do Conselho Nacional de Educação, ainda mediante esse mesmo parecer, reforçou nas Diretrizes Curriculares dos Cursos de Graduação em Saúde que deve haver uma articulação entre a Educação Superior e a Saúde, tendo por objetivo a formação geral e específica dos egressos/profissionais com ênfase na promoção, prevenção, recuperação e reabilitação da saúde. Da mesma maneira indica as competências comuns gerais para esse perfil de formação contemporânea dentro de referências nacionais e internacionais de qualidade. 
Nesse sentido, as Diretrizes Curriculares traçam o seguinte perfil do formando egresso/profissional:

Enfermeiro, com formação generalista, humanista, crítica e reflexiva. Profissional qualificado para o exercício de Enfermagem, com base no rigor científico e intelectual e pautado em princípios éticos. Capaz de reconhecer e intervir sobre os problemas/situações de saúde-doença mais prevalentes no perfil epidemiológico nacional, com ênfase na sua região de atuação, identificando as dimensões bio-psico-sociais dos seus determinantes. Capacitado a atuar, com senso de responsabilidade social e compromisso com a cidadania, como promotor da saúde integral do ser humano.

Sendo esse o perfil esperado dos graduandos em Enfermagem, cabe então indagar se os docentes sentem-se capacitados para desempenhar suas funções. Desse modo, é necessário que haja uma reflexão contínua, por parte dos docentes, para tornar sua prática coerente com as renovações em andamento no sistema educativo nacional.

Para responder a essa minha indagação, busquei pesquisas na área de enfermagem que tiveram como foco de estudo a análise da prática dos docentes de enfermagem no contexto universitário, como podem ser observadas nas referências que se seguem.

Silva (1997), em sua dissertação de mestrado, analisou o comportamento docente no ensino de graduação em 
Enfermagem de acordo com a percepção dos alunos. A autora pode concluir que há pluralidade de comportamentos docentes, predominando professores preocupados com os conteúdos, métodos e técnicas, com características das concepções tradicional, comportamental e cognitivista. Com menor freqüência revelaram comportamentos mais críticos, relacionados com a tendência sociocultural, bem como comportamentos afetivos, comprometidos com uma tendência humanista.

No estudo de Arantes (1999), vemos que seu objetivo foi refletir sobre as possibilidades de transformações do ensino de saúde coletiva na enfermagem. Analisou, então, as concepções e percepções dos docentes, alunos e egressos de um curso de graduação em enfermagem e apontou a interdisciplinaridade como um caminho a ser percorrido, tanto para solucionar a fragmentação no ensino, como para articular os diversos conhecimentos no campo da saúde coletiva.

Rocha (1999), por sua vez, procurou apreender os significados atribuídos à comunicação docente-discente no ensino de enfermagem. Sua pesquisa foi desenvolvida como um estudo de campo das interações entre docente e alunos em sala de aula. É possível afirmar, a partir dos resultados obtidos, que existem comportamentos comunicativos verbais e não verbais que podem 
motivar o aluno a aprender, bem como a existência de coerência entre o verbal e não-verbal. Os sujeitos pesquisados manifestaram suas opiniões referindo como aspectos facilitadores do aprendizado: a dinâmica realizada em aula, a boa comunicação professor-aluno e o conteúdo relevante; como aspectos dificultadores: o tempo reduzido para a matéria, a inibição de alguns alunos e a falta de interesse pelo tema.

Essa mesma autora declara que os resultados desse estudo nos fazem acreditar que a sala de aula pode ser um lugar de demonstração de emoção e descontração, de afetividade e respeito pelo outro, onde as diferenças individuais devem ser reconhecidas, respeitadas e valorizadas, pois estimulam a construção do conhecimento.

Magalhães (2000) ao estudar o ensino superior em enfermagem e o desafio da mudança na busca de referências de um novo modelo de formação, pretendeu caracterizar os aspectos significantes do processo de convivência de um grupo docente com os desafios de uma nova graduação.

Pôde, então, detectar que emergem representações concernentes a uma graduação conceitualmente transformada no âmbito dos conteúdos e das relações pedagógicas; uma graduação que vai ao encontro de uma sintonia seletiva com o mercado de 
trabalho e que deixa evidente bases teóricas para um processo de mudança a partir de pressupostos, requisitos e etapas de implementação já delineadas pelo grupo; fatores esses capazes, inclusive, de abrigar novas expressões de ser docente e de ser discente. Entretanto, esses conteúdos ideativos projetam gestos e estratégias de enfrentamento ainda tímidos, aparentando uma fragilidade operacional frente às diretrizes de uma graduação que deva estar em sintonia tanto com os dispositivos legais quanto com os atuais requisitos do mercado de trabalho.

Peres (2001), em sua tese de doutorado, buscou desvelar, segundo a percepção dos enfermeiros docentes, o significado da inserção da informática no ensino de enfermagem. O cenário desvelado permitiu compreender que o docente apresenta diferentes graus de interesse pelas novas tecnologias com vistas à inserção da informática no ensino de enfermagem. A adoção da informática, segundo essa autora, vislumbra projetos fundamentados em novos modelos pedagógicos que possibilitem aprendizado auto-instrucional e individualizado, numa perspectiva de formar enfermeiros críticos, reflexivos e competentes no que diz respeito a essas tecnologias.

Constatou também que esses projetos têm como fontes de intuição e de idealização os conhecimentos armazenados 
e as experiências educacionais adquiridas pelo docente no seu mundo-vida; porém, a tomada de decisão ou escolha desses projetos ocorre livremente num processo de reflexão e de refinamento sobre as alternativas favoráveis e desfavoráveis, geradas a partir do contexto social e da situação biográfica de cada docente.

Temos ainda a dissertação de mestrado de Esperidião (2001), que objetivou identificar e analisar as percepções e os sentimentos do aluno do curso de graduação em Enfermagem, relacionados à sua formação como pessoa e como profissional.

Os resultados revelaram que os alunos percebem a formação acadêmica centrada em conhecimentos técnicocientíficos, voltados especialmente ao atendimento das necessidades daqueles que vão ser assistidos; sem considerar a pessoa que os assiste, mas sinalizam que a trajetória acadêmica é permeada de vários sentimentos que vão aparecendo em função das experiências ocorridas ao longo dela. Da mesma forma, ficou evidenciado que, em algumas situações específicas, principalmente naquelas ligadas à área de saúde mental, o aluno tem tido a oportunidade de expressar e lidar com seus próprios sentimentos.

A autora considera que sua pesquisa oferece elementos importantes a serem repensados pelas Escolas de 
Enfermagem, visando a formação do aluno como pessoa integral e integrada em suas ações.

Ohl (2002), em sua tese de doutorado, procurou compreender a percepção do docente da disciplina de Enfermagem na Saúde do Adulto institucionalizado quanto ao desenvolvimento de sua competência interpessoal na relação estabelecida com o aluno. Descobriu que a conscientização das professoras acontece quando, ao relatarem suas experiências de relação com os alunos, reconhecem ter competências bem como limitações no que diz respeito ao desempenho de seu papel como educadoras de Enfermagem.

Essa constatação possibilita o entendimento de que as docentes nesta disciplina necessitam aprofundar a reflexão e o conhecimento à respeito do desenvolvimento de suas competências. Isso porque precisa levar em conta que o aluno que está aprendendo é um Ser-adulto em formação, tanto em relação aos aspectos técnicos-didáticos, como também aos aspectos relacionais. Dessa forma, o aluno pode conhecer de forma concreta como o seu Ser-docente se manifesta e, assim, estar mais bem preparadas para enfrentar as dificuldades de relacionamento vivenciadas no processo de ensino-aprendizagem na Enfermagem. 
Ainda considera muito importante que se criem oportunidades para discussão da prática docente como um dos caminhos para enfrentar as dificuldades que emergem no processo de ensinar e de aprender.

O estudo de doutorado de Cavalcanti (2003) denominava-se "Humanização no processo de formação de profissionais de saúde: experiências dos alunos do curso de graduação em enfermagem". O título traz implícito um dos seus objetivos que era conhecer as percepções de alunos de graduação em Enfermagem sobre as experiências vividas durante o período de formação, por eles consideradas positivas ou negativas. Um outro objetivo consistia em conhecer as estratégias adotadas pelo professor, como agente facilitador/dificultador do processo de ensinar e aprender. Pretendeu-se, ainda, subsidiar o aprimoramento do processo de cuidar do cuidador em formação, como parte de um projeto de humanização das relações entre quem cuida e quem é cuidado.

Os depoimentos revelam os diferentes significados atribuídos à humanização, contemplando distintas dimensões: as estratégias facilitadoras e dificultadoras da aprendizagem e as necessidades dos alunos que foram ou não atendidas pelo docente. Os relatos trazem aspectos contundentes e ambíguos das 
experiências vividas pelos discentes que assinalam pontos que deveriam ser respeitados/resguardados na formação dos alunos de enfermagem e de outros profissionais de saúde.

Nimtz (2003) nos apresenta sua contribuição com seu estudo que teve o objetivo de identificar as percepções dos professores que atuam em disciplinas de Administração em Enfermagem. Propôs-se também a problematizar os significados atribuídos à competência docente, visando sugerir intervenções que favoreçam propostas de capacitação para o ensino do gerenciamento, compatíveis com a política de ensino e com as atuais Diretrizes Curriculares.

A autora recomenda que as Instituições de ensino estabeleçam uma política de desenvolvimento de recursos humanos que privilegie o processo de capacitação docente, indo ao encontro das Políticas de Educação e das Diretrizes Curriculares Nacionais dos Cursos de Graduação em Enfermagem. Tal política oferece oportunidades concretas para que o desenvolvimento do corpo docente impulsione transformações rumo a uma educação emancipada que incorpore valores éticos e políticos, voltados para a solidariedade e para o humanismo.

Campoy (2003), em sua pesquisa, teve a intenção de compreender o processo de ensino-aprendizagem segundo a 
perspectiva do professor e do aluno os quais vivenciaram a disciplina de enfermagem psiquiátrica e saúde mental. Sua conclusões permitiram conhecer o "típico vivido" do professor e do aluno. Do professor que quer um aluno compromissado, reflexivo, competente e que veja o outro como pessoa; e do aluno que deseja aprender a lidar com ser humano em sua saúde física e mental, com competência.

Braga (2004), em sua tese de doutorado, teve em mente caracterizar referenciais de competências comunicativas interpessoais e propor bases teórico-metodológicas para o aprendizado da comunicação interpessoal no ensino de Enfermagem junto a professores de Enfermagem desse curso.

Os resultados obtidos mostram que a eficácia da comunicação supõe uma relação estabelecida em função do objetivo desejado pelo comunicador. A competência de quem comunica pressupõe conhecimentos básicos do processo de comunicação, consciência do verbal e do não-verbal nas interações, atuação clara e objetiva, promoção do autoconhecimento e, conseqüentemente, a possibilidade de uma vida mais autêntica.

Os sujeitos pesquisados relatam que a expressão da competência comunicativa está, necessariamente, no vivenciar o cotidiano profissional e pessoal. Isso significa ouvir o outro, prestar 
atenção na comunicação não-verbal, validar a compreensão das mensagens, ser capaz de eliminar as barreiras impostas à comunicação, demonstrar afetividade e investir no autoconhecimento. Por sua vez, o desenvolvimento da competência comunicativa verifica-se pelo estímulo recebido desde a graduação, pelas leituras de aprofundamento do tema, pela prática profissional e realização de pesquisas e publicações na área. $O$ ganho alcançado, relata a autora, resulta em relações profissionais e pessoais mais significativas, maior autoconsciência e aceitação das diferenças do ouro, ampliação dos caminhos do ensino e da pesquisa e conquista de um bem-estar.

Não sem razão, pois, esses resultados nos permitem considerar que a competência em comunicação interpessoal, é uma habilidade fundamental a ser adquirida pelo enfermeiro, sabendo que esta Ihe possibilitará um cuidar com qualidade.

Soares (2004) buscou compreender a ação do docente segundo a perspectiva do professor e do aluno que vivenciam o curso de graduação em enfermagem. Refere que o tipo vivido compreendido para o docente, pressupõe um docente envolvido com seu aluno, que se preocupa com seu modo de interagir no processo ensino-aprendizagem. Ao mesmo tempo trata-se de um docente preocupado com sua capacitação e 
formação, acreditando no ensino pautado na relação teóricoprática. Para o aluno, o docente também apresenta envolvimento com o aluno, tem conhecimento da disciplina básica e experiência na área, assim como facilidade no processo de transmitir conhecimento.

Um outro estudo nos leva a Santos (2005), que procurou desvelar, também, segundo a percepção de professores e alunos, as suas expectativas frente a um Curso de Graduação em Enfermagem de uma universidade particular da cidade de São Paulo. Pôde compreender, então, que o docente de enfermagem é aquele que tem como expectativa um aluno com capacidades técnicas e científicas a serem desenvolvidas, sendo necessário superar suas próprias dificuldades para o aprendizado caso exista um projeto pedagógico que caminhe nessa direção.

O aluno é aquele que vem em busca de conhecimentos técnicos e científicos para aplicá-los no cuidado humano, adquirindo atributos que Ihes dão oportunidade de inserirse no mercado de trabalho. Percebe o professor como quem tem experiências profissionais e capacidades técnicas e científicas que o auxiliam na sua aprendizagem.

Todas essa considerações aqui registradas dão a entender que estudos indicam convergências quando referem a 
ação dos docentes nos cursos de enfermagem. È uma constatação que vem ao encontro do que Martins (2002) destaca como alguns princípios que devem nortear o educador do milênio: "O professor do século XXI é aquele que, além da competência, habilidade interpessoal, equilíbrio emocional, tem a consciência de que mais importante do que o desenvolvimento cognitivo é o desenvolvimento humano e que o respeito às diferenças está acima de toda pedagogia".

Nesse novo papel, a ênfase recai sobre o mediar a aprendizagem. É um papel que requer do docente, entre outras coisas, a articulação de conceitos e princípios das ciências da aprendizagem, valores humanistas, bem como habilidades de planejamento e mediação de processos de aprendizagem voltados para o desenvolvimento de competências e o aprender a aprender.

Os docentes dos tempos atuais buscam formar enfermeiros com capacidade de reconhecer e analisar seu papel como profissional, atuando como enfermeiro-cidadão na relação com o outro, como agente de mudança para uma sociedade melhor, capazes de formular e implementar ações educativas ao indivíduo, família, comunidade e trabalhadores de enfermagem.

Porém, foi interessante notar que em todas as pesquisas trazidas até aqui, o universo pesquisado abrangia apenas 
alunos de enfermagem e docentes enfermeiros. Nenhuma avaliação dos docentes com formação em áreas diferentes da Enfermagem. Esse dado significou que docentes com outra formação constituem um segmento esquecido nas pesquisas de enfermagem.

Da mesma forma que os docentes enfermeiros, é inegável que esses outros profissionais mereçam uma análise sobre suas práticas. Devemos lembrar-nos que eles também fazem parte de um corpo docente responsável pela formação do profissional enfermeiro. Razão mais do que suficiente para justificar a importância de realizar este trabalho.

Um curso de graduação em Enfermagem, desenvolvido por um corpo docente multiprofissional, tendo como base a interdisciplinaridade, forçosamente irá convergir para melhor aprimoramento dos formandos. Por outro lado, uma formação de caráter interdisciplinar implica, no dizer de Krasilchick (1998), superar e renunciar ao isolacionismo acadêmico, ao conservadorismo disciplinar e ao abandono das vaidades pessoais. 


\section{APRESENTANDO O REFERENCIAL METODOLÓGICO}

Devido à natureza das minhas inquietações já manifestadas neste estudo, iniciei o Doutorado cursando disciplinas que pudessem auxiliar-me na construção deste projeto de trabalho.

Dessa forma, fiz a opção pelas disciplinas Metodologia do Ensino Superior - na Faculdade de Educação da USP - e Educação em Enfermagem: os Princípios Constitutivos da sua Identidade e Perspectivas do Ensino de Enfermagem - na Escola de Enfermagem da USP.

Quando o objetivo pretendido foi sendo mais claramente delimitado, tive que buscar uma metodologia que pudesse conduzir a sua consecução.

Se Merighi (2002), advoga que a realidade social não se esgota nas informações quantitativas, minha trajetória metodológica, por conseguinte, iria ser traçada por meio da pesquisa qualitativa por compreender uma abordagem de pesquisa que, no dizer de Gualda (1995), enfatiza a importância de se conhecer, compreender e interpretar a natureza das situações e eventos quer sejam eles, passados ou presentes. 
Assim, após entrar em contato com os diferentes métodos de pesquisa qualitativa na disciplina Pesquisa Qualitativa em Enfermagem, escolhi o campo da fenomenologia devido à congruência entre seus pressupostos e o fenômeno a ser desvelado neste estudo.

Fui buscar as disciplinas Pesquisa Fenomenológica

em Enfermagem e Seminários Avançados de Pesquisa Fenomenológica em Enfermagem, as quais me ajudaram a compreender esse referencial.

Na verdade, a fenomenologia permite ao pesquisador compreender um fenômeno em sua essência, busca as experiências vividas pelos sujeitos, a verdade e as pessoas. Nela, o pesquisador interroga como é o fenômeno para seus sujeitos partindo do seu próprio mundo-vida.

Então, reflete acerca do sentido que esse fenômeno tem para si mesmo e para aqueles com quem compartilha o mundo vivido (Capalbo, 1998).

O movimento fenomenológico nasceu da crença de que o comportamento das pessoas não pode ser controlado, aceita a experiência na forma que existe na consciência do indivíduo 
(Gualda, 1995). Teve seu início com Edmund Husserl, no começo do século XX como um movimento da filosofia.

A palavra "fenomenologia" deriva de duas expressões gregas: "phainomenon" (fenômeno) - aquilo que se mostra para si mesmo; e "logos"- discurso esclarecedor. Assim, entende-se a fenomenologia como o discurso esclarecedor daquilo que se mostra a si mesmo.

A fenomenologia representa o estudo dos significados, das essências articuladas no discurso do sujeito, através do qual o fenômeno vai se mostrar. É a possibilidade de olhar as coisas como elas se manifestam (Spíndola, 1997).

Nesta metodologia o pesquisador não tem um problema para pesquisar. Tem dúvidas sobre as quais interroga. Ao interrogar, constrói uma trajetória pela qual caminha em direção ao fenômeno, onde o sujeito experiência a situação (Gualda, 1995).

O pesquisador procura "desvelar"o fenômeno. Cabe aqui definir fenômeno como tudo que se manifesta ou se deSvela ao sujeito que o interroga (Spíndola, 1997).

Este revela que a fenomenologia

Coloca em evidência o homem, suas relações com o mundo e a correlação entre eles (um não existindo sem o 
outro), instaurando a atitude dialogal e do acolhimento do outro em suas opiniões, idéias e sentimentos, procurando colocar-se na sua perspectiva, para compreender e ver como ele vê, sente ou pensa.

O pesquisador deve esquecer suas próprias idéias eliminando suas pré-concepções, não havendo assim uma hipótese. A realidade não é negada nem afirmada, pois o objetivo é ver a coisa em si mesma (Leopardo, 2001). O pesquisador vai a campo sem uma compreensão prévia do fenômeno e sua interpretação requer uma intuição crítica.

Num enfoque inicial o fenômeno está oculto e não se mostra a menos que interrogado. O foco central da fenomenologia é descrever o fenômeno e não sua explicação. Para isso, um importante pré-requisito na fenomenologia é que não haja noções pré-concebidas, expectativas ou modelos de referência que possam guiar os pesquisadores.

Para Martins, 1992, a fenomenologia é a investigação direta e a descrição de fenômenos que são experimentados conscientemente, sem teorias para sua explicação causal, e tão livre quanto possível de pressupostos e de preconceitos.

A opção pela fenomenologia surgiu da congruência entre seus pressupostos e o fenômeno a ser desvelado neste 
estudo sendo escolhido, para esta pesquisa, o referencial filosófico de Alfred Schütz.

Indo ao encontro de um referencial filosófico na fenomenologia que me propiciasse entender dimensão social dos sujeitos deste estudo e sua relação com a própria prática docente, pude encontrar no filósofo Alfred Schütz o alicerce que viria a sustentar essas minhas inquietações. Esse referencial permite uma significação particular do vivido pelos próprios sujeitos que vivenciam o fenômeno em sua realidade social.

Esse filósofo viveu entre nasceu em 1899 na Áustria e cursou Ciências Sociais na Universidade de Viena tendo falecido em 1959. O pensamento de Schütz tem suas raízes na compreensão do mundo-vida por meio das ciências humanas.

\subsection{Descrevendo a fenomenologia de Alfred Schütz}

A fenomenologia social de Schütz tem a intenção de compreender o mundo com os outros em seus significados intersubjetivos. A estrutura desses significados se manifesta na vivência intersubjetiva das relações sociais.

Fustinoni (2000) relata que a proposta de Schütz é analisar as relações sociais com características particulares, nas 
quais as ações ocorrem de maneira consciente tendo um significado para os sujeitos desse processo.

Campoy reforça a idéia de que

Embora a pessoa seja aquele que vivencia e valoriza a sua experiência num contexto objetivo de significado, esse não é individual, pois, embora vivido singularmente por ela, na realidade social será constituído na intersubjetividade e interação entre todas as pessoas (Campoy, 2003).

Merighi, por seu lado, coloca que precisamos

direcionar nosso olhar

a partir do vivido dos sujeitos em seu cotidiano, pois são aspessoas que atuam, interagem e se compreendem dentro do chamado mundo social, que possibilitam o desenvolvimento do fenômeno, o conhecimento de sua existência transcendente a partir de uma perspectiva de ser-no-mundo Merighi (2002).

Schütz considera mundo-da-vida, mundo-dosenso-comum, mundo da vida diária e mundo cotidiano como expressões sinônimas que indicam o mundo no qual os sujeitos atribuem significados as coisas, acontecendo nas ações de suas experiências cotidianas. Trata-se de um mundo intersubjetivo experimentado pelo homem, onde os indivíduos podem atuar sobre os outros, compreendendo-os e sendo compreendidos (Schütz, 1974).

É o mundo onde eu e o outro vivenciamos nossas experiências, onde estabelecemos uma relação social. Este só pode ser compreendido a partir de uma realidade. 
Schütz questiona:

Como o eu do outro me é dado de forma significativa, tendo a impossibilidade de alguém observar as vivências da outra pessoa da mesma maneira como a outra pessoa o faz ? Se eu pudesse estar consciente de toda a experiência do outro, ele e eu seríamos a mesma pessoa (Schütz, 1974).

Assim, não há como desvincular os sujeitos do mundo social pois este é tido como o palco onde os indivíduos transitam de acordo com o tempo e espaço, com sua história e sua cultura.

No mundo social de Schütz, o homem assume uma atitude natural que é a postura que o indivíduo apresenta frente a seus problemas diários; é uma postura espontânea. Trata-se de conhecimentos transmitidos por gerações, na vida acadêmica e na sociedade como um todo, os quais direcionam os indivíduos, em situações similares, a obter melhores resultados, com mínimo esforço, almejando o sucesso e evitando conseqüências indesejáveis.

É a maneira pela qual o homem experimenta o mundo intersubjetivo, seja o mundo da vida diária, do cotidiano e particular ou o mundo do senso comum, histórico, temporal e coletivo o qual é a cena e o cenário da ação social. E como tal a intersubjetividade é a categoria fundamental da existência 
humana. Não somente atuamos nesse mundo, mas também sobre ele, e o interpretamos por meio de tipificações.

Dessa forma, para compreender a realidade, o indivíduo parte de sua situação biográfica, que é o espaço que o indivíduo ocupa na sociedade.

A história de vida dos seres humanos se dá em um determinado ambiente sócio-cultural onde são concebidos e criados constituindo assim a base de suas experiências. Schütz descreve a situação biográfica com os seguintes termos:

Situação biográfica é o modo pelo qual eu ocupo o espaço da ação, interpreto suas possibilidades e me envolvo com seus desafios e a sedimentação dessa experiência passa a ser a condição para a interpretação subseqüente de todos nossos eventos e desafios (Schütz, 1974).

A maneira com que o indivíduo interpreta o mundo é derivada do que existe de significativo na sua situação biográfica. Cada pessoa tem a especificidade da sua história alicerçada em experiências vivenciadas apenas por ela mesma. E é nesse mundo que deve agir.

Pelo caráter biográfico de sua história, o indivíduo demonstra seu conhecimento de diversas formas, podendo, então, ser considerado como a bagagem de conhecimentos que ele tem disponível, ou seja, suas experiências vividas anteriormente. 
Ele se sustenta nessas experiências que armazenou para determinar as suas ações futuras e rotineiras. Portanto, o significado que a pessoa atribui à sua ação está fortemente ligada à sua situação biográfica.

Porém, as novas situações, além de serem sustentadas por esse estoque de conhecimento, também o são pelo imaginário de seus sujeitos segundo a perspectiva de seus interesses particulares. Dessa forma, conhecer essas diferenças individuais constitui um elemento da experiência do sentido comum.

Schütz (1974), afirma que bagagem de conhecimentos "É uma estrutura sedimentada nas experiências subjetivas prévias do indivíduo, adquiridas ao longo de sua vida, através de experiências vivenciadas ou que a ele foram comunicadas por outra pessoa."

Um outro conceito importante na teoria desse mesmo filósofo diz respeito à ação humana que é considerada uma conduta humana direcionada para a realização de um determinado fim. Tem origem na consciência dos sujeitos; é consciente e voluntária, e desencadeia um comportamento intencional. 
É a execução do ato que foi projetado, sendo considerada uma atividade espontânea orientada para o futuro. Está sempre vinculada ao projeto, que é uma antecipação imaginária do comportamento que ainda está por acontecer que surge na vivência interpessoal, uma vez que a ação é interpessoal.

Mas cabe destacar que todas as nossas ações nos levam aos motivos para os quais estamos direcionados para o outro, visando a algo e aos motivos porque fomos levados a esse tipo de ação.

Para compreender o significado da ação de uma pessoa, a preocupação deve referir-se aos elementos relevantes que esta pessoa confere a sua ação, ou seja, a pessoa é responsável pela definição do significado da ação como situação do qual ela faz parte.

Dessa maneira, Fustinoni interpreta que a ação

\section{social}

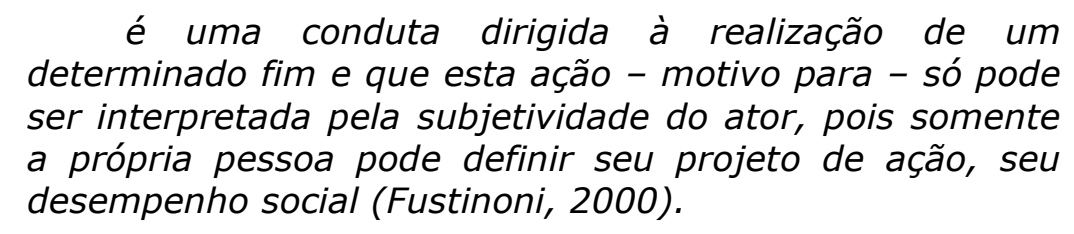

Soares (2004) destaca que a ação social nunca aparece isolada e tem sempre uma intencionalidade, podendo ser 
interpretada como um motivo para, que só encontra significado na subjetividade do ator.

Esse tipo de motivo refere-se ao futuro, a algo que se pretende realizar. Os motivos por que são oriundos das experiências já vivenciadas, representando as razões dos sujeitos em executar uma determinada ação; representa uma explicação posterior ao acontecimento, uma vista de olhos para o passado.

Nessa ótica, a ação social acontece na intersubjetividade do mundo comum, sustentada pela reciprocidade dos motivos; dá origem a uma tipicidade de ações estabelecidas socialmente - e aceitas pelos atores - oriundas de costumes, hábitos, regras, crenças em determinadas situações típicas (Schütz, 1974).

É preciso ressaltar que por meio da intersubjetividade se torna possível assimilar as experiências humanas, resultando na tipificação do senso comum.

Como esclarece Campoy (2003), a intersubjetividade para Schütz

" é uma categoria fundamental para a compreensão da existência humana no mundo; em geral, refere-se ao que é comum a vários indivíduos.

... as pessoas percebem-se como semelhantes, podendo um atuar sobre o outro, compreendendo e sendo 
compreendido na intersubjetividade do mundo da vida cotidiana.

É por meio de uma relação face-a-face que me torno consciente da existência do outro compartilhando uma simultaneidade real de cada uma das consciências distintas. Esta se estabelece a partir das interações sociais que ocorrem em um mesmo tempo e espaço.

Parte-se do princípio de que cada indivíduo tem suas experiências vivenciadas de forma individual, e é através da relação face a face que as experiências são trocadas. Nesse mundo social, a intersubjetividade permeia a troca dessas experiências possibilitando o surgimento das tipificações.

Conforme Schütz, as tipificações acontecem quando indivíduos agem de maneiras semelhantes, sedimentados nas experiências vivenciadas do mundo do senso comum. Quando existe uma reciprocidade de motivos, pressupõe-se uma tipicidade de ações.

Assim, emerge o tipo vivido, construído a partir das convergências das intenções dos sujeitos, que são os motivos para e os motivos porque como uma situação única construída pelos próprios atores sociais. 
Minha compreensão da fenomenologia de Alfred Schütz encontra-se esquematizada no ANEXO 1.

É nessa linha de pensamento de Schütz que o presente estudo busca construir o tipo vivido dos docentes enfermeiros e dos docentes de outras áreas da saúde em um Curso de Graduação em Enfermagem, procurando explicitar um cenário de absoluta particularidade. 


\section{CONTANDO A TRAJETÓRIA METODOLÓGICA}

\subsection{A região de inquérito}

É considerada região de inquérito da pesquisa o contexto social em que os sujeitos do estudo realizam suas ações; é o cenário onde o pesquisador procura conhecer o mundo-vida desses sujeitos, não apenas um espaço físico própriamente dito. É o local transparente das minhas preocupações; são as pessoas na sua experiência diária que eu estou interrogando; é o campo da minha curiosidade científica.

A região de inquérito é constituída de docentes de um Curso de Graduação em Enfermagem de uma universidade particular da cidade de São Paulo, onde é considerada uma tradicional Instituição de ensino superior. Trata-se de uma universidade que tem como missão a excelência do ensino e a formação de novos profissionais para a sociedade do conhecimento.

Possui 35 anos de existência. Nesse período tem procurado acompanhar as transformações da sociedade, criando novos cursos, em diferentes áreas do saber, adotando novas tecnologias de ensino, capacitando docentes e ampliando 
laboratórios e clínicas. Em sua trajetória, tem reorganiza seus procedimentos administrativos e estreitado seus laços com a comunidade, sempre com o intuito de tornar o aluno apto a entender o processo de transformação social e a ser um participante ativo de um mundo em mudança.

Atualmente possui 27 cursos de graduação e 34 cursos de pós-graduação, ampliando e diversificando as áreas de conhecimento distribuídos em 7 Campus e 34 prédios.

A missão do seu Curso de Enfermagem é a formação de profissionais competentes na prestação de assistência de saúde a indivíduos, a famílias e a grupos sociais, bem como no gerenciamento de equipes de enfermagem.

O curso tem como objetivo formar o profissional enfermeiro generalista numa linha humanística, com consciência crítica e reflexiva, qualificado para atuar nas áreas de assistência, administração, educação em saúde e investigação científica nos diferentes níveis de atenção à saúde. Em suma, a meta final é promover, prevenir, proteger e recuperar a saúde do ser humano. com vistas a promoção, prevenção, proteção e recuperação.

O currículo compreende disciplinas teóricas, e treinamento prático em laboratórios de anatomia, biologia, 
bioquímica, microbiologia e enfermagem. Dotados de equipamentos didáticos de última geração; contribuem para desenvolver o conhecimento e as habilidades específicas da profissão. No decorrer do curso, o estudante faz estágios das diversas áreas de especialização, em instituições de saúde.

Esse curso contempla dois modelos curriculares: um com carga horária total de 4.160 horas/aula e o mais recente com 3.960 horas/aula. Ambos são compostos tanto por conteúdos programáticos obrigatórios, representados por um conjunto de disciplinas quanto por conteúdos complementares de caráter optativo, constituídos por atividades complementares com carga horária obrigatória. Possui atualmente cerca de 1.500 alunos matriculados, número semelhante ao momento em que os dados do presente estudo foram coletados.

\subsection{Os sujeitos da pesquisa}

O foco de interesse para deste estudo é constituído pelo mundo social vivido dos docentes enfermeiros e docentes de outras áreas da saúde de um curso de graduação em Enfermagem da universidade acima referida. Essa escolha deveu-se ao fato de esses sujeitos terem vivenciado o objeto de minhas inquietações. 
No período da coleta de dados, o corpo docente dessa instituição era composto por 57 professores em atividades de ensino, pesquisa e extensão. Quanto à sua titulação, havia 13 professores doutores, 32 mestres, 10 especialistas e 2 graduados.

Para que pudessem fazer parte da pesquisa, utilizei os seguintes quesitos como critério de inclusão: os que vivenciavam a situação da docência em disciplinas teóricas ou teórico-práticas, básicas ou profissionalizantes; aqueles que trabalhavam nesse curso de enfermagem há, pelo menos, dois 2 anos; enfermeiros e demais profissionais, independentemente da disciplina que ministrassem, ou do semestre em que estivessem atuando.

Pela natureza da pesquisa, não foi delimitado com antecedência o número de participantes. Foram entrevistados 4 docentes enfermeiros e 4 docentes de outras áreas da saúde (1 dentista, 1 biólogo, 1 nutricionista e 1 médico-veterinário) em condições de atribuir significações às suas experiências vividas no Curso de Enfermagem.

Um outro critério utilizado com o objetivo de garantir o anonimato de cada participante foi identificar os docentes enfermeiros com nome de frutas: Jambo, Cupuaçu, Carambola e 
Castanha-do-Brasil; e os docentes de outras áreas da saúde pelos apelidos de Acerola, Pitanga, Açaí e Buriti.

O número de sujeitos foi delimitado em função de seus conteúdos terem sido suficientes para responder minhas inquietações por meio das questões norteadoras que foram formuladas para virem ao encontro do descortinamento do fenômeno.

Os docentes enfermeiros apresentavam a seguinte situação biográfica: tinham entre 40 e 44 anos, 2 cursaram a graduação em universidade pública; e 2 em universidade particular; 1 possuía licenciatura; 4 com título de especialização; 3 mestres e 1 doutor. Tinham entre 17 e 21 anos de formados; entre 5 e 14 anos no exercício da docência; entre 2 e 3 anos atuando na instituição; e 2 trabalhavam concomitante em outra instituição privada.

Os docentes de outras áreas da saúde apresentavam a seguinte situação biográfica: tinham entre 31 e 45 anos; 1 cursou a universidade pública e 3 a universidade particular na graduação; 1 possuía licenciatura; 2 com título de especialização; 3 mestres; e 1 fazendo mestrado. Tinham entre 10 e 20 anos de formados; entre 4 e 17 anos exercendo a docência; entre 4 e 6 
anos na instituição e 3 trabalhavam concomitante em outras instituições privadas.

Nenhum desses docentes cumpria jornada de 40 horas e seus contratos abrangiam diferentes cargas horárias.

\subsection{Preceitos éticos da pesquisa}

A resolução no. 196/96 do Conselho Nacional de Saúde estabelece determinados preceitos éticos quando se trata de pesquisas que envolvem seres humanos. Dessa maneira, algumas medidas foram tomadas para contemplar essas exigências.

A primeira iniciativa foi encaminhar no dia 01 de setembro de 2004 uma carta de solicitação de coleta de dados ao Sub-Comitê de Ética em Pesquisa (ANEXO 2), da instituição onde este estudo foi realizado. O parecer favorável foi concedido no dia 10 de setembro desse mesmo ano.

O documento de concessão não está anexado neste trabalho. Isso se explica pelo fato de a instituição ter solicitado a garantia de seu anonimato. Todavia, este documento encontra-se em meu poder, podendo ser analisado, caso haja necessidade.

Dirigi-me pessoalmente a cada um dos docentes para que a entrevista pudesse ser agendada de acordo com a 
disponibilidade de tempo e com a preferência do local para as entrevistas serem feitas.

As entrevistas foram realizadas nas salas de aula da própria universidade quando não estavam sendo utilizadas ou, então, em outros locais, a pedido do participante. O objetivo era manter a privacidade de cada um dos entrevistados.

Antes de iniciar o diálogo esclareci aos entrevistados os objetivos da pesquisa; assegurei-Ihes a garantia do anonimato e a liberdade de participar ou não do estudo, antes durante ou após a entrevista, a fim de que seu depoimento não lhe causasse prejuízo de qualquer natureza.

Para obter sua participação na pesquisa, elaborei um Termo de Consentimento livre e esclarecido (ANEXO 3), em linguagem acessível, o qual, após leitura e aceite dos participantes, foi assinado em duas vias (uma para o sujeito da pesquisa e outra para mim).

A partir de uma percepção subjetiva, fui identificando em cada um deles características semelhantes a determinadas frutas tipicamente brasileiras. Desse modo, achei interessante preservar o anonimato dos participantes - conforme o combinado atribuindo-Ihes apelidos. 
Passaram então a se chamar: Acerola, Jambo, Pitanga, Cupuaçu, Açaí, Carambola, Buriti e Castanha-do-Brasil.

\section{$5.4 \quad 0$ estudo preliminar}

A entrevista é uma das técnicas mais utilizadas no campo das ciências sociais. Ela permite a obtenção da descrição do vivido pelos sujeitos da pesquisa, utilizando-se questões norteadoras embasadas na imparcialidade do pesquisador, como ensina Peres (2001). Por essa razão ela foi utilizada neste estudo para obter o discurso de cada um dos participantes

Com efeito, a entrevista é bastante adequada para a obtenção de informações acerca do que as pessoas sabem, crêem, esperam, sentem e percebem as coisas e o mundo (Marconi e Lakatos, 1999).

Essa técnica consiste na apropriação, pelo entrevistador, de uma questão ou de um conjunto delas para salientar junto aos entrevistados seus principais pensamentos e opiniões, quando colocados em contato com um assunto ou uma situação específica. Em vista de sua utilidade prática, foi selecionada por facilitar a compreensão do objetivo deste trabalho. 
Antes da coleta das informações, senti a necessidade de conviver com a experiência da entrevista, visto que seria a primeira vez que estaria utilizando esse instrumento de pesquisa e precisaria, assim, adaptar-me às suas peculiaridades.

Sem dúvida, era de fundamental importância que eu devesse verificar a adequação da questão norteadora a qual deveria extrair dos discursos os motivos que estão voltados para a ação dos sujeitos, ou seja, os "motivos para" como retrata Schütz.

Dessa maneira, utilizei as questões norteadoras abaixo especificadas acreditando que estas pudessem desvelar o fenômeno a ser estudado. Assim foram elas formuladas:

- Como tem sido suas ações docentes neste curso de Enfermagem?

- O que você espera agindo desta forma?

Convidei uma docente enfermeira para que fizesse parte do meu estudo preliminar, Aceitou prontamente, e então marcamos então o dia e o horário da entrevista, tendo sido respeitada a sua preferência. Segui todos os preceitos éticos já explicitados anteriormente. 
A entrevista aconteceu num clima bastante agradável sendo feita a gravação em fita K-7 com duração de 15 minutos. A entrevistada declarou ter compreendido com clareza as questões a que foi submetida.

Após as gravações em fita $K-7$, o seu conteúdo foi transcrito na íntegra no papel em escrita cursiva e depois digitada, com o cuidado de não omitir qualquer informação gravada, mesmo em seus detalhes. Assim, acreditei não ser necessário modificar as questões norteadoras, pois respondiam às minhas inquietações, e dei início à coleta de dados.

\subsection{A obtenção dos discursos}

A coleta de dados aconteceu no período de 4 a 22 de outubro de 2004. Cabe ressaltar a rapidez com que a coleta foi feita devido à imensa disponibilidade que os docentes demonstraram ter para participar do estudo.

O convite para os docentes do Curso de Enfermagem participarem da pesquisa foi feito por meio eletrônico (e-mail), servindo-me de uma listagem dos endereços eletrônicos solicitada na secretaria da escola. 
Optei por essa forma de convite por ser uma via de comunicação rápida. Além do que, faz parte da rotina de transmissão de informações para os docentes do curso, os quais, por sinal, já estão familiarizados com a sua utilização. Fui selecionando os docentes pela ordem de chegada dos e-mails os quais respondiam que gostariam de participar do estudo.

Após a confecção dessa listagem, abordei cada um dos docentes pessoalmente para que pudéssemos agendar a entrevista de acordo com a disponibilidade e a preferência de cada um. Coincidentemente, as entrevistas foram acontecendo de forma intercalada com docentes enfermeiros e de outras áreas do conhecimento.

As entrevistas foram realizadas em salas de aula na própria universidade que não estavam sendo utilizadas, quanto em outros locais escolhidos pelos docentes.

Por também fazer desse corpo docente, eu tinha vivido uma relação face a face com essas pessoas. Conhecia, então, um pouco a situação biográfica e a bagagem de conhecimentos de cada um. Assim sendo, a existência dessa intersubjetividade me levou a acreditar que o entrevistado se sentisse à vontade para expressar suas vivências, respondendo 
com liberdade o que desejassem e não tendo limite de tempo préestabelecido.

Inicialmente informei a cada entrevistado o objetivo do estudo e segui todos os preceitos éticos da pesquisa. Ofereci o Termo de Consentimento livre e esclarecido e somente após o esclarecimento e a concordância em participar do estudo é que iniciei a entrevista.

Uma vez constatada a eficácia das questões norteadoras do estudo preliminar, elas foram igualmente utilizadas na obtenção dos discursos, ou seja:

- Como tem sido suas ações docentes neste Curso de Enfermagem?

- O que você espera agindo desta forma?

Os relatos foram colhidos através de gravação dos depoimentos em fita K-7. Posteriormente, segui o mesmo procedimento adotado na transcrição da entrevista do estudo preliminar (ANEXO 4). O propósito foi apreender o significado dos discursos dentro da vivência global de cada um dos entrevistados e identificar as unidades de significados.

É pertinente observar, todavia, que o papel manuscrito ou digitado - material inerte - não registra emoções e 
sentimentos, entonações de vozes e outras manifestações do discurso que reforçam a sensibilidade da comunicação humana, infelizmente.

Frente a essas colocações, utilizei os pressupostos da fenomenologia, tendo como base o referencial filósofo de Alfred Schütz, permitindo vislumbrar um horizonte mais amplo sobre o fenômeno a ser desvelado.

\subsection{Vivenciando a análise compreensiva}

O processo de transcrição de todo o conteúdo das gravações proporcionou-me um estágio de profunda imersão nas falas dos sujeitos, visto que era necessário ouvir diversas vezes a gravação para que eu pudesse transcrevê-la.

Uma vez transformando o discurso oral em discurso escrito, o próximo passo foi fazer a leitura individual de cada um deles com a intenção de me familiarizar com o conjunto e apreender o sentido global da vivência desses sujeitos.

Para construção das categorias, utilizei os estudos de Freitas (2005), Merighi (2000), Fustinoni (2000). 
Dessa forma, fui percorrendo as seguintes etapas:

- leitura seqüencial, detalhada e exaustiva de cada discurso, procurando identificar unidades de significado;

- leitura das unidades de significado, agrupando-as de acordo com suas convergências para formar as categorias concretas dos vividos desses sujeitos;

- após a construção das categorias, foram identificadas aquelas que expressavam os motivos para e os motivos porque das ações dos docentes do Curso de Enfermagem;

- iniciou-se a análise compreensiva das categorias, baseada no referencial filosófico-metodológico de Alfred Schütz;

- construção do tipo vivido dos docentes do Curso de Enfermagem. 


\section{CONSTRUINDO AS CATEGORIAS CONCRETAS DO VIVIDO}

A elaboração dessa etapa teve início após terminar a e a transcrição das informações obtidas as quais foram analisadas uma a uma, de maneira cuidadosa e detalhada. Em seguida à análise individual, fiz uma análise da totalidade dos discursos. O objetivo era apreender o significado do todo mediante agrupamento das falas que eram convergentes, ou que apresentavam semelhança quanto ao assunto ou ao tema.

Desse modo foi possível construir as categorias concretas do vivido oriundas das experiências vividas no mundo cotidiano. Isso em relação aos docentes enfermeiros e em relação aos docentes de outras áreas da saúde.

Com a intenção de buscar os motivos porque e os motivos para, utilizei nessa construção as duas questões norteadoras apresentadas acima.

Após lançar-me em profunda imersão nos discursos, foi possível perceber que eles apresentavam reciprocidade porque a docência lhes eram um denominador comum - quanto a ação docente e o que esperavam agindo dessa forma. O como 
vivenciavam suas ações e idealizavam seus projetos apresentou-se comum na visão dos dois sujeitos.

6.1. Categorias emergentes dos motivos para que emergiram dos discursos dos docentes enfermeiros e dos docentes de outras áreas da saúde.

Com relação a essas categorias, busquei, inicialmente, os motivos para, presentes nos discursos dos docentes os quais apontariam os seus projetos, ou seja, as ações futuras, as expectativas, os propósitos de cada um.

Emergiram, então, as seguintes categorias: o aluno como futuro profissional, o crescimento pessoal do aluno, o docente como pesquisador, os conteúdos. Elas são apresentadas em conjunto, considerando-se a reciprocidade dos dois sujeitos em seus discursos.

\section{O aluno como futuro profissional}

Nessa categoria, os discursos indicam a preocupação do docente em formar um profissional que, por meio da crítica, reflita sobre seus saberes, suas atitudes e comportamentos. Deseja poder auxiliar o aluno, futuro profissional, a perceber e buscar soluções para os problemas. Exemplifica sua fala com algumas situações de enfermagem onde o aluno estará atuando junto à 
população. Tem, igualmente clareza da sua contribuição na formação do profissional, mesmo não sendo enfermeiro. Acredita que o aluno deva ter um comportamento ativo em busca da própria aprendizagem para se tornar um bom profissional. Sua intenção é de que o aluno tenha capacidade de tomar decisões, que questione sua própria prática mas que também seja tecnicamente competente. Ainda espera ver um profissional que seja humanizado e com capacidade de trabalhar em equipe.

... no final de tudo, o produto é eu ter um enfermeiro com qualidade de enfermeiro, com formação compatível com a de um enfermeiro, com a capacidade de pensar como enfermeiro, capacidade de agir como enfermeiro.

Jambo

... para que eu consiga realmente chegar no que eu entendo que é o ideal: é você ter um enfermeiro capaz de pensar, alguém que seja crítico, que seja reflexivo, e criticar não é falar mal; criticar é você ser capaz de perceber e de dar soluções para os problemas.

Jambo

E aí então, ao perguntar para o aluno questões que ele estaria enfrentando numa consulta de enfermagem, numa Unidade

Básica de Saúde, eu tenho essa intenção de que ele, a partir dos conhecimentos da aula, que ele aplique então no momento que ele está frente à mãe, por exemplo, que ele pode oferecer para essa mãe informações da nutrição, gerais, não tão aprofundadas quanto nutricionistas.

Açaí

Eu espero contribuir para a formação do enfermeiro e eu tenho claro que eu contribuo um pouco. 
... que ele pode, sim, conseguir conhecimentos que vão torná-lo um profissional de bom nível.

Buriti

Então, meu objetivo é fazer deles enfermeiros como eu imagino que deve ser a formação de um bom profissional.

Castanha-do-Brasil

Formar um enfermeiro que como eu gostaria de ter trabalhando comigo. Assim, bons profissionais, profissionais tecnicamente bons, mas sempre tendo esse outro lado, o lado humano, o lado de cooperação, o lado de saber trabalhar em equipe, mas especialmente de serem bons tecnicamente.

Castanha-do-Brasil

\section{O crescimento pessoal do aluno}

Essa categoria expressa o docente que tem a intenção de contribuir na formação de um profissional qualificado, não só do ponto de vista de conhecimentos, mas também que este aluno se torne uma pessoa mais bem capacitada sob o aspecto intelectual e cultural, e se aprimore nas relações interpessoais. Valoriza a busca desses conhecimentos além do espaço universitário, ou seja, nos livros, na vida e, dessa forma, acredita que esses alunos vislumbrem maiores dimensões para o futuro da enfermagem. Tem como ponto de partida compreender as características dos alunos estimulando-os a crescer o mais rápido possível como profissionais e como pessoas. Especificam o desejo de ter um aluno-pessoa que "seja inteiro", bem formado, que fale bem, que saiba ler e que saiba se portar. Quer mostrar para esse 


\author{
aluno a importância de se ter uma boa postura profissional e ser \\ necessário exercer uma liderança democrática e participativa frente \\ a sua equipe.
}

Eu espero do fundo do meu coração que eu tenha contribuído nesses anos como docente de alguma forma; estar plantando uma semente intrigante para que esses alunos vão além, que eles vão além da sala de aula, que eles vão além dos livros, que eles consigam ir além do intra-muros da classe, da universidade; e que eles consigam perceber maiores dimensões pro futuro da enfermagem. Isso é realmente o que eu espero.

Cupuaçu

... a gente tenta perceber essas características e, partindo deste universo, estimular para que eles consigam crescer o mais rápido possível na informação e na formação deles como pessoa, no mundo deles e como profissionais.

Buriti

Mesmo que ele seja um especialista, mas que ele seja inteiro, assim bem formado, que fale bem, que saiba ler, que tenha postura; que eu brinco com eles com os "pobrema" eu tô fora; eu quero pessoas que falem bem, que saibam se portar; que eu sempre falo pra eles uma frase que eu dizia no hospital: quando

fala o fulano de tal fez alguma coisa errada está se referindo

àquela pessoa mas quando fala o enfermeiro fez aquela coisa errada, está se referindo a mim também porque eu também sou enfermeira.

Castanha-do-Brasil

Então, nesse sentido eu faço deles, tento fazer, pretensão a minha querer fazer, mostrar pra eles a importância de ser um

profissional que seja inteiro, assim uma pessoa culta, uma pessoa que leia, uma pessoa que fale bem, que se porte bem, que tenha postura, que saiba chefiar sem ser rude, que saiba liderar um grupo sem ser mandão, sem ser autoritário. 


\section{O docente como pesquisador}

A valorização da pesquisa científica é apontada pelo docente quando este espera facilitar para os alunos a compreensão de todo o processo da pesquisa e da organização de trabalhos científicos. Destaca a importância do Trabalho de Conclusão de Curso e da Iniciação Científica como pontos de partida para os níveis mais avançados da pesquisa, como por exemplo, o mestrado. Preocupa-se em despertar no aluno um olhar investigativo e que ele possa identificar as fases do trabalho científico em tudo que for pesquisar no decorrer da sua vida profissional.

eu espero facilitar todo esse processo da pesquisa e da montagem do trabalho e que ..., claro, isso tem algum significado para ele depois porque o Trabalho de Conclusão de

Curso é um pouco um mestrado engatinhando; você vai começar a se especializar cada vez mais e vai estudar um grão de areia no meio de uma praia.

Pitanga

... eu espero que ele, ao término da Iniciação Científica, conheça a estrutura de um trabalho científico; e toda vez que ele for pesquisar alguma coisa, quando ele for pesquisar, que ele saiba identificar aquelas fases do trabalho científico em tudo que ele for pesquisar. Essa é a intenção. 


\section{Os conteúdos}

Fica clara a intenção do docente de desenvolver os conteúdos programáticos propostos pela disciplina, e que, ao final do curso, haja domínio desse conteúdo por parte dos alunos. Esse conteúdo deve ser o mais amplo possível, a ponto de permitir fortalecer a base de conhecimentos dos futuros profissionais.

Então, essa é a minha intenção em tentar sempre fechar o programa.

Pitanga

O que a gente espera, primeiramente, é que ele tenha um domínio bastante grande da parte de anatomia que ele vai usar para a clínica e, além disso, trabalhar na base desse aluno,...

Acerola

Ele tem que saber pelo menos para onde ele vai correr, para que livro ele tem que consultar, do que se trata.

... a minha intenção é,... claro, a gente não vai conseguir passar tudo para o aluno, mas deixar com que ele conheça $o$ maior número, a maior quantidade de informações possível para ele não ter a situação, assim, de sair da disciplina, ou até de

terminar o curso e falar, "puxa vida!, eu nunca vi isso na minha vida".

Pitanga

\subsection{Categorias emergentes dos motivos porque que emergiram dos discursos dos docentes enfermeiros e dos docentes de outras áreas da saúde.}

Nessa categoria procurei observar os motivos

porque presentes nos discursos dos docentes. Suas opiniões 
revelaram a forma com que têm desempenhado suas ações no Curso de Enfermagem.

Surgiram, então, as seguintes categorias, também apresentadas em conjunto: o aluno como futuro profissional, o crescimento pessoal do aluno, o docente como pesquisador, os conteúdos, os sentimentos distintos, a visão do que é ser docente, o perfil do aluno e as estratégias de ensino.

\section{O aluno como futuro profissional}

Ver o aluno como um futuro profissional significa para o docente organizar de forma específica o conteúdo de sua matéria para cada curso que ministra, vislumbrando a sua utilidade na carreira dos alunos. Os conhecimentos transmitidos poderão ser utilizados durante sua carreira, seja como enfermeiros, ou seja, por optarem atuar no futuro como docentes do curso de enfermagem. Acreditam e valorizam a idéia de trabalho em equipe e a possibilidade de uma interaprendizagem entre os profissionais. Apontam a necessidade da prática de reflexão, junto a esses alunos, sobre suas vivências e seu papel no contexto da equipe multidisciplinar. Valorizam a idéia de ministrar um ensino que seja significativo na vida pessoal e profissional dos alunos. Fazer com que o aluno reflita sobre a nossa prática, sobre as reais necessidades brasileiras, as reais necessidades do nosso país, do 
nosso povo e que ele compreenda as dimensões reais e futuras como profissional e como cidadão. Tudo inserido no contexto brasileiro e no contexto de um profissional da área de saúde. Dão a entender sua preocupação em fazer um ensino que seja significativo para o futuro enfermeiro, tendo o cuidado de não colocar questões muito específicas para eles. Procuram participar na construção de enfermeiros com um nível de formação diferente daqueles enfermeiros com os quais conviviam quando trabalhavam na área hospitalar.

A disciplina que a gente ministra é focada para as necessidades básicas do enfermeiro.

Acerola

Eu, como professor de disciplina básica, o que eu acho fundamental é que você saiba elaborar uma disciplina voltada para cada curso que você dá.

Acerola

Então, aqui, por exemplo, a gente tem uma metodologia de um curso voltado para a área de enfermagem.

Acerola

Se pegar uma outra área, como odontologia, é completamente diferente, um perfil diferente. Eu acho que as disciplinas básicas têm que ter muito esse cuidado.

Acerola

... mas eu acho isso fundamental para toda disciplina básica: é focar o curso na necessidade futura de cada curso. 
Então a gente tem sempre em mente esse enfoque: trabalhar as informações da anatomia que vão ser usadas pelo enfermeiro

lá na frente, durante a carreira e durante a época dele como docente do curso de enfermagem.

Acerola

... porque a gente acredita que, nesse campo, ele vai trabalhar sempre dentro de uma equipe, e a troca de informações vai ser muito importante.

Acerola

Então é um trabalho assim, de reflexão junto com esse aluno, trazendo à tona essas dificuldades que ele vive, inclusive tentando colocar isso junto com os conteúdos que a gente aborda na sala de aula ...

Jambo

Tenho também uma ação que eu acredito que seja muito motivadora. Eu motivo eles a estarem pensando nas perspectivas da enfermagem, estarem pensando no seu papel em relação a ... à importância do seu papel dentro da equipe de saúde e uma ação reflexiva também, né ?

Jambo

Do quanto nós somos participativos, o quanto nós deixamos de ser participativos, faz com que eles repensem um pouco, até por serem, profissionais da área de saúde; que eles tenham essa ação reflexiva em relação a essa prática, até onde que nós podemos chegar, até onde que nós estamos indo de verdade,

Jambo

Bom, na verdade, eu tenho, não sei se é a pretensão ou a esperança de contribuir na formação desse aluno, não só do ponto de vista técnico de informações e formação.

Cupuaçu

... mas também de tentar contribuir nas minhas aulas, durante as minhas aulas, que são aulas que refletem diretamente alguns problemas de morbimortalidade brasileira, muito fortes 
... eu tento sempre trazer nessas minhas aulas além desse aspecto formativo e informativo, que o aluno reflita, reflita sobre a nossa prática; que ele reflita sobre as reais necessidades brasileiras, as reais necessidades do nosso país, do nosso povo e que ele compreenda as dimensões reais e futuras como profissional e como cidadão, inserido dentro do contexto brasileiro e do contexto de um profissional da área de saúde.

Cupuaçu

... tive sempre a preocupação em fazer com que esse ensino para o enfermeiro fosse significativo pra ele; e eu sempre tive o cuidado de não colocar questões de ciência da nutrição muito específicas pra ele, porque eu não estava formando, eu não estou formando, auxiliando na formação de nutricionistas; eu sempre tenho que ter isso em mente na minha ação educativa, na minha ação como docente, então ...

... e é um ponto básico que para mim, como eu ministro uma disciplina, eu sou outro profissional ministrando uma disciplina então para um futuro enfermeiro aí, contribuindo para a formação do enfermeiro.

Açaí

... e eu tenho sempre que ter em mente como aquele enfermeiro vai utilizar os conhecimentos da ciência da nutrição, para eu poder direcionar minha ação como docente, então, no desenvolvimento da disciplina.

Açaí

Eu tento colocar as questões principais de atuação deles, por exemplo, a nutrição do ambiente hospitalar;, onde é que vai então o papel de enfermeiro no cuidado nutricional do paciente hospitalizado, e aí eu trago questões pra eles sobre como é a nutrição frente à patologia.

Açaí

... eu trabalho com um artigo falando realmente do cuidado nutricional, do papel do enfermeiro no cuidado nutricional dos pacientes. 
Então, quando eu comecei dar aula não nessa escola mas numa outra escola, eu tinha na minha cabeça assim que eu não queria ver os profissionais que eu participava ou participo da formação

com nível de formação dos enfermeiros que eu via no hospital onde eu trabalhava.

Castanha-do-Brasil

\section{O crescimento pessoal do aluno}

Para o docente, a função de colaborar na formação do aluno como indivíduo faz parte do seu papel; ainda mais pelo fato de esses alunos se constituírem um grupo com características diferentes de outras universidades. Procuram explicitar a importância de valores como respeito e solidariedade contextualizando o ensino no universo dos alunos. Buscam fazer a docência de forma holística, na tentativa de ajudar esses alunos a enfrentarem a vida de forma plena e equilibrada.

Porque eu entendo que eu tenho essa responsabilidade muito grande com esse indivíduo, na formação desse indivíduo, até porque nossa clientela ela tem uma característica diferente de outras universidades.

Jambo

Eu acho que um momento de um aprendizado geral, na verdade, é um crescimento muito grande que os alunos apresentam nessa fase de vida, de estudo; é um salto muito grande para eles.

Buriti

A gente procura muito trabalhar com isso demonstrando para eles que a área de saúde é uma área fundamental para você ter respeito, onde você tem que ter solidariedade; então a gente 
procura trabalhar muito esses conceitos, dentro e fora da disciplina extrapolando coisas da disciplina um pouquinho.

Acerola

Quanto mais informação e formação eu puder estimular é o que eu faço. Mas sempre procurando os objetivos da aula, os objetivos específicos da aula e, até por que não?, orientá-los em situações pra vida. Buriti

Eu acho importante você entender o aluno no universo que ele está, não é ? Aqui na universidade eles tem características que são próprias deles e a gente tenta perceber essas características e partindo deste universo estimular ... Buriti

E eu acho que a formação na universidade tem que ser global.

Buriti

Eu valorizo mais o indivíduo que cresça não só profissionalmente mas como pessoa também, como indivíduo, para ter um desenvolvimento mais pleno, mais completo, mais equilibrado ...

Buriti

\section{O docente como pesquisador}

Nessa categoria, os docentes declaram que a orientação de trabalhos de pesquisa científica, como Trabalho de Conclusão de Curso e Iniciação Científica também faz parte de suas competências. Porém assinalam algumas dificuldades que encontram no desenvolvimento desses projetos como, por exemplo, o fato de o aluno ser trabalhador. Buscam despertar o 


\section{olhar investigativo do aluno trabalhando em parceria, como colaboradores e parceiros de todo esse processo.}

... e nas Iniciações Científicas visando mostrar para o aluno as formas de pesquisa existentes, como é que eles vão trabalhar para tentar orientá-los no sentido de trabalhos científicos mesmo, pesquisa. Acerola

... instigando a pesquisa científica, instigando a curiosidade científica, o conhecimento e o relacionamento.

Acerola

Aí tem orientações do TCC, que é uma coisa assim: na minha opinião eu gosto de trabalhar a orientação. Então, assim, eu me sinto bem trabalhando na orientação.

Jambo

$$
\begin{array}{r}
\text {... assim, ... trabalho de pesquisa ... enquanto docente, eu } \\
\text { tenho essa obrigação. }
\end{array}
$$

Jambo

Esse semestre eu concluí um trabalho de pesquisa que a gente estava fazendo em relação a uma atividade, que era um compromisso que eu tinha aqui da escola.

Jambo

A Iniciação Científica tanto quanto o TCC acho que é importante para o aluno porque ele escolhe o que ele quer estudar mais.

Então essa é a grande vantagem, a grande motivação desse aprendizado. Ele escolheu desde o 30 ano; ele já fez o projeto naquele tema, então é aquele que ele quer estudar. Então isso já motiva um pouco, mas eles têm dificuldade no andamento do trabalho por questões, lógico, de ser aluno trabalhador também; então, por questões da gente conseguir conciliar horário do professor com o horário do aluno. 
Então fazer um TCC, mesmo que não seja da vontade deles ser um pesquisador, que como é exigência do currículo, que mesmo

não sendo exclusivamente pesquisador, como enfermeiro, ele vai ter que ter essa curiosidade investigativa, uma coisa de participação da formação deles, mesmo que eles não vejam importância como pesquisador, mas sempre muito como parceira, como amiga deles.

Castanha-do-Brasil

\section{Os conteúdos}

As falas desses discursos indicam uma ação docente voltada para a relação prática-teoria-prática fortalecendo, assim, seus saberes. Utilizam a curiosidade do aluno como aliada de suas ações, buscando associar o que eles vêem na prática com uma grande quantidade de conteúdos vistos na universidade. Acreditam que, mesmo assim, pelas características dos alunos e da estrutura universitária na qual estão inseridos, ainda enfrentarão situações na vida profissional que não foram abordadas durante o curso. Mostram uma visão atual do panorama do país, a realidade de morbi e mortalidade do Brasil, as perspectivas que se apresentam dentro da área de enfermagem, e exemplificam com situações nas quais irão se deparar no seu cotidiano como enfermeiros. Trabalham com conteúdos sobre escrita, análise de artigo científico, elaboração de texto acadêmico, apontando suas partes essenciais. Mostram a preocupação em fazer um ensino que seja significativo para o enfermeiro abordando assuntos que sejam coerentes com a vida real, concretos e úteis, ricos de exemplos e 


\section{voltados não só para os aspectos técnicos, mas também para os aspectos humanos e filosóficos do cuidado.}

... eu tive sempre a preocupação em fazer com que esse ensino para o enfermeiro ele fosse significativo pra ele; e eu sempre tive o cuidado de não colocar questões de ciência da nutrição muito específicas pra ele, porque eu não estava formando, eu não estou formando, auxiliando na formação de nutricionistas; eu sempre tenho que ter isso em mente na minha ação educativa, na minha ação como docente, ...

Açaí

e em cima disso, também a gente trabalha toda a parte teórica, dando embasamento para eles, além daquelas partes que ele vai ter necessidade como conhecimento geral sobre o corpo humano, todas as informações anatômicas do funcionamento do corpo humano.

Acerola

Então a gente já procura, desde o primeiro ano a ter, a orientar isso, a trocar conhecimento, conhecimento clínico, e isso a gente abre também nas aulas teóricas.

Acerola

Então a gente procura jogar sempre com essa curiosidade deles e a relação com o que eles vêem na prática e o trabalho da faculdade, que é um trabalho muito mais acadêmico.

Acerola

por algumas razões: uma delas é característica das próprias disciplinas que eu ministro; são disciplinas complexas; os alunos são primeiranistas, muitas vezes do primeiro semestre; é uma quantidade de assuntos grande, muita informação e ...

Pitanga

... eu embora tenha toda essa questão de não ser conteudista, eu ainda acho que a gente tem também que ter o pé no chão e saber que, se esse aluno ficar faltando muita coisa para ele, ele

vai sair daqui muitas vezes sem saber o que ele vai encontrar por aí e... então, pela característica da disciplina, pela estrutura 
da sala de aula e pelo número de alunos.

Pitanga

E tento também abrir perspectivas para esses alunos no sentido de mostrar uma visão atual do panorama do país, das perspectivas que se apresentam dentro da área de enfermagem.

Cupuaçu

Então, eu procuro também, por exemplo, quando eu abordo a questão de uma criança com aleitamento materno e depois os outros tipos de leite, fórmulas infantis.

Açaí

Então eu coloco um caso de uma mãe que chega na Unidade Básica de Saúde e coloca pro enfermeiro: "olha, eu to dando água pra minha criança além do leite materno porque eu acho que ela tem sede" Aí, o que você faz com essa frase da mãe? Eu pergunto, eu questiono o aluno, porque eu antes passei todo conteúdo do aspecto nutricional do leite materno.

Açaí

Então, quando eu abordo esse conteúdo com eles e, posteriormente, eu trago esse caso também, em forma de caso, lógico que eu coloco também a questão do crescimento da criança.

Açaí

Análise de crescimento, mas mais puxando pra nutrição. Então, relacionar a nutrição dessa criança com o crescimento dela. Tá afetando o crescimento ? Tá adequado esse crescimento ? $O$ que pode ser de erro alimentar que está afetando esse crescimento etc. $O$ vínculo, então, da nutrição com o crescimento.

Açaí

No momento em que eu ministro uma disciplina, eu procuro estar inserindo nessa disciplina informações pertinentes à mesma e voltados para a realidade de morbimortalidade do Brasil. Então eu tenho uma ação, em primeiro lugar, 
Então, por exemplo, nessa disciplina de Métodos, no decorrer da disciplina a gente trata vários conteúdos sobre escrita, sobre trabalho acadêmico, sobre análise de artigo científico, elaboração de texto acadêmico; o que tem uma introdução, o que vale uma introdução no desenvolvimento e conclusão de um trabalho.

Açaí

... eu tive sempre a preocupação em fazer com que esse ensino para o enfermeiro ele fosse significativo pra ele; e eu sempre tive o cuidado de não colocar questões de ciência da nutrição muito específicas pra ele, porque eu não estava formando, eu não estou formando, auxiliando na formação de nutricionistas, eu sempre tenho que ter isso em mente na minha ação educativa, na minha ação como docente, então ...

Açaí

Na minha disciplina eu falo muito de humanidade; eu trabalho muito com o aspecto humano da gravidez, parto, da condição de ser mulher, mais filosófica talvez, e que não chega ao aluno.

Carambola

Então eu preparo as aulas ante; , eu tenho um conteúdo para cumprir.

Buriti

Nas aulas dessas matérias básicas que a gente sabe até que não são matérias que eles gostam, porque eles acham que ser

enfermeiro não precisa ver outra coisa a não ser doença; eu tento sempre trazer exemplos da Enfermagem; mesmo na História da Enfermagem eu tento puxar pra nossa vivência atual, do que ... que fatos históricos tem hoje na Enfermagem,

Castanha-do-Brasil

\section{Sentimentos distintos}

Ao relatar suas ações, os sujeitos demonstraram vivenciar sentimentos distintos que transitavam entre satisfação, 
prazer e gratificação no relacionamento que estabeleciam com os alunos. Mesmo aqueles que não possuíam muita experiência como orientadores de trabalhos científicos, vêem tal atividade como um desafio a ser enfrentado. Declararam que o contato mais individualizado com o aluno facilita a condução do trabalho docente e o desenvolvimento dos projetos, pois podem identificar as dificuldades apresentadas por esses alunos. Sentem-se bem quando atuam na parte prática da disciplina. Apontam a necessidade de uma busca de conhecimento permanente para que possam acompanhar o ritmo desenfreado da era do conhecimento. Trabalham como docentes por gostarem do que fazem e sentem uma profunda satisfação em poder colaborar, de forma conjunta com os outros docentes, na formação do aluno.

O contato com o aluno para mim é muito prazeroso; isso me faz bem, isso me deixa contente.

Jambo

Hoje, por exemplo,... foi muito gostoso, foi uma atividade gostosa com o aluno; alunos que eu não conhecia, a gente conseguiu fazer um trabalho legal; ...isso é prazeroso ...

Olha, a prática de orientação é um pouco recente para mim; eu estou no $3^{\circ}$. ano de orientação. Cada ano vem se tornando mais fácil; é o que se espera. É ... mas tem sido muito gratificante. Esse ano, particularmente, porque se modificou o critério de seleção com a entrevista, tá muito melhor, porque o aluno corresponde mais ao que você esperava. 
Agora em relação à IC e TCC, você tem a possibilidade de trabalhar ali individualmente com o aluno. Então esclarecer dúvidas de como elaborar um trabalho; então eu tenho visto que a prática na IC, minha ação docente na IC, e no TCC, ela tem sido muito é... prazerosa, assim nesse sentido de... você poder verificar qual realmente é a deficiência daquele aluno.

Açaí

Agora, em outros momentos como orientação de trabalhos..., quando são contatos mais individuais, eu tenho mais facilidade.

Carambola

Então esse é um momento em que eu estou bem, que eu não estou em conflito, nessa parte mais prática.

Carambola

Mas a resposta vem de forma simples. É uma aptidão que eu acho que eu tenho e facilidade para passar o que eu sei, acho que tenho muito a aprender. Quanto mais eu estudo, mais eu acho que eu tenho a aprender e acompanhar as evoluções e tal. Acho que é prazeroso.

Buriti

Mas, no geral, eu faço porque gosto; então não é por dinheiro; não é por poder; é, na verdade, por uma satisfação, um gosto, uma aptidão.

Buriti

Então eu tenho uma satisfação muito grande quando a gente percebe que uma pessoa partiu de um ponto por si só; não estou dizendo que eu sou responsável exclusivo por isso, não; mas ela parte de um ponto e com a sua ajuda, com um pouquinho de estímulo, nesse ensino e aprendizado ela chega a um outro ponto que normalmente é melhor; é além do que ela tinha; e esse ganho é muito satisfatório prá mim. Buriti

Nos discursos dos docentes, os sentimentos negativos estiveram muito mais presentes do que os sentimentos positivos. Foram identificados como insatisfação, angústia, 
desprazer, frustração, sobrecarga de trabalho, ansiedade, decepção, conflito e inadaptação ao meio. Relacionaram esses sentimentos com o excesso de trabalho e ao seu ritmo acelerado, ou ainda ao fato de não haver linhas de pesquisa, ficando, então, a critério dos alunos escolherem os temas de seus trabalhos científicos. Revelaram ter pouco tempo para ficar com a própria família, tendo que priorizar o trabalho para poder manter-se e deixar seu autocuidado renegado para quando sobrar um tempo disponível. Citaram uma incongruência entre o ensino que vem sendo ministrado e o tipo de aluno com o qual se deparam na sala de aula. Colocaram a existência de um distanciamento entre eles e os alunos pelo fato de eles não conseguirem alcançar o que tem sido ensinado, vendo-se inadaptados ao meio em que atuam. Ainda mostraram que o excesso de aulas e, conseqüentemente, a repetição dos conteúdos não os agrada.

... e assim, insatisfação com o trabalho porque o trabalho tem que te dar prazer; até porque eu faço o que gosto; e se eu faço o que gosto ele tem que me dar prazer e muitas vezes eu não sinto isso prazeroso. Então assim, não sinto prazeroso por conta dessas pendências, desse ritmo.

Jambo

É ..., não gosto muito do ritmo em que se trabalha a orientação aqui, porque você não tem opção de escolher o tema; você trabalha qualquer tema; o tema é imposto. Então, como você não tem opção, você é obrigado a orientar aquilo que vem para 
O pouco tempo que sobra você tem família ainda (risos ...), você também tem família e precisa também estar um pouco ainda com a família. Por isso você não pára pra pensar em você. Você pára pra pensar em você, aí você vai ver que não dá tempo de pensar em você, na família e no seu trabalho. Então você prioriza o trabalho, porque é dele que você depende e a família, porque, afinal de contas, não dá para você abandonar. E em você, quando der, você lembra e faz alguma coisa por você, pessoalmente.

Jambo

Então, o que pode ter hoje, depois dessas transformações, eu vejo sim, ainda em conflito, achando que a formação que a gente dá é como se fosse para o nosso aluno ideal e não para o aluno real que a gente têm na sala de aula.

Carambola

Eu me sinto extremamente distante desses alunos em muitos aspectos, eu vejo que muitas coisas que eu falo eles não alcançam, não chega até eles, ...

Carambola

Então, nesse ponto eu me sinto assim muito frustrada, muito mesmo; então, assim essa coisa de trazer o tempo inteiro o aluno para uma coisa tão palpável, tão básica, em alguns momentos eu falo: "gente, mas que enfermeiro vai ser este?"

Frustra bastante!

Carambola

Então eu me vejo às vezes muito inadaptada ao meio em que estou!

Carambola

... o excesso de aulas às vezes, então, torna a gente um pouquinho menos interessante; nas aulas temos que repetir várias vezes; entra naquela repetição e você, como professora que é, sabe que a gente às vezes repete a mesma aula para turmas diferentes e não me agrada muito isso.

Buriti 


\section{A visão do que é ser docente}

Ao refletirem sobre o que é ser docente, os discursos apontaram para uma valorização e um respeito à diversidade de alunos que encontramos nas salas de aula. Mostraram também uma percepção de que é possível trabalhar as dificuldades apresentadas pelos alunos a partir de suas vivências. Apesar das dificuldades surgidas durante o processo de ensino-aprendizagem, visualizam possibilidades de atuação. Mesmo não estando, em alguns momentos, inspirados para orientarem, tentam fazê-la da melhor forma possível. Refletem sobre a desvalorização do professor quanto à sua remuneração, e destacam que não basta ter um profissional altamente preparado tecnicamente se é uma pessoa com dificuldades de se relacionar. Mostraram preocupação em fazer um ensino que consiga relacionar a teoria com a prática através da experiência profissional do professor.

... porque eu entendo a docência de uma forma assim: você caminha de acordo com os passos da turma, tentando fazer com que essa turma caminhe, ...

Jambo

Então, assim, é justamente com essa visão de educador, de que esse indivíduo que vem para mim, ele vem com uma prática e um conhecimento que eu tenho que aproveitar essa prática e esse conhecimento; fazer com que ele perceba o que ele conhece, quais são as deficiências que ele tem nessa formação de base para eu poder trabalhar, então, em cima dessas 
deficiências ...

Jambo

... mas eu acho que nossa ação educativa é: frente às dificuldades, o que se tem de possibilidades? Porque tem possibilidades de atuação.

Açaí

Então, é variável, não são todos os dias que nós estamos também cem por cento favoráveis a orientar, mas, na medida do possível, a gente dá o melhor e exige que eles produzam da melhor forma. Buriti

Essa pergunta é quase romântica, porque, como professor, a gente não é altamente bem pago; não passo necessidades básicas, mas a gente não fica rico dando aula e, às vezes, eu também me pergunto: "o que que eu quero dando aula, onde eu quero chegar?".

Buriti

Não adianta a gente ter um profissional altamente preparado tecnicamente e intratável como pessoa, ...

Buriti

Então, durante as aulas, eu tento sempre trazer a minha vivência profissional daquele assunto como um exemplo pra ele; não digo como um espelho, mas assim, pra ele ter noção do como é ser enfermeiro.

Castanha-do-Brasil

Então, o tempo todo eu mostro pra eles o que eu fui, ou o que eu sou, se é que eu ainda sou, como enfermeira, para que eles até tenham um parâmetro de bom profissional ou ruim profissional, de acordo com os critérios do que eles estão vivenciando, que alguns são da área de saúde; outros não, mas sempre pensando assim, de ser um exemplo de pessoa, de professor, de me desculpar em cima de erros; mas sempre tentando ser um exemplo, acho, de profissional. 


\section{$O$ perfil do aluno}

Esses discursos caracterizaram o perfil dos alunos envolvidos no processo de ensino-aprendizagem identificando, na grande maioria, experiências na área de enfermagem, mesmo antes de sua inserção na universidade. Exerciam as funções de auxiliares e técnicos de enfermagem, com uma bagagem de conhecimentos extremamente heterogênea, dando a entender, assim, dificuldades, como por exemplo, dificuldade na leitura, problemas financeiros, por serem trabalhadores com excessiva carga horária de trabalho. Entretanto também citaram facilidades relacionadas com essas experiências. Porém, nos dizem que, mesmo com diversas dificuldades apresentam também inúmeras possibilidades que podem ser exploradas pelos professores.

Esse aluno que já vem com uma formação prévia, uma prática anterior em enfermagem como auxiliar ou como técnico, e eu não posso ignorar que ele tem um conhecimento que, se eu ignoro que ele já trás um conhecimento, eu deixo de ser educador.

Jambo

Eu vejo que isso é muito mais difícil quando você já tem um profissional que já tem uma prática prévia, do que quando você tem um aluno que não tem experiência nenhuma na área de enfermagem ... 
aluno com muitas carências, com muitas dificuldades, com muitas ..., já com um passado dentro da área de saúde muito heterogêneo,

É um aluno que traz dificuldades, mas ele também traz possibilidades. Então eu acho assim que a ação docente nossa fica entre verificar essas dificuldades, não esquecer essas dificuldades, mas verificar possibilidades frente a essas dificuldades.

Açaí

Por exemplo: dificuldade na leitura e escrita, é uma característica do aluno nosso, do perfil de aluno daqui; mas com essa dificuldade na leitura e escrita, o quê que a gente consegue que esse aluno leia um pouco mais?

Açaí

Então, assim, são questões que tem muita evasão ainda, do $1^{\circ}$ para o $2^{\circ}$ ano; tem uma diminuição de alunos por turma por questões financeiras; então tem uma série de dificuldades.

Açaí

Eu vim de um corpo docente de uma outra escola onde o nível, o aluno já ingressava nessa escola muito...com um padrão de ensino melhor e aqui eu tive que transformar a minha maneira de ver o aluno e de fazer a prática docente, eu tive que transformar essa prática até para chegar ao nível de entendimento desses alunos. Isso para mim não foi fácil, eu acho que eu tive uma série de dificuldades para entender essa diferença de tipo de aluno.

Carambola

Existe uma heterogeneidade muito grande no universo de alunos, então existem grupos que produzem mais do que

outros.

Buriti

A maioria tem jornada dupla, tripla, estudam, trabalham, trabalham num $2^{\circ}$. emprego, que acho que dificulta um pouco $o$ desempenho. Mas no limite deles, produzem, a gente procura estimular o máximo.

Buriti 


\section{As estratégias de ensino}

Sobre esse aspecto, os docentes demonstraram grande preocupação e interesse em diversificar as estratégias de ensino. Informaram que levam os alunos a constantes questionamentos sobre os conteúdos, despertando sua curiosidade científica e exercitando habilidades diferenciadas. Para isso, fazem uso do estudo dirigido, promovem discussões e seminários e desenvolvem aula expositiva dialogada de acordo com o conteúdo a ser estudado, com a disponibilidade de tempo, e com outras condições organizacionais disponíveis. Diversificam os recursos audiovisuais e procuram, em algumas situações, ensinar de forma descontraída.

Na parte prática, a gente orienta os alunos ou através de mesas
demonstrativas, ou através de estudo livre na prática, mas
sempre com um roteiro de estruturas anatômicas que ele tem
que conhecer, que são as mais necessárias para ele.

Acerola

Então, durante as aulas teóricas, a gente sempre instiga à perguntas, assim: "Alguém já viu isso na clínica? O que vocês tem de conhecimento disso na prática ? no dia-a-dia, vocês como técnicos ou auxiliares de enfermagem!"

Acerola

Então a gente procura jogar sempre com essa curiosidade deles e a relação com o que eles vêem na prática e o trabalho da faculdade, que é um trabalho muito mais acadêmico. 
A minha ação dentro da sala de aula é ... eu digo que ela é tradicional no sentido de utilização de estratégias; a maior parte do tempo eu trabalho com aula expositiva dialogada, é ...

Pitanga

Então tudo isso acaba contribuindo para que a aula seja uma aula expositiva. A maior parte das vezes eu utilizo como recursos a lousa, o giz e o retroprojetor; às vezes, data-show, principalmente na Histologia porque eu posso trazer fotos.

Pitanga

Às vezes eles fazem o estudo dirigido do assunto que vai ser tratado antes da aula. Então isso possibilita que o aluno durante a aula participe mais. Isso ajuda para mim, e acho que ajuda o

aluno.

Pitanga

Ah ..., não trabalho em CHE(Citologia, Histologia e Embriologia) com seminários; particularmente eu acho que é difícil você conduzir um seminário e... Eu trabalho em genética, algumas vezes com discussões porque são assuntos que eles têm, ao longo da disciplina; eles têm mais condições de ler e de discutir, mas eu não trabalho com seminários. Eles expõem, mas eles só vão saber quem vai expor no dia. Então todos eles tem que saber o assunto, e isso acaba levando a uma grande discussão mesmo. É ..., costuma ser bem interessante.

Pitanga

... e aí eu procuro, com estratégia, então de ensino, os estudos de caso, que eu acho que, como é uma disciplina teórica, como a minha, ela não envolve a prática; eu acho que dá pra contemplar de alguma maneira através da simulação, como estudo de caso.

Açaí

E a partir daí, desse objetivo, é que eu direciono então as minhas ações. Agora, em relação, por exemplo, em relação às estratégias que eu utilizo, eu utilizo sobre textos, procuro relacionar mais artigos científicos que trazem mais a questão mais atual do conhecimento. 
Esse é um ponto básico que, para mim, como eu ministro uma disciplina, eu sou outro profissional ministrando uma disciplina, então, para um futuro enfermeiro, aí, contribuindo para a formação do enfermeiro.

Açaí

O aprendizado é complexo aí e, da maneira como a gente expõe nas aulas, cada um aprende de uma forma, da sua forma, da sua maneira. Isso que é interessante também. Essa diversidade que ocorre no aprendizado.

Açaí

Preparo as aulas expositivas, com discussão; procuro pontos polêmicos, estimular raciocínio, informação geral; eu não gosto de nada muito encabrestado.

Buriti

Nas disciplinas técnicas Adulto, Idoso, UTI e PS é ..., dou aula de uma maneira um pouco mais lúdica; eu sou muito brincalhona; , brinco muito com as situações mas sempre tentando trazer a vivência hospitalar que eu tive, que é a maior experiência que eu tive.

Castanha-do-Brasil

\subsubsection{Outras categorias que apresentaram só motivos porque, surgindo em menor freqüência}

Foram encontradas outras categorias que apresentaram apenas os motivos porque os docentes tem suas ações no curso de enfermagem.

Estas apareceram em uma dimensão bem inferior as que já foram apresentadas anteriormente. São as seguintes: relação interpessoal professor-aluno, a estrutura universitária dificultando a ação docente, o trabalho 


\section{multidisciplinar, a própria formação docente, o trabalho em equipe e avaliação.}

\section{Relação interpessoal professor-aluno}

Nesse quesito, o docente se apresenta disponível para o aluno quanto ao esclarecimento de dúvidas de sua ou de outras disciplinas. Relata que tem aprendido com os alunos com a intenção de fazer uma docência mais qualificada. Os discursos revelam o desejo do aluno de se relacionar com o decente fora de sala de aula abordando diferentes assuntos, muitos distantes do processo ensino-aprendizagem, mas de cunho pessoal em que o docente, muitas vezes, o docente não se sente capacitado para ajudá-lo; faz então, um encaminhamento ou dá algumas sugestões. Demonstram vivenciar uma situação de parceria e de amizade em muitas situações.

Fora de sala de aula, eu procuro atender os alunos, sempre que eu sou solicitada; é ..., muitas vezes são dúvidas até de, assim, outras disciplinas ou de professores a mesma disciplina, e isso acaba trazendo uma situação um pouco constrangedora; mas eu também não costumo negar o auxílio.

Pitanga

... quanto ao aprendizado do aluno em relação à ação docente toda, eu tenho aprendido, também pra gente, porque aprender a gente não só ensina é uma relação de ensino-aprendizagem que a gente chama hoje aí, então, nessa relação ensinoaprendizagem. 
E aí eu aprendi também na semana passada com um aluno, comentando sobre o conteúdo da disciplina,

Então, a todo momento, o aluno também te traz um feedback; te traz também questões que você pode usar para você melhorar, aprimorar sua docência, e o aluno faz muito isso.

Açaí

Além das aulas, existe um contato que eu percebo aqui que é fora da aula, que é uma atenção para o aluno, que eles exigem, que eles clamam e que eu atendo na medida do possível, sim. Então, é uma conversa extra-oficial, de um problema particular, de um problema na família, de um problema que não precisa ser exatamente até de saúde e que, às vezes, algumas vezes, me sentindo incapaz de resolver, eu sirvo só como ouvinte, e às vezes encaminhar para um setor adequado de atendimento.

"Olha, eu acho que você pode procurar um psicólogo, pode procurar alguém específico para resolver o problema dele". Já aconteceram várias vezes aqui no curso esse tipo de solicitação, para atenção mesmo.

Buriti

Tento, fazer de uma maneira mais próxima do aluno; então as atividades tanto extra-classe quanto na classe.

Castanha-do-Brasil

Eu acho que a relação docente não só durante a sala de aula, durante a aula com atividades formais, como em corredores, em conversa com os alunos, de uma maneira sempre muito próxima deles.

Castanha-do-Brasil

Nas atividades extra-classe tipo Iniciação Científica, orientação de TCC, eu tento ser muito amiga deles, muito parceira, ouvindo muito o que eles falam, tentando mostrar pra eles que o fato de se tornar enfermeiro, que isso faz parte da formação de enfermeiro.

Castanha-do-Brasil

tentando sempre mostrar que ..., muitos, como são profissionais de Enfermagem já, eles tem a visão do enfermeiro 
aquele ser mandão, aquele ser autoritário; eu tento tirar um pouco isso deles.

Que dá pra você ser amigo, ser chefe e ser amigo ao mesmo tempo, que você precisa ter muito conhecimento pra você poder mandar; mas o mandar não significa impor a sua vontade com o seu funcionário mas dividir com ele, negociar com ele, participar, mostrar a minha vivência como supervisora, que eu nunca fui uma pessoa muito rude, que eles têm essa vivência

que eles trazem, de enfermeiro, como aquele que manda, aquele que briga.

Castanha-do-Brasil

Eu tento mostrar pra eles que não é assim, mas mostrando sempre a importância que você só vai ser um bom profissional se você tiver conhecimento, se você for humano, sempre mostrando o que eu sou como profissional; pelo menos o que eu imagino ser como profissional.

Castanha-do-Brasil

\section{A estrutura universitária dificultando a ação}

\section{docente}

Essa categoria foi apontada por apenas um dos docentes entrevistados. Nela declara que sua forma de trabalhar não vai ao encontro do que ele imagina ser uma docência ideal, por diversos aspectos como a necessidade de cumprir a carga horária de forma rigorosa, a dificuldade em mexer nos conteúdos programáticos, a falta de tempo para executar atividades como leitura, pesquisa, correção de provas, etc... Dessa forma, demonstra sentimentos de angústia, de insatisfação e até de culpa 


\section{mesmo, porém tentando fazer suas atividades da melhor maneira}

que pode.

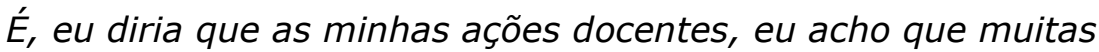
vezes elas acabam não se dando exatamente da forma que eu idealizo o docente, pela própria estrutura do curso ...

É um curso ... que você ... trabalha com produção. É assim que eu sinto o curso e, muitas vezes, eu me sinto frustrado em relação a isso. Porque você tem que cumprir carga, então, a carga horária, você tem que cumprir programa; você não tem uma flexibilidade de mexer muito nesse programa de acordo com o desenvolvimento da turma.

Jambo

... aqui, independente dos passos, você tem que puxar esse aluno para que ele caminhe nesses passos, que é um passo já determinado; é um programa para cumprir e esse programa tem que ser cumprido.

Jambo

E aí, assim, eu tenho outro em vista, tenho outros temas em vista que eu gostaria de estudar, de pesquisar, de escrever a respeito e na verdade; nessa roda viva eu não consigo, porque você não tem tempo hábil para nada.

Jambo

... aqui você tem seguir um padrão, que todo mundo tem que ouvir a mesma palavra. Então, se todo mundo tem que ouvir a mesma palavra, um prepara a aula e todos dão aquela mesma aula com todas as palavras.

Jambo

Então, assim, por isso eu digo, é um ritmo de produção; eu não tenho tempo para pensar. 
Eu tenho que, simplesmente, usar o material do meu colega que já tá pronto.

Jambo

E então, assim, é um ritmo de muita loucura; eu não tenho muito tempo para pensar; é ... em como está acontecendo esse processo todo. Eu só tenho que dar conta do processo.

Jambo

Então, assim, hoje, por exemplo, a minha situação é assim:" eu estou dando conta? Não, não estou! "Eu tenho muitas provas pendentes para corrigir, que eu não consegui dar conta de corrigir as provas justamente por causa desse toque de caixa que a gente trabalha.

Jambo

Isso me gera uma sensação às vezes de desconforto, de opressa; às vezes um sentimento meio de culpa, porque você deixa pendente algumas coisas ...

Jambo

A questão da orientação do TCC, por exemplo, grupos muito grandes, eu oriento um grupo comcinco alunos, é complicadíssimo; você trabalhar grupos muito grandes de orientação de TCC porque a orientação individual já é um problema; com cinco, pior, muito mais difícil.

Jambo

Então, dar TCC no segundo semestre é isso que acontece. É como adotar uma criança que você não sabe o que vai dar depois. Jambo

Então eu acho que, assim, eu acabo vivendo um pouco essa roda viva, justamente por conta disso.

Jambo

Eu vejo assim; eu procuro fazer o melhor possível; procuro sempre acertar da melhor forma, mas ainda entendo que muitas coisas acabam ficando pendentes nesse processo todo. 


\section{O trabalho multidisciplinar}

Praticam suas ações dessa maneira pois acreditam na importância do trabalho multidisciplinar e que este trabalho conjunto deva ser sustentado por um planejamento de todo o corpo docente no início dos semestres para que haja uma integração dos conteúdos.

Então, a gente foca o curso todo sempre tentando fazer um conjunto com as disciplinas clínicas, semiologia, por exemplo, aonde busque as necessidades das disciplinas básicas da anatomia.

Acerola

Aí eu encontro com essa aluna outra vez e ela fala: "Olha, estou usando sua matéria agora para fazer um trabalho do professor $X^{\prime \prime}$. Então, quer dizer, ela está usando o que foi oferecido antes; ela está usando agora, e esse mesmo é o meu intuito.

Açaí

Como é que a gente pode estimular a leitura? Através da sua disciplina e é importante também a ação docente, que eu acho essencial no ensino superior é o intercâmbio entre as disciplinas, porque hoje em dia não dá para ficar só a disciplina

isolada.

Açaí

A disciplina isolada perde muito e a gente vê que a gente tem a ganhar muito quando a gente faz um intercâmbio com as outras disciplinas, por exemplo: no início do ano, a gente fez uma reunião com outras disciplinas do mesmo período em que, por exemplo: a preventiva trabalha questões do ciclo vital também, e aí a gente procura no mesmo momento eu estar abordando a nutrição no ciclo vital nesses mesmos momentos que a informação preventiva aborda essas questões. 
Então, são momentos em que são essenciais, que haja a integração dessas disciplinas, porque só possibilitar que o aluno por si faça essa integração é pouco.

Açaí

Eu acho que a gente mesmo, entre os professores, tem que haver essa integração aí dessas disciplinas; no mínimo nas que ocorrem no mesmo período, no mesmo momento para o aluno; mas também tem oportunidade de trazer a contribuição em outra disciplina como convidada, como uma aula específica e tal. Hoje, no ensino superior, o aluno tem essas dificuldades por ser aluno trabalhador que não tem tempo para estudar.

Açaí

Então eu exijo muito deles nesse sentido, que tem que ser bom tecnicamente e pra isso precisa estudar. Eu mostro isso pra eles o tempo todo e tento mostrar assim, de uma maneira até respondendo perguntas de outras disciplinas, mostrando pra eles que o conhecimento da gente é um conhecimento inteiro, não é só de uma determinada especialidade, que o profissional tem que ter uma outra vivência.

Castanha-do-Brasil

O fato de eu estar dando Didática esse ano tá fazendo eu mudar ainda mais esse lado de mostrar mesmo pra eles que o profissional bom é aquele profissional inteiro.

Castanha-do-Brasil

\section{A própria formação docente}

Relatam suas experiências, mas demonstram uma inquietação quanto à sua formação como docentes. Vivenciam uma crise de identidade profissional, pois encontram-se divididos entre sua formação na área de saúde e o fato de estarem atuando, no momento, como docentes. 
Então, quando eu entrei aqui, eu já tinha um pouquinho de experiência na docência; mas quando eu iniciei na docência, eu tinha o conhecimento sobre a disciplina que eu ministro, que é a nutrição para a enfermagem, como eu sou nutricionista.

Açaí

Acho que assim, uma coisa que eu tenho repensado ultimamente é assim: se eu sou enfermeira ou se eu sou professora. Acho que eu estou numa crise nesse momento de querer ser boa professora mas ainda achar que sou enfermeira.

Castanha-do-Brasil

Então, acho que essa coisa de formação docente é uma coisa que agora está pegando.

Castanha-do-Brasil

Sempre que falo que agora eu sou só professora, que é o que eu falo, as pessoas falam: "agora você não trabalha; você só dá aula!" como se fosse fácil, né ? Eu tenho que me preocupar um pouquinho com essa formação docente.

Castanha-do-Brasil

Então eu tenho lido algumas coisas, tenho procurado algumas coisas pra tentar ver se eu sou mesmo professora ou se eu sou uma enfermeira brincando de professora porque eu estou num momento de reflexão nesse sentido.

Castanha-do-Brasil

\section{O trabalho em equipe}

Apenas um docente não enfermeiro abordou a importância do trabalho em equipe na formação do enfermeiro.

Bom, basicamente a gente trabalha nas atividades práticas, a gente tenta sempre manter entre os alunos um instinto de cooperação para que eles trabalhem em equipe. 
Então, de forma que a gente coloca o conteúdo e faz com que eles rodem nas bancadas sempre em grupos diferentes, para eles estarem sempre trocando opiniões, trocando informações, para facilitar a integração porque a gente acredita, que nesse campo, ele vai trabalhar sempre dentro de uma equipe, e a troca de informações vai ser muito importante.

Acerola

\section{Avaliação}

A avaliação é um assunto de extrema relevância dentro do processo educacional. Foi abordado de forma tímida nas entrevistas, fazendo-se presente em apenas um discurso de um docente não enfermeiro. Explicita a necessidade de uma avaliação formativa, a qual é realizada no decorrer de um programa instrucional propondo-se a aperfeiçoá-lo em detrimento da avaliação somativa, como um processo de avaliação final de um programa instrucional visando julgá-lo.

... e aí, ao final, o critério que a gente tem de avaliação é pra não avaliar só no final, pra avaliar o processo; e hoje também o que está sendo preconizado em termos de avaliação, é você avaliar o processo como um todo e não só ao final de um período.

Açaí

Então a gente, no processo, chega a avaliar a capacidade de síntese que eles têm ao fazer um resumo. Por exemplo, a gente atribui nota - também é uma avaliação - fazer um resumo e depois também fazer a parte de referência bibliográfica. 
Mas nada impede - e eu também aprendi isso no mestrado. No mestrado a gente tem tido contato com essas questões que envolvem a educação no ensino superior, desde a avaliação, as estratégias de ensino, então, como a gente pode aplicar isso.

Açaí

Ao encerrar a apresentação das categorias concretas do vivido, para que se torne mais clara a compreensão do fenômeno a ser desvelado, apresento a seguir o esquema I, representativo dos motivos para e dos motivos porque, extraídos dos discursos. 
ESQUEMA I - Motivos porque e motivos para extraídos dos discursos dos docentes enfermeiros e docentes de outras áreas da saúde.

\begin{tabular}{|c|c|}
\hline $\begin{array}{l}\text { MOTIVO } \\
\text { PORQUE }\end{array}$ & $\begin{array}{l}\text { MOTIVO } \\
\text { PARA }\end{array}$ \\
\hline $\begin{array}{l}\text { O aluno como futuro } \\
\text { profissional }\end{array}$ & $\begin{array}{l}\text { O aluno como futuro } \\
\text { profissional }\end{array}$ \\
\hline Crescimento pessoal do aluno & Crescimento pessoal do aluno \\
\hline O docente como pesquisador & O docente como pesquisador \\
\hline Os conteúdos & Os conteúdos \\
\hline Sentimentos distintos & \\
\hline O perfil do aluno & \\
\hline Visão do que é ser docente & \\
\hline As estratégias de ensino & \\
\hline $\begin{array}{c}\text { MOTIVO } \\
\text { PORQUE } \\
\text { (em menor freqüência) }\end{array}$ & \\
\hline $\begin{array}{l}\text { Relação interpessoal } \\
\text { professor-aluno }\end{array}$ & \\
\hline $\begin{array}{l}\text { A estrutura universitária } \\
\text { dificultando a ação docente, }\end{array}$ & \\
\hline O trabalho multidisciplinar & \\
\hline A própria formação docente & \\
\hline 0 trabalho em equipe & \\
\hline A avaliação & \\
\hline
\end{tabular}




\section{CONSTRUÇÃO DO TIPO VIVIDO}

Para que pudesse ser descrito o tipo vivido do comportamento social dos atores deste estudo, foi necessário resgatar as intenções desses sujeitos extraindo as convergências de seus significados.

Os dois sujeitos estudados - docentes enfermeiros e docentes de outras áreas da saúde -, apresentaram reciprocidade de intenções, visto que vivenciaram um mesmo cenário social e compartilhavam experiências semelhantes em suas ações docentes.

As categorias emergentes do vivido, manifestadas pelos atores sociais que este estudo pesquisou, refletiram uma visão congruente quando partilhavam de uma mesma relação face a face. Nessa relação, onde suas experiências aconteciam num mesmo tempo e espaço e demonstravam possuir consciência quanto as outras pessoas.

Sendo assim, tive a possibilidade de descrever o tipo vivido dos docentes enfermeiros e docentes de outras áreas da saúde que atuam no Curso de graduação em Enfermagem. O tipo 
vivido mostra aquele docente que vê o aluno como futuro profissional, e para isso, procura fazê-los refletir sobre seus saberes, suas habilidades e suas atitudes; aquele que espera que ele não só tenha capacidade de pensar de forma crítica, que saiba tomar decisões, que questione sua própria prática, mas que também seja tecnicamente competente. Ainda espera ver um profissional que seja humanizado e com capacidade de trabalhar em equipe. Deseja ainda colaborar no crescimento pessoal do aluno auxiliando-o não só na sua qualificação técnica, como igualmente ajudando-o a ser uma pessoa mais bem capacitada do ponto de vista intelectual, cultural; que se aprimore nas relações interpessoais e que saiba exercer uma boa liderança frente à sua equipe. Da mesma maneira acredita que ser docente é ser pesquisador, ressaltando sua responsabilidade em fazer o aluno adquirir um olhar investigativo; isso se torna possível por meio do Trabalho de Conclusão de Curso e dos projetos de Iniciação Científica. É, ainda, um docente que tem a intenção de fornecer os conteúdos programáticos propostos pela disciplina, esperando que haja domínio desse conteúdo por parte dos alunos; são conteúdos que irão fortalecer a base de conhecimentos desses futuros profissionais. Atuam como docentes vivenciando diferentes sentimentos que transitam entre positivos e negativos. Positivos: satisfação, prazer e gratificação no relacionamento que 
estabelecem com os alunos. Negativos: insatisfação, angústia, desprazer, frustração, sobrecarga de trabalho, ansiedade, decepção, conflito e inadaptação ao meio. Age também tendo visão de que ser docente é acreditar na valorização e respeito à diversidade de alunos; e assim, acredita que é possível trabalhar as dificuldades apresentadas pelos alunos a partir de suas vivências. Mostra preocupação em fazer um ensino que possa vincular a teoria com à prática através da experiência profissional do professor. Atua junto a alunos com um perfil traçado por uma bagagem de conhecimentos e experiências extremamente heterogêneas; porém, nos dizem que mesmo com diversas dificuldades detectadas, apresentam também inúmeras possibilidades que podem ser exploradas pelos professores. Os docentes demonstram grande preocupação e interesse em diversificar as estratégias de ensino levando os alunos a constantes questionamentos sobre os conteúdos, despertando sua curiosidade científica e exercitando habilidades diferenciadas. 


\section{8}

\section{ANÁLISE COMPREENSIVA}

O referencial filosófico de Alfred Schütz alicerça a análise compreensiva dos motivos para e dos motivos porque, que emergiram das categorias concretas do tipo vivido dos docentes enfermeiros e dos docentes com formação em outras áreas de saúde que atuam no curso de graduação em Enfermagem.

Todos eles - que se prestaram a este estudo - vêem - aluno como um futuro profissional e por esse motivo, manifestam sua preocupação em formar um enfermeiro que reflita sobre seus saberes, suas habilidades e suas atitudes. De igual modo, demonstram o cuidado para que tenha capacidade de pensar de forma crítica, de saber tomar decisões, de questionar sua própria prática, sem deixar de lado a competência técnica. Ainda espera um profissional que seja humanizado e com capacidade de trabalhar em equipe.

Isso implica no docente organizar seus conteúdos de maneira específica para cada curso que ministra, vislumbrando a sua utilidade na carreira desses alunos. Também se faz necessária a prática de reflexão, junto a esses alunos, sobre suas vivências e seu papel no contexto da equipe multidisciplinar. Valorizam eles a 
idéia de fazer um ensino que seja significativo para a vida pessoal e profissional de cada um.

É fato notório que jamais, na história da humanidade, o ser humano foi tão testado e posto à prova como nos dias de hoje. Em plena era de globalização e da informática, passará pelo teste - e irá ocupar seu espaço na sociedade - todo aquele que souber, exatamente o que deseja alcançar e usar a força de sua inteligência e capacidade para abrir novos caminhos e chegar aonde deseja.

Nesse panorama, Nóvoa (1999) avalia que, cada vez mais, há uma retórica crescente sobre o papel fundamental que os professores tem quanto à formação dos novos profissionais e conseqüentemente quanto à construção da sociedade do futuro, resultando, portanto, no desempenho do seu novo papel.

Com relação à necessidade e importância de vincular a sal de aula ao dia a dia do educador, Antunes (2002) considera que é preciso um grande esforço do docente nessa direção, uma vez que a informação isolada não tem significado algum.

Quanto ao papel do professor, Pimenta (1999), admite que o docente deve intermediar os processos constitutivos da cidadania dos alunos. Refere pouca eficiência à formação inicial 
e contínua desses professores e critica-os por não refletirem sobre a prática docente e pedagógica nos seus contextos.

A competência também é um quesito que faz parte do papel do professor. Macedo (2002), diz que cabe ao docente agir com competência, ou seja: saber tomar decisões; significa fazer escolhas, julgar, avaliar o que é melhor (em termos de nossas referências ou valores); correr riscos, utilizar conhecimentos ou informações como elementos importantes nesse processo; saber argumentar, enfrentar situações-problema, elaborar propostas, compreender fenômenos; participar, enfim, como sujeito ativo em um sistema complexo; mobilizar recursos e ativar esquemas (revendo ou atualizando hábitos) em um contexto de complexidade.

É imprescindível, pois, que se identifiquem as competências docentes necessárias para se fazer aprender num universo de públicos escolares heterogêneos e cercados de outras dificuldades que permeiam o processo ensino-aprendizagem, como, por exemplo, o absenteísmo, a crise econômica e as transformações nas relações humanas.

Chauí (2003) ensina:

Há formação quando há obra de pensamento e este se realiza quando o presente é apreendido como aquilo que exige de nós o trabalho da interrogação, da reflexão e 
da crítica, de tal maneira que nos tornamos capazes de elevar ao plano do conceito o que foi experimentado como questão, pergunta, problema ou dificuldade.

As novas exigências no mundo do trabalho vieram mudar paradigmas buscando-se menos produtividade e mais competitividade, menos informação e mais conhecimento, menos treinamento e mais educação.

Nesse sentido, nunca é demais insistir na importância dos requisitos que fazem parte do papel do professor. Assim, num mundo em transformação, a ascensão social e econômica é um desafio, sendo indispensável um perfil de eterna construção e transformação. Some-se a esses requisitos a habilidade de enfrentar crises e mudanças repentinas, pois quem não tiver a mente aberta para as novidades do mercado de trabalho, ficará perdido e sem rumo na vida profissional.

Concluímos que o profissional deste século recéminiciado precisará inovar sempre acreditando no seu potencial, fortalecendo seus pontos fracos, usando com maestria suas habilidades natas.

Com a convicção sobre estes pressupostos, registro algumas qualidades do trabalhador do século XXI, referendadas pela UNESCO e que nos conduzem a uma profunda reflexão sobre nós mesmos. São elas: flexibilidade, criatividade, informação, 
comunicação, responsabilidade, empreendedorismo, socialização e tecnologia.

Faz-se necessário construir de uma identidade docente que satisfaça a demanda e as carências de uma sociedade. É uma construção que precisa ser feita de acordo com seu contexto; para isso, mobilizar os saberes é, então, o primeiro passo no processo de construção dessa identidade na sociedade atual, como garante Pimenta (1999).

Por conseguinte, é de grande importância a formação inicial voltada para a aquisição de conhecimentos e habilidades, de atitudes e valores, que permitam a construção dos "saberesfazeres" docentes na prática do cotidiano.

De igual modo, é importante o desenvolvimento da capacidade de investigação da própria atividade para, a partir dela, transformar os "saberes-fazeres" docentes, num processo contínuo também de construção de uma nova identidade.

Os saberes da experiência dizem respeito à bagagem que os professores trazem; envolvem as suas experiências enquanto alunos na visão que tinham sobre seus docentes. São experiências adquiridas, pelo conceito social, político e financeiro da profissão docente, por atividades já desenvolvidas em sua 
carreira e pela reflexão das suas práticas do cotidiano (Pimenta e Anastasiou, 2002).

Os saberes devem ser considerados, a um só tempo, ponto de partida e ponto de chegada para essa reflexão e fundamentais na construção do processo identitário do docente (Pimenta e Anastasiou, 2002).

Além do mais, os saberes do conhecimento são os que permitem a discussão em torno desses conhecimentos no contexto da contemporaneidade. Eles possibilitam aos alunos o trabalho com os conhecimentos científicos e tecnológicos, desenvolvendo habilidades para operá-los, revê-los, confrontá-los e contextualizá-los. Desse modo, a ênfase deve recair no conhecimento e não apenas na informação.

A esse respeito observa-se que uma concepção de conhecimento supõe, entre outros fatores, a relação sujeito (aluno) - objeto (conteúdo), numa interação dinâmica e permanente, que se torna mais rica e efetiva de acordo com a atitude de mediação do professor.

Pimenta e Anastasiou (2002) consideram que conhecimento é o estágio posterior ao da informação, implicando trabalhar com as informações anteriores, classificando-as, 
analisando-as e contextualizando-as. Esse conhecimento relacionase com a inteligência e gera novas formas de conhecer, úteis e pertinentes para uma sociedade sedenta e carente de novos saberes.

De um modo especial, o saber pedagógico abrange o conhecimento aliado à experiência e aos conteúdos específicos que serão construídos a partir das necessidades pedagógicas reais.

Trata-se, como esclarecem Pimenta e Anastasiou (2002) do "saber que o professor constrói no cotidiano de seu trabalho e que fundamenta sua ação docente, ou seja, é o saber que possibilita ao professor interagir com seus alunos, na sala de aula, no contexto da escola onde atua".

E continua Pimenta: "Trabalhar o conhecimento na dinâmica da sociedade multimídia, da globalização, da multiculturalidade, das transformações nos mercados produtivos, na formação dos alunos, também eles em constante processo de transformação cultural, de valores, de interesses e necessidades, requer permanente formação, entendida como ressignificação identitária dos professores".

O "processo identitário", acrescenta Morin (1999), "se constrói com base nos significados sociais da profissão, da 
revisão das tradições, pelo significado que cada professor como autor e ator confere à atividade docente em seu cotidiano, por meio da discussão da questão do conhecimento como ciência e da construção dos saberes pedagógicos"

"É preciso pensar que o educador competente é um educador comprometido com a construção de uma sociedade justa, democrática, na qual saber e poder tenham equivalência enquanto elementos de interferência no real e organização de relações de solidariedade, e não de dominação, entre os homens" (Morin,1999).

Pelo testemunho desse autor, podemos perceber sua referência no campo da ética Assim sendo, resgatar a significação da dimensão técnica e política pela mediação da perspectiva ética abre a possibilidade de enfocarmos o novo papel do docente no ensino superior.

Estendendo-se pela análise da área pedagógica, Perrenoud (2001), diz que não se forma um profissional reflexivo impondo-Ihe condições ortodoxas de dar aula, e que a formação do professor ainda está em busca de seu caminho no contexto das universidades. 
Portanto, ressignificar a identidade do docente nos reporta a uma análise que permeia desde a formação desses profissionais até os saberes necessários à prática pedagógica.

Porém, o progresso do saber docente só será possível se for realizado de forma simultânea com o seu desenvolvimento pessoal e com apoio e incentivo institucional. Quanto ao apoio institucional, ele pode ser considerado como um verdadeiro desafio na construção da docência no ensino superior.

Todas essa análises fazem parte de um processo que deve ser discutido na coletividade do corpo docente. Isso provoca um conhecimento e um crescimento mútuo entre os pares e a filosofia da instituição e possibilita um avançar na prática docente.

No caso dos sujeitos submetidos a este estudo, além de desejarem contribuir na formação de um profissional qualificado tecnicamente, esperam poder ajudá-lo a se tornar uma pessoa mais bem capacitada também do ponto de vista intelectual e cultural. Esperam possibilitar um aprimoramento nas relações interpessoais e uma aprendizagem de como exercer uma boa liderança frente à sua equipe. São características essas necessárias para um mercado de trabalho cada vez mais exigente e competitivo. 
Assim, os docentes pesquisados caminham na direção de formar um aluno-profissional que possa ser competitivo no atual mercado de trabalho, numa demonstração de quem acredita na valorização de pessoas possuidoras de atributos humanos tão bem desenvolvidos quanto as qualidades acadêmicas e profissionais.

Procuram explicitar a importância de valores como respeito e solidariedade contextualizando o ensino no universo dos alunos. Buscam fazer a docência de forma holística, na tentativa de ajudar esses alunos a enfrentarem a vida de forma plena e equilibrada.

A reflexão sobre os relatos dos docentes me fizeram perceber que eles descrevem os conceitos de ação de Alfred Schütz. Para esse filósofo, a ação é vista como uma conduta sustentada em projetos, naquilo que se pretende alcançar. Ela está voltada para o futuro; são as intenções dos sujeitos e, por isso, é interpretada pela subjetividade dos atores.

O modo com que as pessoas ocupam o espaço de suas ações é determinado pela influência do meio sociocultural no qual estão inseridas. A idealização desses atos está fundamentada na situação biográfica que é sempre única de cada ator. Dessa forma, a ação é sempre repleta de intencionalidade; estará 
direcionada para a realidade social onde os sujeitos estão transitando.

A projeção da idéia de ver o aluno como um futuro profissional está relacionada a situação biográfica de cada um dos docentes entrevistados no curso de Enfermagem.

Os entrevistados caracterizaram o perfil de seus alunos identificando, em uma grande maioria, experiência na área de enfermagem mesmo antes de sua inserção na universidade. Exercem as funções de auxiliares e técnicos de enfermagem, com uma bagagem de conhecimentos extremamente heterogênea, revelando, assim, facilidades e dificuldades relacionadas com essas experiências. Porém, dizem que, mesmo com diversas dificuldades, apresentam também inúmeras possibilidades que podem ser exploradas pelos professores.

Nesse sentido, a literatura tem apontado algumas dificuldades. Por exemplo, que alunos trabalhadores que cursam a graduação de enfermagem apresentam características próprias como a restrição de tempo devido a um cotidiano assoberbado, dando a entender que as atividades de trabalho tomam a maior parte do seu tempo. Outro exemplo apontado: a necessidade de se trabalhar em um ou dois empregos durante toda a graduação para se manterem financeiramente nas universidades privadas somada 
a responsabilidade financeira pessoal e com terceiros (Iglesias, 2002)

Diante desses exemplos reais, justifica-se, então, a importância de um diagnóstico da realidade na qual estão inseridos nossos alunos de modo a serem um ponto de partida para que possamos redirecionarmos as práticas como docentes.

Para o docente, seu papel de colaborar na formação do aluno como indivíduo faz parte de suas competências, visto que o grupo, de alunos trabalhadores possui características diferentes de alunos não trabalhadores.

O que se espera, na era do conhecimento exacerbado é que aflore um novo aluno, com os seguintes atributos: sujeito da sua própria formação, autônomo, motivado para aprender, disciplinado, organizado, cidadão do mundo, solidário e, sobretudo, curioso. Porém, esta é uma receita que nem sempre vai ao encontro do aluno com quem deparamos no dia-adia na sala de aula.

Um outro desafio revelado nos discursos: apontaram um questionamento constante sobre o que é ser docente e uma preocupação em fazer um ensino que consiga relacionar a teoria com a prática através da experiência profissional do professor 
Sem dúvida, a atividade docente envolve, antes de tudo, o conhecimento específico da área profissional. Mas ensinar pode ser mais bem entendido se nos apropriarmos do significado etimológico do termo ensinar, que significa mostrar um caminho. Isso significa que a função da docência não é despejar informações sobre seus alunos, como se eles fossem destituídos de conhecimentos prévios resultantes de vivências anteriores.

Na seqüência da análise compreensiva dos discursos dos nossos entrevistados percebemos que eles demonstraram valorização e respeito à diversidade de alunos com os quais convivem nas salas de aula, e que têm uma percepção de que é possível trabalhar as dificuldades apresentadas pelos alunos a partir de suas vivências. Esses comportamentos nos fazem perceber que os educadores estão comprometidos com os interesses dos alunos. Valorizam a idéia de fazer um ensino que seja significativo para eles na vida pessoal e profissional.

O verdadeiro mestre indica caminhos, ou seja, ensina para que sejam adquiridos mais conhecimentos e desenvolvidas novas idéias. Suas tarefas exigem tolerância e sensibilidade para entender o processo que o aluno elabora dentro de si para compreender os fenômenos que se pretende ensinar. 
Ser bom docente, portanto, significa ter também uma dose de iniciativa individual, uma disposição pessoal para se envolver com o caminho da aprendizagem que o aluno está trilhando. Mas, como seres sociais e gregários que somos, podemos alcançar um pouco mais de disposição para a docência construtivista se nos dispusermos de boa vontade a aprender também, com os outros.

Estas considerações vêm ao encontro do pensamento de Rios (2002), que declara que o competente exercício da docência mescla técnica e sensibilidade orientadas por determinados princípios encontrados num espaço ético-político.

A partir daí, um questionamento se faz presente: ensinar bem os conteúdos, utilizando recursos adequados, significa dirigir-se para o objetivo desejável que é formar um cidadão consciente, reflexivo, crítico e atuante? A resposta a essa dúvida põem em evidência que deve existir um componente fundamental que precisa estar presente na dimensão ético-política: a intenção do gesto do educador. Assim, o que o educador decide fazer com o saber é extremamente relevante para que sua ação seja qualificada como competente (Rios, 2002).

É nessa medida que o educador contribui com seu "ensinar comprometido" com as transformações necessárias na 
sociedade. A vontade, articulada à consciência, mostra-se então como componente fundamental para a concretização desse processo. Como defende Rios ...

É preciso pensar que o educador competente é um
educador comprometido com a construção de uma
sociedade justa, democrática, na qual saber e poder
tenham equivalência enquanto elementos de interferência
no real e organização de relações de solidariedade, e não
de dominação, entre os homens (Rios, 2002).
Desse modo, todas essas considerações apontam o
caráter dinâmico da profissão como prática social, prática essa que se faz no cotidiano dos sujeitos nela envolvidos mostrando-se uma trama rica de possibilidades.

Nesse sentido, ressignificar a identidade do docente nos reporta a uma análise que o deverá acompanhar desde a sua formação como profissional até os saberes necessários à prática pedagógica.

Levando-se em conta o fato de que o professor é ainda absolutamente indispensável para atuar na aprendizagem, mostra-se clara a necessidade de estar estudando de forma mais profunda a competência docente na formação de alunos do curso de graduação em enfermagem.

Faria e Casagrande (2004) acreditam que formar um professor reflexivo no campo da enfermagem vai exigir uma 
redefinição em sua prática docente, em especial quanto ao desenvolvimento de certos saberes e competências que são destacadas como necessários no contexto do processo efetivo de ensino-aprendizagem. São suas estas recomendações:

- uma interação entre professor-aluno voltada para a consecução dos objetivos educacionais propostos, de co-responsabilidade pelo aprendizado, de parceria, de equipe, de diálogo e respeito entre pessoas adultas;

- alteração no espaço físico e circunstâncias do ambiente, permitindo maior interação e participação, em espaços físicos que possam criar interesse e motivação pelo ensino e aprendizado;

- Redefinição dos objetivos da própria aula, para que se torne uma oportunidade de debate entre professor e alunos, com análise de leituras e informações trazidas pelo grupo;

- implantação de técnicas participativas, devendo o docente refletir sobre como introduzir novas estratégias que possibilitem uma relação professor-aluno mais efetiva, na qual ambos trabalhem e construam o conhecimento juntos, criando motivação para o envolvimento dos alunos.

- alterar o processo de avaliação, que precisa ser pensado, planejado e realizado de forma integrada ao processo de ensino-aprendizagem e coerente 
com o que foi proposto. Isso inclui também assumir o erro como oportunidade de crescer, de uma retro-informação, que provém do professor, do aluno, dos outros alunos, e de outros elementos que possam estar participando do processo.

Dessa forma, procede destacar a importância da formação pedagógica para os docentes. Pois, apesar de serem especialistas em suas áreas de atuação - e aí eu me incluo -, lidar com as questões didático-pedagógicas é sempre um desafio a ser vencido, tornando-se enriquecedor para mestres e discípulos.

É essencial, nesse sentido, que as instituições que anunciam como principais valores o conhecimento e o ensino, promovam a formação continuada de seus docentes, o que representa a real valorização do profissional no campo da educação. Para que isso aconteça, é preciso ter também uma visão prática, que passa pelas reais ações de valorização do docente. Essas ações significam criar variadas oportunidades de formação contínua, oferecer programas de atualização docente e de aperfeiçoamento pedagógico, propor cursos de reciclagem científica, abrir possibilidade de constante participação em congressos e conferências e incentivo À pós-graduação por meio de bolsas de estudo. 
Nos depoimentos dos entrevistados, encontramos também nos depoimentos a percepção de que realizar pesquisa cientifica faz parte da ação docente.

Nessa categoria, eles declaram fazer parte de suas competências a orientação a trabalhos de pesquisa científica, como Trabalho de Conclusão de Curso e Iniciação Científica. Por outro lado, apontam igualmente algumas dificuldades que encontram no desenvolvimentos de projetos dessa natureza. De qualquer maneira, buscam despertar o olhar investigativo do aluno trabalhando através de um trabalho em parceria, tratando-os como colaboradores de todo o processo de ensinar e aprender.

Em relação aos programas a serem desenvolvidos, evidencia-se a intenção do docente de ministrar os conteúdos propostos pela disciplina e que haja domínio desse conteúdo por parte dos alunos, o qual deve ser o mais amplo possível, abrangendo as esferas do conhecimento, das habilidades e das atitudes, permitindo solidificar a base de conhecimentos dos futuros profissionais.

As falas desses discursos mostram uma ação docente voltada para a associação da prática-teoria-prática, fortalecendo assim seus saberes. Trabalham com conteúdos que sejam coerentes com a vida real, concretos e úteis, ricos de exemplos e 
voltados não só para os aspectos técnicos dos cuidados da saúde, como os aspectos humanos que envolvem esses cuidados.

Do ponto de vista da dimensão técnica, Libâneo (1998), esclarece que é preciso assumir o ensino como mediação: aprendizagem ativa do aluno com a ajuda pedagógica do professor é a nova atitude esperada do docente diante das realidades do mundo contemporâneo. Destaca que o ensino exclusivamente verbalista, a mera transmissão de informações, a aprendizagem entendida somente como acumulação de conhecimentos, não subsistem mais. Isso não quer dizer abandonar os conhecimentos sistematizados da disciplina, nem abrir mão da exposição teórica de um assunto.

O que se afirma é que o professor é o facilitador da relação ativa do aluno com a matéria. Isso significa transmitir os conteúdos próprios de sua disciplina e considerar os conhecimentos, a experiência e os significados que os alunos trazem à sala de aula, seu potencial cognitivo, suas capacidades e interesses, seus procedimentos de pensar, seu modo de trabalhar.

Masetto (2003), avalia que a forma de apresentar e tratar um conteúdo ou tema é aquela que, de fato, ajuda o aprendiz a coletar informações, relacioná-las, organizá-las, manipulá-las, discuti-las e debatê-las com seus colegas, com o 
professor e com outras pessoas. Deve-se agir dessa forma até chegar a produzir um conhecimento que seja significativo para o aprendiz, conhecimento que se incorpore ao seu mundo intelectual e vivencial e o ajude a compreender sua realidade humana e social, e mesmo a interferir nela.

A mediação pedagógica assim entendida coloca em evidência o papel de sujeito do aprendiz e o fortalece como ator de atividades que lhe permitiram aprender e alcançar seus objetivos. Dá também um novo colorido ao papel do professor e aos novos materiais e elementos com que ele deverá trabalhar para crescer e se desenvolver.

É o momento de organizar junto com a classe o conteúdo da disciplina relacionando os vários tópicos com a realidade profissional dos alunos.

Batista e Silva (2001) comentam que são freqüentes organizações inadequadas de conteúdos e de conhecimentos ministrados em momentos impróprios ou não contextualizados a uma possibilidade de aplicação a curto prazo. Asseguram que a seleção e organização dos conteúdos, devem, ajustar-se ao processo real de aprendizagem dos alunos. Além dos conteúdos cognitivos, cabe ao professor contemplá-los com as habilidades necessárias para o efetivo domínio desses novos conhecimentos. 
Ao processo de aprender precisam ser incluídos conhecimentos, habilidades e atitudes, devendo o professor estar atento para sua validade, ou seja, sua relação com os objetivos, seu valor prático, sua possibilidade de aplicação e sua ligação com conhecimentos anteriores do aluno, possibilitando 0 estabelecimento de correlações. Esses aspectos permitem realçar a importância da seleção dos conteúdos na construção sólida do conhecimento.

Acrescente-se que ainda é necessário optar por uma educação que não apenas valorize os conteúdos, mas que busque princípios de cidadania, de justiça social, de desenvolvimento da responsabilidade enquanto ser humano. Que não valorize apenas a avalanche de conteúdos programáticos, mas que caminhe na direção de despertar noções humanistas básicas.

Ainda quanto a análise compreensiva dos depoimentos, os docentes demonstraram significativa preocupação e marcante interesse em diversificar as estratégias de ensino que possa levar os alunos a questionamentos sobre os conteúdos, despertar sua curiosidade científica e exercitar habilidades diferenciadas. Nesse sentido, fazem uso do estudo dirigido, promovem discussões, propõem seminários, ministram aulas expositivas dialogadas. Tudo isso de acordo com o conteúdo a ser 
estudado, com o tempo disponível e com diversificadas condições organizacionais.

Não sem razão, Antunes (2002) salienta que, na sociedade da informação, professores devem dedicar-se mais a explorar contextos, habilidades e inteligências múltiplas e preocupar-se menos com softwares de última geração. Em contrapartida criticou também as maneiras tradicionais de trabalhar com os alunos e avaliá-los.

Segundo ele, as escolas deveriam

designar seus alunos por suas propriedades, não por suas ausências. Nos preocupamos em avaliar pelo máximo e não pelo ótimo, sem levar em conta as potencialidades dos alunos. Para o professor, os alunos deveriam ter $o$ direito de demonstrar seus conhecimentos nas mais variadas linguagens: música, teatro, desenho, etc. Antunes (2002)

Diz ainda que os professores deveriam dizer a seus alunos: "Fala na tua língua que eu saberei ler os teus saberes."

Porém, analisando a prática pedagógica atual, surge o questionamento perturbador no que se refere ao preparo dos docentes para colocar-se diante desta ótica. Estariam esses educadores preparados para isso?

De acordo com Macedo (2002), acha que ainda não. Suas palavras: 
... não suficientemente, pois nossa comunicação em sala de aula está prenhe de dilemas, ou seja, na rede complexa do sistema escolar estamos diante de encruzilhadas para as quais nossos saberes são insuficientes, muitas vezes, para nos ajudar a decidir, sem conflitos, pelo melhor caminho em direção aos nossos propósitos de ensino. Temos medos, há coisas que não dizemos, para as quais fazemos vista grossa, mas que no cotidiano da aula reclamam tomar decisões, correr riscos, mobilizar recursos nem sempre disponíveis (dentro e fora de nós), rever esquemas, hábitos, atitudes agora insuficientes para esses novos e complexos tempos de uma escola que se quer para todos, mas que não sabe incluir a todos.

Por outro lado, não é suficiente apenas questionar a prática pedagógica; é preciso que se criem situações de aprendizagem que respondam melhor à diversidade de carências dos educandos.

Para isso, comenta Perrenoud (2002), é necessário que educadores mobilizem o máximo de competências e façam o que for preciso para que possam ser construídas novas competências a curto ou médio prazo.

Esse educador acentua que "para fazer as práticas evoluírem, é importante descrever as condições e as limitações do trabalho real dos professores. Essa é a base de toda estratégia de inovação".

Nesse caso, é indispensável que seja feito um mapeamento das práticas, delineando uma imagem realista dos problemas com os quais os educadores se deparam todos os dias, 
um quadro dos dilemas que enfrentam,um esboço das decisões que tomam e dos gestos profissionais que realizam.

De igual modo, é preciso minimizar a dicotomia que existe entre a teoria e a prática mediante a criação de verdadeiras parcerias entre os docentes com o objetivo de formar um profissional reflexivo, crítico e autor de sua própria identidade profissional. Dessa maneira, os educadores estarão em condições de manter a coerência, o encadeamento e a continuidade na construção do saber dos educandos. Estarão ainda preparados para dialogar com os alunos sobre quais técnicas serão utilizadas nas aulas. Resultado do diálogo conduzirá ao desenvolvimento de técnicas que motivem os alunos diversificando a forma de aprender, incentivando a participação, explorando a possibilidade da interaprendizagem.

Rocha (1999), nos apresenta uma pesquisa em que um professor e alguns alunos tiveram a oportunidade de sugerir propostas de mudanças que julgavam importantes nas relações em sala de aula. Uma categoria que emergiu foi a necessidade de diversificação/inovação de métodos de ensino.

Esse fato concreto revela que o professor que decide modificar ou diversificar seus métodos de ensino, deve estar sempre se atualizando para que possa fazer essas mudanças com 
eficácia. Para isso, precisa realizar um trabalho em parceria com seus alunos de modo a criar espaços de construção de conhecimento coletivo, permitindo a participação ativa de cada um por meio de aulas a um só tempo interativas e atraentes.

Especificamente em relação ao curso de enfermagem, Peres (2001) analisou a percepção dos enfermeiros docentes quanto ao significado da inserção da informática no ensino da enfermagem. O cenário desvelado nos seus depoimentos permitiu a construção do tipo vivido de docente como sendo aquele que apresenta diferentes graus de interesse pelas novas tecnologias. É também aquele que visa a inserção da informática do ensino da enfermagem, vislumbrando projetos fundamentados em novos modelos pedagógicos que possibilitem aprendizado autoinstitucional e individualizado, numa perspectiva de formar enfermeiros críticos, reflexivos e tecnologicamente competentes.

Leite (2000), no seu estudo sobre as possibilidades e dificuldades da inclusão de tecnologias voltadas para o ensino de administração de enfermagem, põe em evidência que a implementação de novas estratégias tem íntima relação com a fundamentação do projeto pedagógico da escola. Quando este objetiva a formação de enfermeiros que sejam capazes de atuar no mercado profissional com autonomia, criatividade e criticidade, tais 
instrumentos devem contemplar estratégias de ensino que permitam aos alunos exercitarem essas habilidades.

Prado, Bitencourt, Souza e Pieroni (2004) estudaram as estratégias de ensino utilizadas por professores de um curso de graduação em enfermagem. Entretanto, o estudo mostrou que ao serem questionados sobre quais dificuldades encontravam ao procurar diversificar as estratégias, apontaram as seguintes: a existência de turmas com grande quantidade de alunos, recursos indisponíveis, dificuldade de participação do corpo discente; carga horária imprópria para a matéria; conteúdo não apropriado e falta de conhecimento de outras estratégias.

Importa, igualmente salientar que o preparo pedagógico do docente deve conduzi-lo a reconstrução de suas experiências, uma vez que possibilita uma nova visão de sua prática e, por conseguinte, mobiliza-o para a construção de novas formas de ensinar.

Todavia, essa dinâmica didática não segue uma receita mágica, isso significa que nenhuma estratégia é boa em si; vale dizer que nenhuma é melhor do que outra. Seu valor será sempre determinado pela possibilidade que ela oferece ao aluno de atingir um ou mais objetivos educacionais. 
Portanto, a escolha da estratégia de ensino supõe que o professor analise cuidadosamente os objetivos que ele pretende atingir, especifique os tipos de comportamento esperado dos alunos e faça um estudo detalhado das estratégias conhecidas e/ou disponíveis para verificar a adequação delas aos objetivos.

Não basta, enfim, apenas que se questione sobre a prática pedagógica; é preciso também que se criem situações de aprendizagem que respondam melhor à diversidade de professores e alunos e aos seus objetivos educacionais como asseguram Prado, Bitencourt, Souza e Pieroni (2004).

Dessa forma, para que aconteça uma aprendizagem nesses moldes, e por isso mesmo, verdadeiramente significativa, novos paradigmas têm que ser implantados nas salas de aulas e uma mudança no comportamento do professor no sentido de internalizar os seguintes pontos: acreditar que o aluno traz uma bagagem de conhecimento que não deve ser desconsiderada ao introduzir um novo conteúdo; introduzir conteúdos significativos e úteis para a vida do futuro profissional; adotar estratégias que provoquem a reflexão, o questionamento e a curiosidade científica, estimulando a auto-estima e dando-Ihes autonomia na busca do conhecimento. 
Freire (2001) nos alerta que ensinar supõe disponibilidade ao risco, aceitação do novo que não pode ser negado nem acolhido só porque é novo. Ensinar não aceita a rejeição a qualquer forma de discriminação, sob pena de negar radicalmente a democracia.

Porém, trilhar novos caminhos não será uma tarefa das mais fáceis, pois o professor que assim age encontrará resistência em algumas ocasiões por parte de alguns alunos, do próprio corpo docente e da coordenação do curso, caso eles não acreditem na necessidade e na importância da diversificação dos métodos de ensino.

Batista e Silva (2001) afirmam que "uma estratégia só terá êxito se o professor conhecê-la, assumi-la, acreditar nela e for capaz de usá-la". Esses pré-requisitos dizem respeito aos modernos meios de comunicação aplicados ao ensino. Nesse sentido, o professor deve considerar a importância da tecnologia educacional por ser um instrumento que possibilite a construção ativa do conhecimento pelo aluno, envolvendo a informação, o raciocínio e a correlação com outros conhecimentos. E o que é mais importante: o docente precisa saber que a tecnologia é um meio de aprendizado e não um fim. 
De qualquer maneira, devemos partir da premissa de que qualquer estratégia é válida desde que atenda aos objetivos traçados, ajudando o aluno a incorporar os novos conhecimentos de forma ativa, compreensiva e construtiva.

Na mesma linha da análise compreensiva, constatei ainda que, ao desenvolver suas ações no dia-a-dia da sala de aula, os sujeitos demonstraram vivenciar sentimentos distintos que transitavam entre satisfação, prazer, gratificação, facilidade na condução do seu trabalho.

A esse respeito Ohl (2002) buscou compreender a percepção das professoras da disciplina Enfermagem em Saúde do Adulto Institucionalizado no Curso de Graduação em Enfermagem quanto ao desenvolvimento de sua competência interpessoal na relação estabelecida com o aluno. Os resultados revelaram-se semelhantes aos obtidos neste estudo, ou seja, pôde identificar sentimentos variados - porém relacionados a sua atuação no campo de estágio - prazerosos ou conflitantes. Esses sentimentos foram explicitados sob a forma de satisfação, tranqüilidade, responsabilidade, incerteza, insegurança e frustração. Ainda mostraram-se muitas vezes insatisfeitos com as relações estabelecidas em sala de aula em decorrência da indisciplina gerada pelos participantes de todo o processo educacional. 
Prado C, Ferreira EM; França L. Barbieri JA. (2004) buscaram conhecer, entre alunos do curso de graduação em enfermagem, a opinião deles sobre a indisciplina vivenciada na sala de aula. Na análise dos dados, emergiram quatro categorias, que foram consideradas pelos alunos como possíveis focos de indisciplina: o professor, o aluno, a instituição e a família, cabendo a cada um desses elementos a sua importante parcela de contribuição no sentido de eliminar ou minimizar as situações indesejáveis na sala de aula da universidade.

São fatos que dão a entender, então, a necessidade de redimensionar a situação vislumbrando novos caminhos nas relações pedagógicas. Mais uma vez fica evidente que a questão central está na necessidade de mudança de paradigmas dos principais atores do processo ensino-aprendizagem: professores e alunos.

Nessa perspectiva, o professor como organizador do trabalho em sala de aula e coordenador da dinâmica de ensinar e aprender deve assumir seu papel de agente histórico de transformação da realidade, por meio de um ensino exigente e inteligente para se realizar a construção do conhecimento.

Num caminhar de emancipação e autonomia crescente, o aluno, de sua parte, deve ter consciência de sua 
responsabilidade no processo de aprendizagem individual e coletiva.

Em função de todas as considerações e análises compreensivas até aqui expostas e tendo como referencial o pensamento de Schütz, cheguei à compreensão dos docentes enfermeiros e dos docentes de outras áreas da saúde na sua maneira de atuar na prática de ensino bem como dos motivos para atuarem em suas realidade vividas. Essas análises fizeram emergir o significado das suas ações para eles, sendo um conhecimento de origem social e socialmente aprovado.

Os sujeitos declararam suas ações típicas do seu cotidiano como docentes de uma faculdade de enfermagem, tendo por base o estoque de conhecimento para entender e projetar as suas ações nesse contexto social. 


\section{9}

\section{VISLUMBRANDO CAMINHOS NA DOCÊNCIA}

Ao encerrar este estudo, acredito ser importante destacar que minha intenção ao realizar a pesquisa, ou seja, concretizar o meu motivo para, foi compreender as ações e os projetos dos docentes enfermeiros e dos docentes de outras áreas da saúde no contexto de um Curso de Graduação em Enfermagem. Para tanto, sustentei minha análise na perspectiva da fenomenologia de Alfred Schütz.

Essa compreensão foi facilitada pelo fato de eu também ser docente, de fazer parte do mesmo cenário social dos sujeitos do estudo e de ter uma situação biográfica semelhante.

A compreensão do vivido dos sujeitos me permitiu apreender a reciprocidade e a intersubjetividade que permearam os discursos dos docentes do Curso de Graduação em Enfermagem, no que diz respeito aos motivos para e motivos porque da prática docente.

O fenômeno desvelado nas falas dos sujeitos possibilitou a construção do mesmo tipo vivido dos docentes enfermeiros e de outras áreas da saúde: construção de um ideal, como aquele que vê o aluno como futuro profissional, que deseja 
colaborar no crescimento pessoal do aluno, que acredita que ser docente é ser pesquisador e que tem ainda a intenção de fornecer os conteúdos programáticos propostos pela disciplina, esperando que haja domínio desse conteúdo por parte dos alunos, os quais irão fortalecer a base de conhecimentos desses futuros profissionais.

Possibilitou ainda revelar a preocupação dos docentes com sua a formação didático-pedagógica além da sua apropriação dos saberes em seus aspectos éticos e políticos, sua formação contínua. Preocupação também com a necessidade de participar de programas de atualização docente e de aperfeiçoamento pedagógico e com a possibilidade de constante presença em congressos e conferências.

Declararam ainda em seus discursos que, muitas vezes, não se sentiam valorizados pela instituição na qual trabalhavam, motivo de um descontentamento pessoal e profissional que deve ser levado em consideração quando analisamos suas ações e seus projetos forem analisados.

O fato de termos constatado o mesmo tipo vivido dos docentes enfermeiros e dos docentes das demais áreas da saúde, provavelmente se deu por fazerem parte de um mesmo mundo 
social dando a entender convergências na intencionalidade deles ao praticarem e projetaram as suas ações.

Uma outra evidência ficou constatada: ser docente é fator determinante na ação desses sujeitos, independentemente de sua formação acadêmica. Eles vivenciam a intersubjetividade na relação face a face, tendo surgido então uma só tipificação, pois verificamos que há reciprocidade nas falas dos entrevistados demonstrando uma atitude natural semelhante entre eles.

De igual modo ficou transparente a necessidade premente de rever a competência didático-pedagógica, visto que os docentes colocaram em seus depoimentos que se sentem capacitados em suas áreas de conhecimento, mas não em relação a ampla função de ser docente.

Para tanto, é essencial a real valorização do profissional pelas instituições de ensino superior qualificando seus docentes, criando espaços e momentos formais para discussões das questões educacionais, possibilitando um fortalecimento de sua bagagem de conhecimentos e colaborando para a realização profissional de cada um.

Deixo aqui declarada minha firme crença de que é necessária uma revisão da identidade do docente universitário, 
particularmente na área de Enfermagem, que é o nosso cenário social atual em que ele trabalha. Para isso, é importante que os próprios docentes, de um lado, desejem refletir sobre seu papel e de outro, que as universidades promovam oportunidades para essa reflexão.

Nesse caso, refletir significa que esses docentes devam questionar-se se a filosofia da instituição e o projeto político- pedagógico de seus cursos têm vindo ao encontro de seus projetos pessoais, de suas perspectivas; ou ainda se estão vindo ao encontro do que a literatura preconiza para o ensino superior deste novo século e do perfil de alunos com o qual convivem todos os dias na sala de aula.

Considero que este estudo possa contribuir para ampliar o conhecimento da linha de pesquisa Políticas e práticas em educação e enfermagem, na medida em que aponta que as ações e os projetos dos docentes enfermeiros são semelhantes às ações e os projetos dos demais docentes da área da saúde. O que identifica esses dois sujeitos é o fato de terem um ponto importante em comum: todos eles são docentes de um curso de graduação na área da saúde.

Da mesma forma, o estudo me induz a afirmar outro fato: a reciprocidade das ações desses sujeitos reforça a 
importância da composição de um corpo docente multiprofissional, validando o conceito da interdisciplinaridade no projeto políticopedagógico. Esse dado, pois, desmistifica a idéia de que o fazer dos docentes enfermeiros é diferente do fazer dos docentes de outras áreas da saúde já que ambos possuem o mesmo tipo vivido no cenário deste estudo, como foi desvelado.

Os resultados mostram igualmente, de suma relevância implementar estudos que analisassem se a ações de um corpo docente multiprofissional vêm ao encontro das intenções dos coordenadores dos respectivos cursos de Enfermagem; em outras palavras se existe reciprocidade entre os coordenadores e seu corpo docente e se existe reciprocidade entre todos esses sujeitos e a proposta do projeto político pedagógico da escola.

Uma vez chegado ao fim deste presente trabalho, pode-se também tirar como conclusão a viabilidade de continuar este estudo em outros cenários - como, por exemplo, a outra universidade onde leciono-, para verificar a possibilidade de convergências e de divergências comparando-as com os resultados aqui expostos.

Uma última reflexão de caráter pessoal me fez concluir que a convivência com os sujeitos deste estudo, através de seus discursos, permitiram uma imersão nas minhas próprias 
ações, contribuindo de forma significativa para a construção do meu ser-docente.

Concluo admitindo que meus motivos para, a partir deste estudo, estão direcionados para a busca de um pensar e um fazer que abranjam as competências técnicas, ético-politicas, interpessoais e de um olhar para o corpo docente que revela a mesma intencionalidade no seu agir, pois minha situação biográfica de ser docente reivindica essas percepções e esses saberes. 


\section{REFERÊNCIAS BIBLIOGRÁFICAS}

Antunes C. Como desenvolver as competências em sala de aula. Petrópolis: Vozes; 2001.

Antunes C. Novas maneiras de ensinar, novas formas de aprender. Porto Alegre: Artes Médicas; 2002.

Arantes CIS. Saúde coletiva: os (des) caminhos da construção do ensino de enfermagem [tese]. São Paulo (SP): Escola de Enfermagem da USP; 1999.

Batista NA, Silva SHS. O professor de medicina: conhecimento, experiência e formação. São Paulo: Loyola; 2001.

Braga EM. Competência em comunicação: uma ponte entre o aprendizado e o ensino de enfermagem. [tese]. São Paulo (SP): Escola de Enfermagem da USP; 2004

Campoy MA. O ensino de enfermagem em saúde mental e psiquiátrica: uma visão da fenomenologia social [tese]. São Paulo (SP): Escola de Enfermagem da USP; 2003.

Capalbo C. Metodologia das ciências sociais: a fenomenologia de Alfred Shcütz. Londrina: UEL; 1998.

Cavalcante MBG. Humanização no processo de formação de profissionais de saúde: experiências de alunos do Curso de Graduação em Enfermagem [tese].São Paulo (SP): Escola de Enfermagem da USP; 2003.

Chauí M. A universidade pública sob nova perspectiva. Rev Bras Educ 2003; (24):5-15. 
Demo P. A criança é um grande pesquisador [online]. Disponível em: www.educacional.com.br/reportagens (24 maio 2002).

Esperidião E. Holismo só na teoria: a trama dos sentimentos dos acadêmicos de sobre sua formação.[tese]. Ribeirão Preto: Escola de Enfermagem da USP; 2001.

Faria JIL, Casagrande LDR. A educação para o século XXI e a formação do professor reflexivo na enfermagem. Rev Lat Am Enferm 2004; 12(5):821-7.

Freire P. Pedagogia da autonomia: saberes necessários à prática educativa. São Paulo: Paz e Terra; 2001.

Freitas GF. Ocorrências éticas de enfermagem: uma abordagem compreensiva da ação social [tese]. São Paulo (SP): Escola de Enfermagem da USP; 2005.

Fustinoni SM. As necessidades de cuidado da parturiente: uma perspectiva compreensiva da ação social [tese]. São Paulo (SP): Escola de Enfermagem da USP; 2000.

Gardner H. Estruturas da mente: a teoria das inteligências múltiplas. Porto Alegre: Artes Médicas Sul; 1994.

Gualda DMR, Merighi MAB, Oliveira SMJV. Abordagens qualitativas: sua contribuição para a enfermagem. Rev Esc Enferm USP 1995; 29(3):297-309.

Iglesias RB. Qualidade de vida alunos-trabalhadores que cursam a Graduação em Enfermagem [dissertação]. São Paulo (SP): Escola de Enfermagem da USP; 2002.

Krasilchick M. Interdisciplinaridade: problemas e perspectivas. Rev USP 1998; (39):38-43.

Leite MMJ. Tecnologias educacionais: possibilidades e dificuldades limites no ensino de Administração de Enfermagem [tese livredocência]. São Paulo (SP): Escola de Enfermagem da USP; 2000. 
Leopardi MT. Metodologia de pesquisa na saúde. Santa Maria: Palotti; 2001

Libâneo JC. Adeus professor, adeus professora? São Paulo: Cortez; 1998.

Lima E, Maragon C. Os novos pensadores da educação. Rev Nova Escola 2002; (154):154.

Lopes AO. Repensando a didática. São Paulo: Papirus; 1991.

Macedo L. Ensinar: agir na urgência, decidir na incerteza, de Philippe Perrenoud. Rev Pátio Aqui se Aprende [periódico online] 2001; 5(18). Disponível em www.artmed.com.br. (4 ago. 2002).

Magalhães LMT. O ensino superior em Enfermagem e o desafio da mudança: referenciais de um novo processo de formação [tese]. São Paulo (SP): Escola de Enfermagem da USP; 2000.

Martins V. Decálogo do bom professor. [online]. Disponível em: www. psicopedagogia.com.br/artigos. (13 maio 2003).

Masetto MT. Competência pedagógica do professor universitário. São Paulo: Summus; 2003.

Merighi MA. Enfermeiras obstétricas egressas da Escola de Enfermagem da Universidade de São Paulo: caracterização e trajetória profissional. [livre-docência\} São Paulo (SP): Escola de Enfermagem da USP; 2000.

Merighi MAB, Hamano L, Cavalcante LG. O exame preventivo do câncer cérvico-uterino: conhecimento e significado para as funcionárias de uma escola de enfermagem de uma instituição pública. Rev Esc Enferm USP 2002; 36(3):289-96.

Ministério da Educação. Conselho Nacional de Educação. Parecer n.CNE/CES 1.133/2001. Diretrizes Curriculares Nacionais dos 
Cursos de Graduação em Enfermagem, Medicina e Nutrição. Diário Oficial da União, Brasília, 03 out. 2001. Seção 1 E, p. 131.

Moran JM. Ensino e aprendizagem inovadores com tecnologia. [online]. Disponível em: www.educacional.com.br/reportagens. (02 jun. 2002).

Morin E. Tofler e Morin debatem sociedade pós-industrial. In: Pimenta SG, organizador. Saberes pedagógicos e atividade docente. São Paulo: Cortez; 1999.

Nimtz MA. O significado de competência para o docente de Administração em Enfermagem [tese]. São Paulo (SP): Escola de Enfermagem da USP; 2003.

Niskier A. A educação no século XXI. Rev Cultura IMAE, São Paulo, $2001 ; 2(3): 15-7$.

Nóvoa A. Os professores na virada do milênio: do excesso dos discursos à pobreza das práticas. Educ Pesq 1999; 25(1):11-20.

Ohl RIB. Compreendendo a competência interpessoal na vivência do ser-docente no contexto relacional com o aluno de Graduação [tese]. São Paulo (SP): Escola de Enfermagem da USP; 2002.

Peres HHC. A percepção dos docentes universitários `a respeito da sua capacitação para o ensino de enfermagem. Rev Esc Enferm USP 1998; 32(1):52-8.

Peres HHC. O ser docente de Enfermagem frente ao mundo da informática: um olhar na perspectiva da Fenomenologia Social [tese]. São Paulo (SP): Escola de Enfermagem da USP; 2001.

Perrenoud P. Dez novas competências para ensinar. Porto Alegre: Artes Médicas; 1999.

Perrenoud P. Dez novas competências para ensinar. Porto Alegre: Artes Médicas; 2000. 
Perrenoud P. Ensinar: agir na urgência, decidir na incerteza. Porto Alegre: Artmed; 2001.

Perrenoud $P$. As competências para ensinar no século XXI: a formação dos professores e o desafio da avaliação. Porto Alegre: Artmed; 2002.

Pimenta SG. Formação de professores: identidade e saberes da docência. In: Pimenta SG organizador. Saberes pedagógicos e atividade docente. São Paulo: Cortez; 1999.

Pimenta SG, Anastasiou LGC. Docência no ensino superior. São Paulo: Cortez; 2002.

Prado C Ensino-aprendizagem da Escala de Coma de Glasgow análise de duas técnicas em enfermeiros do serviço de emergência. São Paulo, 2001. 108 p. Dissertação (Mestrado) - Escola de Enfermagem, Universidade de São Paulo.

Prado C, Bento MRA, Rodrigues JM, Lacerda KC. A sala de aula de um novo tempo. [Iniciação Científica]. São Paulo, Curso de Graduação em Enfermagem; UniFMU; 2002.

Prado C, Bitencourt SC, Ferreira MCV, Jesus MB. Identificando o ambiente de ensino vivenciado por alunos de um curso de graduação em Enfermagem. [Iniciação Científica]. São Paulo, Curso de Graduação em Enfermagem; UniFMU; 2003.

Prado C, Fonseca AL, Sodré RS. Identificando o conhecimento do graduando de enfermagem sobre a comunicação não-verbal. [Monografia - Trabalho de Conclusão de Curso]. São Paulo, Curso de Graduação em Enfermagem; UniFMU; 2003.

Prado C, Patrício AC, Pita RC. Identificando a fonte e a clareza das orientações dadas aos idosos sobre medicações. [Monografia Trabalho de Conclusão de Curso]. São Paulo, Curso de Graduação em Enfermagem; UniFMU; 2003.

Prado C, Bitencourt SC; Souza JF, Pieroni SRM. Identificando as estratégias de ensino utilizadas por docentes de um Curso de 
Graduação em Enfermagem. [Monografia - Trabalho de Conclusão de Curso]. São Paulo, Curso de Graduação em Enfermagem; UniFMU; 2004.

Prado C, Ferreira EM, França L, Barbieri JA. A opinião dos graduandos de enfermagem sobre a indisciplina na sala de aula. [Iniciação Científica]. São Paulo, Curso de Graduação em Enfermagem; UniFMU; 2004.

Pinto EMB. Educação dentro de uma visão holística. [online]. Disponível em: www.psicopedagogia.com.br. (02 jun. 2002).

Ramos C. Sala de aula de qualidade total. Rio de Janeiro: Qualitymark; 1997.

Rios T. As dimensões da competência do educador. In: Rio T, organizador. Ética e competência. São Paulo: Cortez; 2001.p.4568.

Rios T. Dimensões da competência. In: Rios $T$, organizador. Compreender e ensinar. São Paulo: Cortez; 2002. p.93-100

Rocha EM. Comportamento comunicativo do docente de enfermagem e sua influência na aprendizagem do educando [dissertação]. São Paulo (SP): Escola de Enfermagem da USP; 1999.

Santos GE. Compreendendo as expectativas em um Curso de Graduação em Enfermagem: o olhar discente e docente [tese]. São Paulo (SP): Escola de Enfermagem da USP; 2005.

Schutz A. El problema de la realidad social. Buenos Aires: Amorrortu; 1974.

Silva EA. A meta é a qualidade. Rev Cultura IMAE $2000 ; 1(1): 46-8$.

Silva MG. Comportamento docente no ensino de graduação em enfermagem: a percepção dos alunos [dissertação]. Ribeirão Preto (SP): Escola de Enfermagem de Ribeirão Preto/USP; 1997. 
Soares MAL. Compreendendo a ação do docente no processo educacional de um curso de graduação em enfermagem: o olhar dos sujeitos envolvidos [tese]. São Paulo (SP): Escola de Enfermagem da USP; 2004.

Souza PR. O papel da educação na formação profissional. Rev Cultura IMAE, São Paulo, 2001; 2(3):11-4.

Spíndola T. A fenomenologia e a enfermagem: algumas reflexões. Rev Esc Enferm USP 1997; 31(3):403-9.

Vasconcellos CS. Coordenação do trabalho pedagógico: do projeto político-pedagógico ao cotidiano da sala de aula. São Paulo: Libertad; 2002.

Waldow VR. Educação para o cuidado. Rev Gaúcha Enferm 1993; $14(2): 108-12$. 


\section{ANEXO 1}

\section{ESQUEMA DA FENOMENOLOGIA DE ALFRED SCHÜTZ}

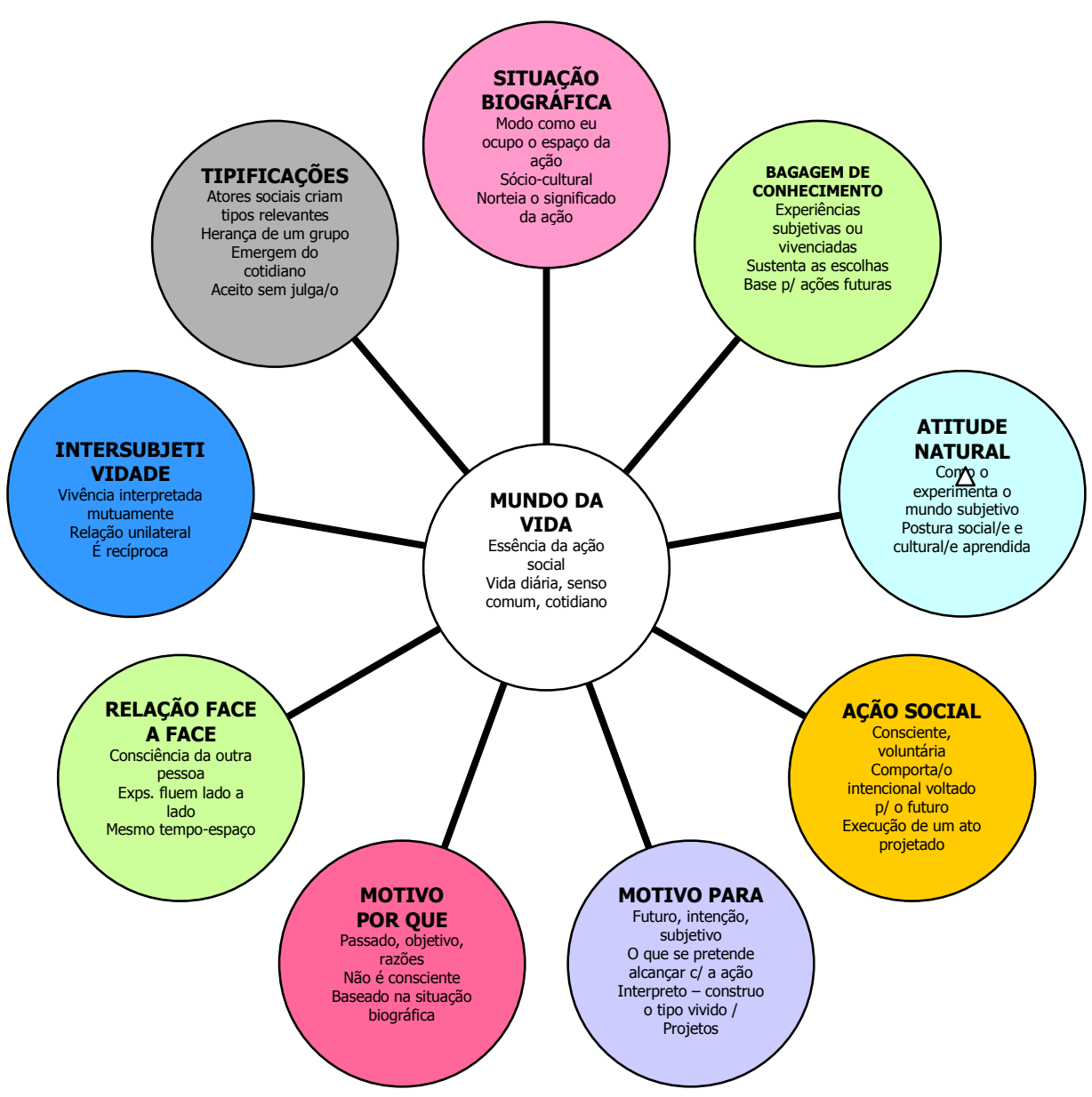




\section{ANEXO 2}

\section{CARTA DE SOLICITAÇÃO DE COLETA DE DADOS}

São Paulo, 01 de setembro de 2004.

Ao Sub-Comitê de Ética em Pesquisa do Curso de Graduação em Enfermagem do

À Ilma. Profa. Dra

Coordenadora do Curso de Graduação em Enfermagem do

Eu, Cláudia Prado, aluna do Programa de Doutorado da Escola de Enfermagem da Universidade de São Paulo, juntamente com minha orientadora, professora Dra. Maria Madalena Januário Leite, estou desenvolvendo uma pesquisa cujo título é "COMPREENDENDO A PRÁTICA DOCENTE EM UM CURSO DE GRADUAÇÃO EM ENFERMAGEM".

Assim, vimos por meio desta solicitar a V.Sa. a permissão para que a coleta de dados para este trabalho, seja realizada, por meio de entrevista, com os docentes deste Curso de Graduação em Enfermagem.

Gostaríamos de ressaltar que será garantido o comprometimento dos preceitos éticos, assegurando o anonimato dos indivíduos participantes e, os dados obtidos serão utilizados 
exclusivamente para se alcançar os objetivos propostos para esta investigação científica.

O projeto segue em anexo e, caso julgue necessário, estamos à disposição para eventuais esclarecimentos no tel: 36615901, cel: 8165-0330 ou pelo e-mail: zeclau@terra.com.br.

Certo de contar com a sua valiosa colaboração, atenciosamente,

Profa. Dra. Maria Madalena Januário Leite

Cláudia Prado

COREN 39649 - SP 


\section{ANEXO 3 \\ TERMO DE CONSENTIMENTO LIVRE E ESCLARECIDO}

Prezado(a) docente,

Eu, Cláudia Prado, aluna do Programa de Pósgraduação em Enfermagem - nível Doutorado, da Escola de Enfermagem da USP quero agradecer a sua participação na pesquisa que estamos desenvolvendo. Esta, tem como título "COMPREENDENDO A PRÁTICA DOCENTE EM UM CURSO DE GRADUAÇÃO EM ENFERMAGEM".e como orientadora Profa. Dra. Maria Madalena Januário Leite.

No presente estudo, estaremos buscando qual a percepção dos docentes de um Curso de Graduação em Enfermagem em relação à sua prática docente.

A coleta de dados será feita por meio de uma entrevista, gravada em fita cassete pela própria pesquisadora, respeitando a disponibilidade e o interesse dos participantes.

A sua participação neste estudo é voluntária e, a qualquer momento, você pode deixar de participar, sem riscos ou prejuízos. Os depoimentos serão sigilosos, portanto, sua identidade não será revelada em nenhuma circunstância. Esses dados serão utilizados, somente, para esta pesquisa e serão divulgados em eventos e publicados em periódicos.

Caso sinta desejo ou necessidade de contatar a pesquisadora em qualquer momento da pesquisa poderá fazê-lo 
pelos telefones $3661-5901,8165-0330$ ou por e-mail zeclau@terra.com.br.

Acreditando que o aprimoramento dos profissionais de enfermagem é uma das chaves mestras para engrandecer esta profissão, agradecemos sua participação.

\section{Consentimento pós esclarecido}

Declaro que, após esclarecimento sobre a pesquisa e, tendo entendido tudo o que devo fazer para participar, consinto em fornecer todas as respostas necessárias para se alcançar os resultados pretendidos nesta investigação.

São Paulo, de outubro de 2004.

Nome do sujeito da pesquisa

Assinatura do sujeito da pesquisa

Cláudia Prado (pesquisadora)

Assinatura da pesquisadora

RG 13.161.590-7

COREN - SP 39649 


\title{
ANEXO 4 \\ ENTREVISTAS COM OS DOCENTES \\ ENTREVISTA 1 - ACEROLA
}

\section{Como tem sido suas ações docentes neste curso}

\section{de enfermagem?}

\begin{abstract}
A disciplina que a gente ministra é focada para as necessidades básicas

enfermeiro. Então a gente foca o curso todo sempre tentando fazer

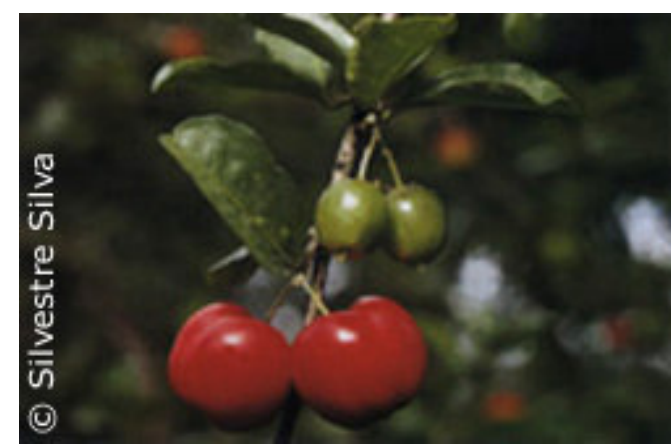

um conjunto com as disciplinas clínicas, semiologia por exemplo, aonde busque as necessidades das disciplinas básicas da anatomia. Então a gente tem sempre em mente esse enfoque: trabalhar as informações da anatomia que vão ser usadas pelo enfermeiro lá na frente, durante a carreira e durante a época dele como docente do curso de enfermagem. A gente trabalha com a parte teórica e a parte prática. Na parte prática a gente orienta os alunos ou através de mesas demonstrativas, ou através de estudo livre na prática mas sempre com um roteiro de estruturas anatômicas que ele tem
\end{abstract}


que conhecer, que são as mais necessárias para ele e em cima disso também a gente trabalha toda a parte teórica dando embasamento para eles, além daquelas partes que ele vai ter necessidade como conhecimento geral sobre o corpo humano, todas as informações anatômicas do funcionamento do corpo humano. Bom, basicamente a gente trabalha nas atividades práticas, a gente tenta sempre manter entre os alunos um instinto de cooperação para que eles trabalhem em equipe. Então de forma que a gente coloca o conteúdo e faz com que eles rodem nas bancadas sempre em grupos diferentes, para eles estarem sempre trocando opiniões, trocando informações, para facilitar a integração porque a gente acredita que nesse campo ele vai trabalhar sempre dentro de uma equipe e a troca de informações vai ser muito importante. Então a gente já procura desde o primeiro ano a ter, a orientar isso, né, a trocar conhecimento, conhecimento clínico, e isso a gente abre também nas aulas teóricas. Então durante as aulas teóricas a gente sempre instiga À perguntas, assim: Alguém já viu isso na clínica ? O que vocês tem de conhecimento disso na prática ? no dia-a-adia, vocês como técnicos ou auxiliares de enfermagem ... Então a gente procura jogar sempre com essa curiosidade deles e a relação com o que lês vêem na prática e o trabalho da faculdade que é um trabalho muito mais acadêmico. A gente desenvolve os projetos de aulas teóricas, projetos de 
Monitoria onde os alunos são previamente selecionados, e passam a acompanhar visando mais a formação da própria disciplina, no caso da monitoria, e nas Iniciações Científicas visando mostrar para o aluno as formas de pesquisa existentes, como é que eles vão trabalhar para tentar orientá-los no sentido de trabalhos científicos mesmo, pesquisa.

\section{O que você espera agindo desta forma?}

O que a gente espera, primeiramente, é que ele tenha um domínio bastante grande da parte de anatomia que ele vai usar para a clínica e além disso trabalhar na base desse aluno, instigando a pesquisa científica, instigando a curiosidade científica, o conhecimento e o relacionamento. A gente procura muito trabalhar com isso demonstrando para eles que a área de saúde é uma área fundamental para você ter respeito, onde você tem que ter solidariedade, então a gente procura trabalhar muito esses conceitos, dentro e fora da disciplina extrapolando coisas da disciplina um pouquinho.

Eu como professor de disciplina básica, o que eu acho fundamental é que você saiba elaborar uma disciplina voltada para cada curso que você dá. A gente que trabalha em disciplina básica tem a oportunidade de trabalhar em várias escolas. Então você dá aula para vários cursos e eu vejo algumas vezes que as 
disciplinas básicas tem sempre um mesmo caminho. Eu acho que não é bem por aí. Você tem que focar o seu curso nas necessidades de cada um. Então, aqui por exemplo a gente tem uma metodologia de um curso voltado para a área de enfermagem. Se pegar uma outra área como odontologia, é completamente diferente, um perfil diferente. Eu acho que as disciplinas básicas tem que ter muito esse cuidado. Identificar isso não é sempre que a gente vê, né ? mas eu acho isso fundamental para toda disciplina básica: é focar o curso na necessidade futura de cada curso. 


\section{ENTREVISTA 2 - JAMBO}

\section{Como tem sido suas ações docentes neste curso}

\section{de enfermagem?}

$$
\text { É, eu diria que as }
$$

minhas ações docentes eu acho que muitas vezes elas acabam não se dando exatamente da forma que eu idealizo o docente, pela própria

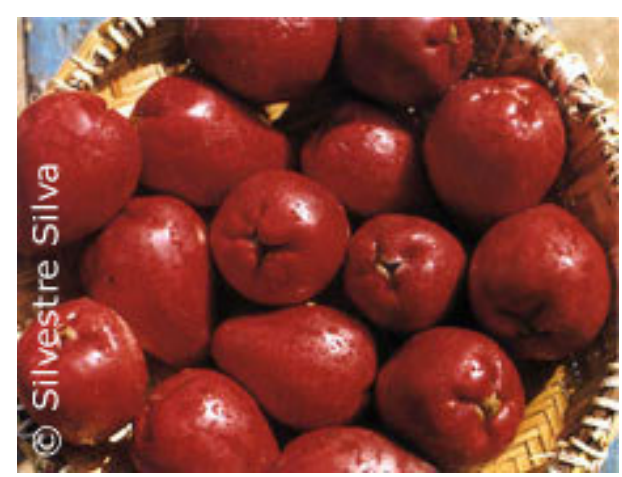
estrutura do curso, né? É um curso ... que você ... trabalha com produção, né? é assim que eu sinto o curso e muitas vezes eu me sinto frustrado em relação a isso, né? Porque você tem que cumprir carga, né então a carga horária, você tem que cumprir programa, né você não tem uma flexibilidade de mexer muito nesse programa de acordo com o desenvolvimento da turma, né? Porque eu tenho uma experiência docente já anterior, e nessa experiência docente, é ... era muito diferente porque eu entendo a docência, né de uma forma assim: você caminha de acordo com os passos da turma, tentando fazer com que essa turma caminhe, e aqui independente dos passos, você tem que puxar esse aluno para que ele caminhe nesses passos, que é um passo já determinado, é um programa para cumprir e esse programa tem que ser cumprido, né ? Então, 
eu sinto uma dificuldade de trabalhar nesse sentido. Procuro fazer o melhor possível, lógico né ? mas eu tenho dificuldade porque assim você não tem essa possibilidade, a flexibilidade de mexer nessas questões de poder trabalhar de uma forma mais flexível né, então é ... Às vezes eu me sinto um pouco frustrado nesse sentido. Então, assim, é ... como é que tem sido né, acho que é assim as minhas ações docentes, eu tenho procurado fazer o melhor possível, né? Aqui eu faço uma coisa que eu nunca tinha feito antes e que eu não gostava, né, que é justamente trabalhar com aulas preparadas por outros professores. Eu entendo assim, o docente tem que preparar a sua aula para poder trabalhar, né. É aqui, não aqui você tem seguir um padrão, que todo mundo tem que ouvir a mesma palavra. Então se todo mundo tem que ouvir a mesma palavra, um prepara a aula e todos dão aquela mesma aula com todas as palavras. No início foi muito ruim né, eu me sentia andando com as pernas alheias, tá certo? E esse andar com as pernas alheias muitas vezes você tropeça, né então essa questão, foi uma questão de difícil adaptação. Hoje eu encaro com uma naturalidade maior até porque assim, eu dependo do emprego e tenho que me encaixar na realidade que eu estou inserido, né? Mas se você me perguntar se é uma coisa que me agrada, não me agrada, né e se eu pudesse mudar isso eu mudaria. Então, esse trabalho né, na produção, em ritmo de produção, eu acho que é 
ruim principalmente na graduação. Porque quando você buscar formar o profissional, né você precisa ter uma flexibilidade maior, essa possibilidade de trabalhar as dificuldades que vão surgindo e eu acho que algumas vezes você acaba ficando meio negligenciado, né justamente porque você trabalha nesse toque de caixa e você não tem essas possibilidades, né? Eu vejo assim, eu procuro fazer o melhor possível, procuro sempre acertar da melhor forma mas ainda entendo que muitas coisas acabam ficando pendentes nesse processo todo. O meu dia-a-dia é assim, eu dou aula alguns horários da manhã, alguns horários da tarde, trabalho muitas disciplinas, né eu trabalho Bases teóricas e instrumentais em 3 turmas, trabalho Semiologia III em uma turma e trabalho Saúde do Idoso I em uma outra turma, trabalhei Saúde do Idos II em duas turmas no início do outro semestre e trabalho as disciplinas de Dependências (DP) Semiologia I, II, III e Saúde do Idoso I. Então assim, por isso eu digo, é um ritmo de produção, eu não tenho tempo para pensar. Eu tenho que simplesmente usar o material do meu colega que já tá pronto, né, tenho procurado preparar minhas aulas de Saúde do Idoso porque é uma área que eu gosto de estudar, né e que eu gosto de trabalhar então eu acabei mexendo um pouco no programa e estou tendo que preparar muitas aulas, né? Preparo isso no final de semana, então meu final de semana é para preparar as aulas para Saúde do Idoso 
para eu poder trabalhar na semana, né? E então assim, é um ritmo de muita loucura, eu não tenho muito tempo para pensar, é ... em como está acontecendo esse processo todo. Eu só tenho que dar conta do processo. Então assim hoje, por exemplo, a minha situação é assim: eu estou dando conta ? Não, não estou ! Eu tenho muitas provas pendentes para corrigir, né que eu não consegui dar conta de corrigir as provas justamente por causa desse toque de caixa que a gente trabalha. Muitas disciplinas para você conseguir ter uma carga horária é ... compatível, para você ter um salário melhor, porque você é horista. Isso me gera uma sensação às vezes de desconforto, de opressão, né, às vezes um sentimento meio de culpa, porque você deixa pendente algumas cosias, né? e assim, insatisfação com o trabalho porque o trabalho tem que te dar prazer, até porque eu faço o que gosto, né e se eu faço o que gosto ele tem que me dar prazer e muitas vezes eu não sinto isso prazeroso. Então assim, não sinto prazeroso por conta dessas pendências, desse ritmo. O contato com o aluno para mim é muito prazeroso, né isso me faz bem, isso me deixa contente. Hoje, por exemplo, eu fui substituir um professor no laboratório, que estão em licença médica, dei lá 3 horas de aula no laboratório, na substituição. Foi assim ... foi muito gostoso, foi uma atividade gostosa com o aluno, alunos que eu não conhecia, né a gente consegui fazer um trabalho legal. Então, isso é prazeroso, mas o 
ritmo que se trabalha não é prazeroso. Aí tem orientações do Trabalho de Conclusão de Curso (TCC), que é uma cosia assim: na minha opinião eu gosto de trabalhar a orientação. Então assim, eu me sinto bem trabalhando na orientação. É ... não gosto muito do ritmo em que se trabalha a orientação aqui, né porque você não tem opção de escolher o tema, você trabalha qualquer tema, o tema é imposto. Então, como você não tem opção, você é obrigado a orientar aquilo que vem para você. Eu procuro fazer o melhor possível, dentro da minha capacidade, né mas acho que poderia ser mais prazeroso assim: você ter a oportunidade de escolher o seu tema, de afinidade né ou que os temas fossem distribuídos, pelo menos, pela afinidade né, então olha, trabalho de Saúde do Idoso então se aqui tem de idoso ... trabalhar mais pela linha de pesquisa, que isso não existe. Então você constrói sua linha de pesquisa também né, porque a hora que você orienta uma cosia, orienta outra, nada a ver um com o outro, você não consegue seguir a sua linha de pesquisa, né porque não deixa de ser pesquisa, orientação é a pesquisa também. Então, assim, isso também não é prazeroso. Assim, o trabalho concluído acaba sendo prazeroso porque você viu que você deu conta de fazer, né mas você vive momentos de angústia por conta disso, né. E aí uma outra situação, essa situação, essa situação eu vivenciei no primeiro semestre que eu entrei aqui, né e vivenciei agora 
também. Você, quando vira o semestre, quando você entra no segundo semestre você uma nova orientação, né do jeito que ela vem e você é responsável porque você passa a ser o orientador daquele trabalho. Então assim isso te coloca numa situação bastante delicada porque se o seu colega que orientava está na instituição ainda e você muda muito dependendo da condução que ele vinha dando, você não consegue acompanhar a linha de raciocínio porque você não pensou o trabalho com eles, né. Então você acaba mudando e isso te coloca numa situação delicada perante o outro colega porque ele te pergunta como é que tá indo e assim você vai dizer o que para ele? Olha, mudei, não mudei, o quanto mudei, achei que a sua linha não era muito legal, mudei. Você fica meio sem sabe como responder para o colega. Quando o colega sai, você se sente um pouco mais confortável nesse sentido porque ele já não está mais para te perguntar mas é desconfortável porque você tem que entender o que o colega tinha pensado porque afinal de contas os alunos para tentar encaixar estão aí, né e você tem que continuar um trabalho e assumir aquilo como seu. Então você adota uma criança sem saber se vai criar um marginal ou se você vai criar alguém que realmente vai ser uma pessoa decente. Então dar TCC no segundo semestre é isso que acontece. É como adotar uma criança que você não sabe o que vai dar depois, né. A questão da orientação do TCC, por exemplo, 
grupos muito grandes né, eu oriento um grupo com 5 alunos, é complicadíssimo, né você trabalhar grupos muito grandes de orientação de TCC porque a orientação individual já é um problema. Com 5, pior, muito mais difícil, né. Então assim, são basicamente essas atividades que eu desenvolvo, né. Fora isso, assim, algum outro trabalho de pesquisa porque eu acho que é assim, enquanto docente eu tenho essa obrigação, né. Esse semestre eu concluí um trabalho de pesquisa que a gente estava fazendo em relação a uma atividade né, que era um compromisso que eu tinha aqui da escola. E aí, assim, eu tenho outro em vista tenho outros temas em vista que eu gostaria de estudar, de pesquisar, de escrever a respeito e na verdade, nessa roda viva eu não consigo, né porque você não tem tempo hábil para nada, né ? O pouco tempo que sobra você tem família ainda (risos ...), você também tem família e precisa também estar um pouco ainda com a família. Por isso você não para pra pensar em você. Você para pra pensar em você, né aí você vai ver que não dá tempo de pensar em você, na família e no seu trabalho. Então você prioriza o trabalho, porque é dele que você depende e a família porque afinal de contas não dá para você abandonar. E em você, quando der você lembra e faz alguma coisa por você pessoalmente. 


\section{O que você espera agindo desta forma ?}

É, na verdade, assim, eu faço muitas ações desse jeito porque é a condição que eu tenho de trabalho, né ? Mas como eu já disse eu procuro fazer o melhor, eu procuro fazer o melhor justamente é ... porque ... eu entendo que eu tenho uma responsabilidade grande na formação do meu colega enfermeiro. Enquanto educador, porque assim, antes de mais nada eu me vejo como um educador, e como educador eu tenho essa responsabilidade: de mostrar para essse meu educando, né que ele tem um compromisso social, né ... sendo enfermeiro, né. Então eu acho que assim eu acabo vivendo um pouco essa roda viva justamente por conta disso. Porque eu entendo que eu tenho essa responsabilidade muito grande com esse indivíduo, na formação desse indivíduo até porque nossa clientela ela tem uma característica diferente de outras universidades, né ? Esse aluno que já vem com uma formação prévia, uma prática anterior em enfermagem como auxiliar ou como técnico e eu não posso ignorar que ele tem um conhecimento, né ? Que se eu ignoro que ele já trás um conhecimento eu deixo de ser educador. Então assim, é justamente com essa visão de educador, de que esse indivíduo que vem para mim, né, ele vem com uma prática e um conhecimento que eu tenho que aproveitar esa prática e esse conhecimento, 
fazer com que ele perceba, né o que ele conhece, quais são as deficiências que ele tem nessa formação de base para eu poder trabalhar então em cima dessas deficiências e no final de tudo, né, o produto é eu ter um enfermeiro com qualidade de enfermeiro, com formação compatível com a de um enfermeiro, com a capacidade de pensar como enfermeiro, capacidade de agir como enfermeiro, né ? Eu vejo que isso é muito mais difícil quando você já tem um profissional que já tem uma prática prévia do que quando você tem um aluno que não tem experiência nenhuma na área de enfermagem, né e você forma ele com essa visão. Agora quem já trás uma experiência anterior ele tem parâmetros de julgamento, né. Então assim, aí esses parâmetros acabam aparecendo durante as aulas, né. E o meu parâmetro para ele é assim: e você nesse processo, como é que é isso ? Porque se eu quero levar esse indivíduo a pensar a respeito, eu tenho que botar ele nesse processo todo para ele pensar. Então é um trabalho assim, de reflexão junto com esse aluno trazendo à tona essas dificuldades que ele vive, inclusive tentando colocar isso junto com os conteúdos que a gente aborda na sala de aula para que eu consiga realmente chegar no que eu entendo que é o ideal: é você ter um enfermeiro capaz de pensar, alguém que seja crítico, que seja reflexivo, e criticar não é falar mal, criticar é você ser capaz de perceber e de dar soluções para os problemas, né. É ser capaz de 
enxergar além, que eu entendo que isso é fundamental para o enfermeiro, né, enxergar além e enxergando além ele vai ser capaz de resolver problemas, né e prevenir problemas de qualquer ordem administrativa, ordem técnica ou assistencial, né, essa é a minha intenção. Eu entendo que o aluno tem que chegar nesse momento, né ... e talvez existam caminhos menos árduos do que esse que eu vivo mas por enquanto, assim o que eu consigo fazer é justamente isso, né, é num caminho muito árduo e acho que é assim até por conta de uma sobrecarga de turmas que eu trabalho para poder manter, que é a questão salarial, que envolve tudo isso.

Não sei se eu queria falar mais alguma coisa, eu só diria que assim, é ... para ser docente ou você gosta exatamente de ser docente ou você não consegue ser docente. Ser docente é isso, é você viver esses momentos que muitas vezes te trazem muita angústia mas À partir disso aí é você fazer o melhor possível, né, porque você forma outros profissionais e se você forma outros profissionais eles são seus colegas e futuramente vão estar assumindo o seu lugar porque eu não posso esquecer que daqui a algum tempo eu estou fora do mercado de trabalho porque eu me aposento e eles vão entrar no meu lugar como docentes, como enfermeiros e assim é .. eu dei o melhor eu quero que alguém continue dando o melhor nessa formação. Então eu tenho que formar o melhor profissional, para que ele seja o melhor para 
poder assumir tudo isso no meu lugar. Se você me perguntar se eu sou bom no que faço eu te digo claramente, sem o mínimo constrangimento, que sou, tá ? Não tenho vergonha nenhuma de dizer isso mas também não tenho vergonha de te dizer assim: sei que existe gente muito melhor que eu, né, mas eu sou bom no que faço. 


\title{
ENTREVISTA 3 - PITANGA
}

\section{Como tem sido suas ações docentes neste curso}

\section{de enfermagem?}

\begin{abstract}
Bom, eu sou professora
de uma disciplina conhecida como

$\mathrm{CHE}$, que é Citologia, Histologia e

Embriologia durante a maior parte do
\end{abstract} tempo. Agora com a mudança de

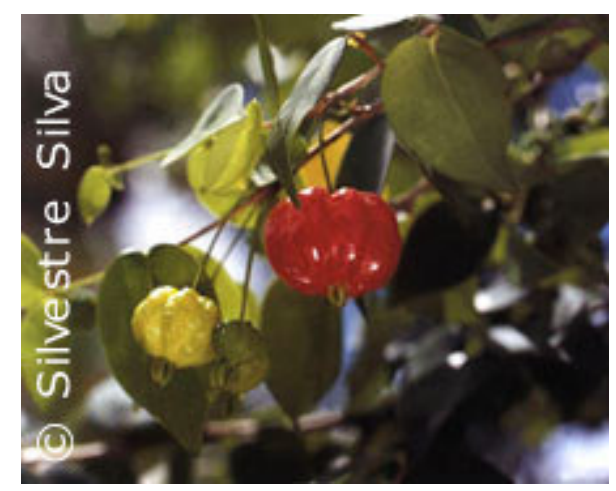
currículo se tornou só Citologia e Histologia e uma outra que agora é Embriologia e Genética, anteriormente só Genética. É ... sou docente orientadora de trabalhos de Iniciação Científica e de trabalhos de conclusão de curso. Qual é a minha ação dentro da sala de aula ? A minha ação dentro da sala de aula é ... eu digo que ela é tradicional no sentido de utilização de estratégias, a maior parte do tempo eu trabalho com aula expositiva dialogada, é ... por algumas razões: uma delas é características das próprias disciplinas que eu ministro, são disciplinas complexas, os alunos são primeiro anistas, muitas vezes do primeiro semestre, é uma quantidade de assuntos grande, muita informação e ... eu embora tenha toda essa questão de não ser conteudista, eu ainda acho que a gente tem também que ter o pé no chão e saber que se esse 
aluno ficar faltando muita coisa para ele, ele vai sair daqui muitas vezes sem saber o que ele vai encontrar por aí e... então pela característica da disciplina, pela estrutura da sala de aula e pelo número de alunos. Então tudo isso acaba contribuindo para que a aula seja uma aula expositiva, enfim. A maior parte das vezes eu utilizo como recursos a lousa, o giz e o retroprojetor, as vezes data-show que a aula principalmente na Histologia porque eu posso trazer fotos. Utilizo laboratório também, não muito. Gostaria de utilizar mais mas a carga horária ela acaba limitando essa ida ao laboratório porque acaba tomando tempo e ... agora eu tenho mudado um pouco porque eu tenho trabalhado desde o semestre passado com estudos dirigidos, bastante, mas sem dispensar a aula expositiva. As vezes eles fazem o estudo dirigido do assunto que vai ser tratado antes da aula. Então isso possibilita que o aluno durante a aula participe mais. Isso ajuda para mim e acho que ajuda o aluno. Ah ... não trabalho em CHE com seminários, particularmente eu acho que é difícil você conduzir um seminário e ... eu trabalho em genética algumas vezes com discussões porque são assuntos que eles tem, ao longo da disciplina, eles tem mais condições de ler e de discutir mas eu não trabalho com seminários. Eles expõem, mas eles só vão saber quem vai expor no dia. Então todos eles tem que saber o assunto, e isso acaba levando a uma grande discussão mesmo. É ... costuma ser bem interessante. Fora 
de sala de aula eu procuro atender os alunos, sempre que eu sou solicitada, é ... muitas vezes são dúvidas até de assim outras disciplinas ou de professores as mesma disciplina e isso acaba trazendo uma situação um pouco constrangedora mas eu também não costumo negar o auxílio. E ... como professora de IC e TCC eu acho muito interessante mas limita muito o fato da agenda do professor ser diferente da agenda do aluno, os horários são complicados. Mas agora com e-mail e tudo mais eu acho que facilitou bastante e esse ano particularmente essa questão de troca de e-mails está funcionando muito bem, talvez até melhor do que se nós tivéssemos reuniões toda semana porque as vezes isso provoca um problema mesmo, o aluno tem que ficar pedindo folga, enfim ... A gente tem algumas reuniões pontuais, grandes reuniões, as reuniões são longas geralmente, produtivas porque isso já foi trabalhado em cima de leituras. Olha, a prática de orientação é um pouco recente para mim, eu estou no $3^{\circ}$. Ano de orientação. Cada ano vem se tornando mais fácil, é o que se espera. É ... mas tem sido muito gratificante. Esse ano, particularmente, porque modificou-se o critério de seleção com a entrevista, né, tá muito melhor porque o aluno corresponde mais ao que você esperava. 


\section{O que você espera agindo desta forma?}

Bom, é ... eu vou um pouco assim por tópicos. Com relação a quantidade de assuntos abordados, porque isso acaba levando a escolha de estratégias, a minha intenção é, claro a gente não vai conseguir passar tudo para o aluno, mas deixar com que ele conheça o maior número, a maior quantidade de informações possível para ele não ter a situação assim de sair da disciplina ou até de terminar o curso e falar, puxa vida, eu nunca vi isso na minha vida. Ele tem que saber, pelo menos, para onde ele vai correr, para que livro ele tem que consultar, do que se trata. Então essa é a minha intenção em tentar sempre fechar o programa. É ... as novas estratégias de estudo dirigido para que o aluno, a aula, que é uma aula longa, cada encontro são 3 horas/aula, parte desse estudo dirigido eu desenvolvo mesmo em sala de aula para eu não ficar 3 horas/aula sempre só falando em uma única estratégia. É ... então essa é a intenção do estudo dirigido e a outra intenção é que ele tenha um contato prévio ou que ele tenha contato posterior obrigando esse aluno a reler essa matéria até a semana seguinte onde será outro assunto abordado. Então ele vai ter que rever, pelo menos ele vai ter que ver duas vezes antes da prova. Ah, eu acho que é isso ... Bom, no TCC o aluno já vem muito pronto prá gente. Então, ele as vezes já vem com o objetivo dele mas eu, 
como orientadora, eu espero facilitar todo esse processo da pesquisa e da montagem do trabalho e que ... claro isso tem algum significado para ele depois porque o TCC é um pouco um mestrado engatinhando, né, você vai começar a se especializar cada vez mais e vai estudar um grão de areia no meio de uma praia, Agora a IC eu tenho mais ... eu deposito mais expectativa porque você pega uma aluno que muitas vezes não passou ainda por uma disciplina de metodologia científica, então eu espero que ele, ao término da IC, conheça a estrutura de um trabalho científico, e toda vez que ele for pesquisar alguma coisa, quando ele for pesquisar que ele saiba identificar aquelas fases do trabalho científico em tudo que ele for pesquisar. Essa é a intenção. 


\section{ENTREVISTA 4 - CUPUAÇU}

\section{Como tem sido suas ações docentes neste curso}

\section{de enfermagem?}

Obrigada pelo convite. As minhas ações, Cláudia, elas tem sido um pouco mais amplas é ... no decorrer da minha carreira como docente. Nesses últimos 2 anos minhas ações tem sido no primeiro momento informativas. No momento em que eu ministro uma

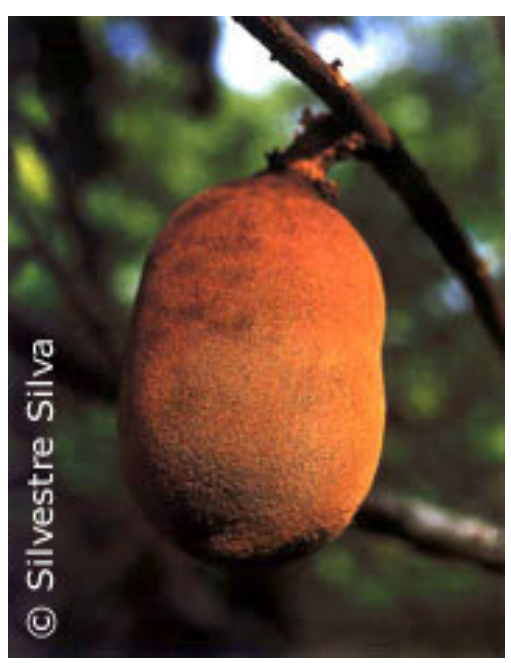
disciplina eu procuro estar inserindo nessa disciplina informações pertinentes a mesma e voltados para a realidade de morbi e mortalidade do Brasil. Então eu tenho uma ação, em primeiro lugar, informativa. Eu acredito também que eu tenha uma cão importante do ponto de vista de formação desse aluno no momento onde eu ensino pra ele noções da formação de um profissional da área de saúde, de um profissional enfermeiro, né ? Tenho também uma ação que eu acredito que seja muito motivadora. Eu motivo eles a estarem pensando nas perspectivas da enfermagem, estarem pensando no seu papel em relação a ... a importância do seu papel dentro da equipe de saúde e uma ação 
reflexiva também, né ? Do quanto nós somos participativos, o quanto nós deixamos de ser participativos, faz com que lês repensem um pouco até por serem profissionais da área de saúde, né, que eles tenham essa ação reflexiva em relação a essa prática, até onde que nós podemos chegar, até onde que nós estamos indo de verdade, né, penso também que eu tenho uma função de articuladora em relação ao futuro desses profissionais, como uma pessoa que já tem quase 20 anos de formada. Sou chefe de duas disciplinas, chefe de uma pós-graduação, então eu acredito que na formação desse nosso aluno, que é um aluno especial em relação a ouras faculdades, porque um aluno com muitas carências, com muitas dificuldades, com muitas ..., já com um passado dentro da área de saúde muito heterogêneo, eu acho que essa articulação em relação ao futuro é muito importante de um professor da área de enfermagem. E tento também abrir perspectivas para esses alunos no sentido de mostrar uma visão atual do panorama do país, das perspectivas que se apresentam dentro da área de enfermagem. Agora, eu acredito que sejam áreas que no futuro aqueles que tiverem motivados em relação a essas áreas poderão ter maiores chances no mercado de trabalho. Então, eu acredito que as minhas ações se resumam e, informativas, formativas, motivadoras, reflexivas, articuladoras e nas perspectivas de um futuro dentro da área de enfermagem. Eu participo de duas disciplinas, dou aula, 
participo junto com os alunos dentro da ..., de atividades fora da sala de aula como orientadora de trabalhos de conclusão de curso, também participei com eles já há uns dois anos como monitora, orientadora de trabalhos extra-classe, relacionados À Semana da Enfermagem, voltados pra área importante de morbi-mortalidade dentro do país e participo junto com eles também de orientações e trabalhos para apresentação em congressos. Então, no meu dia-adia, são essas as atividades básicas que eu desenvolvo junto com esses alunos.

\section{O que você espera agindo desta forma?}

Bom, na verdade, eu tenho, não sei se é a pretensão ou a esperança de contribuir na formação desse aluno, não só do ponto de vista técnico de informações e formação, mas também de tentar contribuir nas minhas aulas, durante as minhas aulas, que são aulas que refletem diretamente alguns problemas de morbimortalidade brasileira, muito fortes atualmente, eu tento sempre trazer nessas minhas aulas além desse aspecto formativo e informativo que o aluno reflita, reflita sobre a nossa prática, que ele reflita sobre as reais necessidades brasileiras, as reais necessidades do nosso país, do nosso povo e que ele compreenda as dimensões reais e futuras como profissional e como cidadão, inserido dentro do contexto brasileiro e do contexto de um 
profissional da área de saúde. É isso que eu espero. Eu espero do fundo do meu coração que eu tenha contribuído nesses anos como docente de alguma forma, estar plantando uma semente intrigante para que esses alunos vão além, que eles vão além da sala de aula, que eles vão além dos livros, que eles consigam ir além do intra-muros da classe, da universidade, e que eles consigam perceber maiores dimensões pro futuro da enfermagem. Isso é realmente o que eu espero. Quero só reforçar a importância desse trabalho que você está desenvolvendo, Cláudia, no sentido de estar mostrando pra gente que no nosso dia a dia isso se perde muito. Estar mostrando um panoramas das perspectivas, das motivações, das nossas ações sendo refletidas nessa população de alunos da Enfermagem. Eu queria te dar os parabéns por isso e acho que esse seu trabalho vai ser muito enriquecedor e vai estar mostrando pra gente no dia a dia nosso que muitas vezes a gente passa despercebido e não consegue enxergar o que nós, como corpo docente e não como indivíduo em separado, como corpo docente, estamos pensando e fazendo por esses alunos, por esses futuros profissionais. Obrigada. 


\title{
ENTREVISTA 5 - AÇAÍ
}

\section{Como tem sido suas ações docentes neste curso}

\section{de enfermagem?}

\begin{abstract}
Tá, então é assim. Eu
iniciei como docente nessa

instituição desde 2001 e aí desde

2001 eu desenvolvo em outra

instituição, eu também ministro a

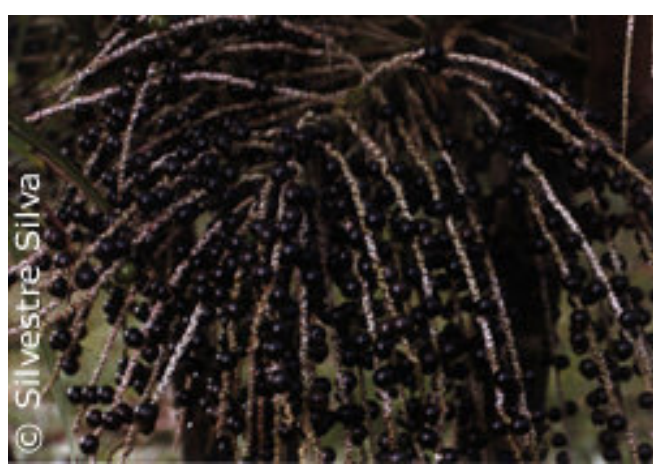

mesma disciplina desde 2000. Então, quando eu entrei aqui eu já tinha um pouquinho de experiência na docência, mas quando eu iniciei na docência eu tinha o conhecimento sobre a disciplina que eu ministro, que é a nutrição para a enfermagem, como eu sou nutricionista, eu tive sempre a preocupação em fazer com que esse ensino para o enfermeiro ele fosse significativo pra ele, e eu sempre tive o cuidado de não colocar questões de ciência da nutrição muito específicas pra ele, porque eu não estava formando, eu não estou formando, auxiliando na formação de nutricionistas, eu sempre tenho que ter isso em mente na minha ação educativa, na minha ação como docente, então. Esse é um ponto básico que para mim, como eu ministro uma disciplina, eu sou outro profissional ministrando uma disciplina então para um futuro
\end{abstract}


enfermeiro aí, contribuindo para a formação do enfermeiro e eu tenho sempre que ter em mente como aquele enfermeiro vai utilizar os conhecimentos da ciência da nutrição, para eu poder direcionar minha ação como docente, então, no desenvolvimento da disciplina. Então aí dessa maneira, como é que eu tento atuar minha ação docente então. Eu tento colocar as questões principais de atuação deles, por exemplo, a nutrição do ambiente hospitalar, onde é que vai então o papel de enfermeiro no cuidado nutricional do paciente hospitalizado e aí eu trago questões pra eles sobre como é a nutrição frente à patologia e aí eu procuro, com estratégia, então de ensino, os estudos de caso, que eu acho que como é uma disciplina teórica, como a minha, ela não envolve a prática, eu acho que dá pra contemplar de alguma maneira através da simulação, como estudo de caso. Então, porque nós temos, então, nutrição I, e nutrição II. Na nutrição II, a abordagem da nutrição frente às patologias, que é chamada então dietaterapia, eu planejo da seguinte forma: eu passo o conteúdo de dietaterapia. Por exemplo: no diabetes. E aí, então, como funciona a nutrição de um paciente que tem diabetes. Aí então eu proponho um estudo de caso em grupo, onde eles vão, eu coloco então várias questões de um paciente e peço para eles colocarem em linhas gerais como deve ser a alimentação desse paciente com diabetes, pra ver se realmente esse conhecimento da aula, se ele está conseguindo 
aplicar esse conhecimento na prática, numa simulação que seria a prática, porque a prática seria a própria prática, uma simulação. Então eu acredito que dessa forma então, é isso que eu tomo como uma ação educativa também, que eu planejo dessa forma assim e em nutrição I, por exemplo, onde eu abordo com eles a questão da nutrição do ciclo vital, aí é um pouquinho diferente, mas também eu procuro puxar pra prática, porque eu acho que é um estudo que fica significativo pro aprendizado do aluno essa questão de você vincular com a prática. Eu acho que hoje não dá mais pra gente abordar conteúdo pros alunos sem vincular com a prática deles, porque eu acho que essa questão hoje está sendo muito exigida pro futuro profissional, é uma necessidade atual. Então, eu procuro também, por exemplo, quando eu abordo a questão de uma criança com aleitamento materno e depois os outros tipos de leite, fórmulas infantis. Então o enfermeiro, quando ele está numa Unidade Básica de Saúde, o que ele deve saber sobre a importância nutricional do leite materno. Então, é isso que eu compenso na disciplina. Então eu coloco um caso de uma mãe que chega na Unidade Básica de Saúde e coloca pro enfermeiro: "olha, eu to dando água pra minha criança além do leite materno porque eu acho que ela tem sede" Aí, o que você faz com essa frase da mãe? Eu pergunto, eu questiono o aluno, porque eu antes passei todo conteúdo do aspecto nutricional do leite materno. Então 
quando eu abordo esse conteúdo com eles e posteriormente eu trago esse caso também, em forma de caso, lógico que eu coloco também a questão do crescimento da criança. Análise de crescimento, mas mais puxando pra nutrição. Então, relacionar a nutrição dessa criança com o crescimento dela. Tá afetando o crescimento? Tá adequado esse crescimento ? O que pode ser de erro alimentar que está afetando esse crescimento etc. O vínculo então da nutrição com o crescimento. E aí então ao perguntar para o aluno questões que ele estaria enfrentando numa consulta de enfermagem numa Unidade Básica de Saúde, eu tenho essa intenção de que ele a partir dos conhecimentos da aula, que ele aplique então no momento que ele está frente à mãe, por exemplo, que ele pode oferecer para essa mãe informações da nutrição, gerais, não tão aprofundadas quanto nutricionistas. Mas ele tem condições e ele está lá no momento de uma consulta de enfermagem, por exemplo, onde as questões da nutrição aparecem. Então, a ação educativa ela fica mais em relação, eu sempre procuro, assim, no início que eu comecei ministrar essa disciplina aqui nessa instituição, eu sempre tenho essa preocupação com o aspecto do significado de enfermeiro. E a partir daí desse objetivo é que eu direciono então as minhas ações. Agora, em relação, por exemplo em relação às estratégias que eu utilizo, eu utilizo sobre textos, procuro relacionar mais artigos 
científicos que trazem mais a questão mais atual do conhecimento. Também tem um artigo que eu trabalho com ele, vários artigos. Agora, no início também da disciplina, com a preocupação desse aspecto do significado que isso tem para o enfermeiro, eu trabalho com um artigo falando realmente do cuidado nutricional, do papel do enfermeiro no cuidado nutricional dos pacientes. E aí nesse artigo trás várias atribuições do enfermeiro frente ao cuidado nutricional do paciente e aí eu espero que com esse artigo eles consigam, consiga ficar mais claro na cabeça deles então o significado da disciplina. Eu dou outra disciplina também e é no $1^{\circ}$ semestre que é Métodos e Técnicas de Estudo e Pesquisa Bibliográfica. E aí nessa disciplina a ação educativa então, em função do objetivo dessa disciplina ela altera um pouco. Então, que contribuição que eu tenho para a formação do enfermeiro nessa disciplina. Ele está no início do curso, então a gente aí já propõe, já divide com outros professores, a gente propõe outras estratégias que venham aí contemplar esse objetivo dessa disciplina que é fornecer subsídios para o aluno se organizar pro estudo, ao longo do curso. Então, por exemplo, nessa disciplina de Métodos, no decorrer da disciplina a gente trata vários conteúdos sobre escrita, sobre trabalho acadêmico, sobre análise de artigo científico, elaboração de texto acadêmico, o que tem uma introdução, o que vale uma introdução no desenvolvimento e conclusão de um 
trabalho e aí, ao final, o critério que a gente tem de avaliação é pra não avaliar só no final, pra avaliar o processo, e hoje também o que está sendo preconizado em termos de avaliação, é você avaliar o processo como um todo e não só ao final de um período. Então a gente no processo chega a avaliar a capacidade de síntese que eles têm ao fazer um resumo. Por exemplo, a gente atribui nota também é uma avaliação - fazer um resumo e depois também fazer a parte de referência bibliográfica. Então há uma avaliação também durante o desenvolvimento e é solicitado um trabalho para o final da disciplina valendo aí a parcial nota também. Faz parte da parcial. Mas nada impede - e eu também aprendi isso no mestrado - no mestrado a gente tem tido contato com essas questões que envolvem a educação no ensino superior, desde a avaliação, as estratégias de ensino, então, como a gente pode aplicar isso. A gente tem visto muita coisa, eu tenho visto muita coisa no mestrado, mas eu noto, Cláudia, que o que eu vejo no mestrado, que tem sido estudado, que tem sido preconizado pro ensino superior, desde estratégias de ensino, avaliação e tal, demora um pouco, a partir do momento em que você entra em contato com essas questões, demora um pouco pra você por em prática isso, na sua atuação docente. Demora até pra você incorporar e a mudança, porque é a ação, a mudança é a ação. Então eu vejo assim, eu vi muita coisa o ano passado e esse ano, 
então eu tento incorporar na minha prática, mas não é automático, porque eu vi no mestrado sobre educação esse ano anterior na área de saúde, né, que eu faço, e com o nosso aluno é a mesma coisa também. A gente não pode esperar que as aulas, que todo o conhecimento, que o resultado seja tão imediato assim. Então é outra coisa que eu estou aprendendo também. Que não é automático. O aprendizado é complexo aí e, da maneira como a gente expõe nas aulas, cada um aprende de uma forma, da sua forma, da sua maneira. Isso que é interessante também. Essa diversidade que ocorre no aprendizado. Por exemplo, eu encontro alunos lá na lanchonete que eu dei aula pra eles, dei a disciplina o semestre passado sobre Métodos e Técnicas de Ensino e Pesquisa Bibliográfica e eles me encontram na lanchonete e falam: "Oi, professora, como são importantes aquelas aulas", porque veja, a aplicação está sendo hoje. Então eu não posso esperar que a aplicação seja tudo naquele momento, mas é posterior, porque tem que ter um tempo de aprendizado também. Mas isso é uma ansiedade para o professor. Eu vejo que às vezes eu me policio também. Mas eu digo "ele não sabe isso, ainda não consegue colocar" - é uma expectativa. Pois é, mas fica, fica presente, ele tem que ter essa noção de que fica presente e ele vai incorporando aos poucos. Aí eu encontro com essa aluna outra vez e ela fala: "Olha, estou usando sua matéria agora para fazer um trabalho do 
professor X". Então, quer dizer, ela está usando o que foi oferecido antes, ela está usando agora, e esse mesmo é o meu intuito. Eu estou envolvida também com o TCC que é um trabalho de conclusão de curso e Iniciação Científica. Esse tipo de atividade é diferente. É bem diferente. E tem algumas peculiaridades bem interessantes. Porque, quando você ministra a disciplina numa sala de aula que tem 50, 60 alunos é diferente. Suas abordagens são com um grupo grande. Agora, o TCC e Iniciação Científica, como são grupos pequenos, de 3, 4 alunos, você tem uma possibilidade maior de rever algumas questões maiores que numa sala de aula de 50 ou 60 alunos você não consegue. Você não consegue, por exemplo, fazer uma avaliação que é aquela que eu acho que seria essencial para você fazer em relação ao aluno, uma avaliação individual. Você tem poucos momentos em que você avalia o aluno individualmente. Aqui na instituição nós temos a prova parcial, que é feita individual e depois a regimental. É nesse momento que você avalia, mas você só avalia conhecimento. Então você avalia hoje em dia. Você só avalia conhecimento, né então pra você avaliar, como hoje em dia é preconizado também, você avaliar habilidades, se você avaliar atitudes né fica a desejar porque você está avaliando ali conhecimento numa prova escrita, né. Então essas questões têm que ser muito aprimoradas em relação a grupos maiores. Agora em relação à IC e TCC, você tem a possibilidade de 
trabalhar ali individualmente com o aluno. Então esclarecer dúvidas de como elaborar um trabalho, né então eu tenho visto que a prática na IC, minha ação docente na IC, e no TCC ela tem sido muito é... prazerosa assim nesse sentido de... você poder verificar qual realmente é a deficiência daquele aluno. Por exemplo: até na parte de digitação do trabalho, né. O aluno tem dificuldade de digitação, por quê? Nós temos hoje muita exclusão digital ainda, poucos alunos nosso têm computadores na sua casa né? Então fica muito a desejar essa questão. Então ele só pode usar aqui na faculdade por exemplo que é um momento que ele pode usar o computador. Então ele não tem tanta habilidade na digitação, em formatação, né, e mesmo assim eu acho essencial na ação docente também você poder direcionar, porque todos os trabalhos que a gente orienta ele tem um corpo, ele tem as normas a serem seguidas, as partes de introdução, tal, tal. Então você situar um aluno, por exemplo, eu tive experiência agora recentemente em um trabalho que eu orientei sobre desmame precoce em lactente, as causas do desmame precoce em lactente. Então nós fizemos só um levantamento bibliográfico. Então delimitamos o tema tal e aí elas trouxeram os artigos científicos que elas encontraram naquele baú de dados e aí as alunas têm dificuldade, que eu acho que é dificuldade do aluno no ensino superior hoje mesmo de entendimento dos textos lidos. Então elas liam, liam, o texto e a 
todo o momento eu falava pra elas: vocês têm que ir na leitura desses textos com esse objetivo principal, que é o objetivo do trabalho, identificar as causas do desmame precoce, buscar na leitura porque eu frisava pra elas... foi duro pra elas chegarem a essa... pois eu acho que faz parte ler??? reler até você incorporar. Então iam para a leitura do texto e aí elas não conseguiam elas traziam desde a introdução do texto, que nós já tínhamos colocado no trabalho também e que não precisava. Então até elas pinçarem o objetivo da leitura foi difícil mesmo trabalhar com esse grupo aí. Então eu acho que mais eu não conseguiria com esse aluno com uma sala com 50, 60 alunos identificar essas questões que também fazem parte do aprendizado na minha ação educativa aí com eles eu não consigo contemplar com uma classe de 50,60 alunos esse tipo de ação assim. Né eu acho que orientador de IC e TCC eu faço a propaganda da IC (risos...) e com esse $1^{\circ}$ semestre aqui porque eu falo pra eles: gente, vão se inscrever na IC por quê ? Porque vocês vão aprender a ler fazer leitura, é mais uma oportunidade, está aqui, é oferecido pela faculdade então vocês têm que aproveitar essa chance aí. Aí eles ficam todos curiosos em saber, mesmo que eles tenham visto aí que é divulgado também no ato da matrícula deve ser, o que a faculdade se propõe durante o curso todo mas eles não têm muita idéia. Então eu esclareço muitas dúvidas e faço já a propaganda no $1^{\circ}$ semestre pra eles poderem 
né, tem hora complementar? Eles ficam perguntando essas questões, como é que é feita a seleção? E tal. Então é bem interessante essa questão. A IC tanto quanto o TCC acho que é importante para o aluno porque ele escolhe o que ele quer estudar mais. Então essa é a grande vantagem, a grande motivação desse aprendizado. Ele escolheu desde o $3^{\circ}$ ano, ele já fez o projeto naquele tema então é que ele tema que ele quer estudar. Então isso já motiva um pouco né mas eles têm dificuldade no andamento do trabalho né por questões, lógico, de ser aluno trabalhador também, então por questões da gente conseguir conciliar horário do professor com o horário do aluno, né. Então mas nessa questão ainda do aprendizado do aluno em relação à ação docente toda, eu tenho aprendido, também pra gente porque aprender a gente não só ensina é uma relação de ensino aprendizagem que a gente chama hoje aí, então nessa relação ensino-aprendizagem. Os autores nem consideram também que existe uma separação né, é a relação ensino-aprendizagem, que não é ensino o tempo todo, a tal aprendizagem também, é a relação ensino-aprendizagem. Então nessa relação eu vejo que por exemplo eu estou também envolvida com a DP, aqui de nutrição, é um outro momento, que são menos alunos na DP aqui de nutrição é outro momento que você tem a oportunidade de trabalhar o aprendizado individual também pelo número menor de alunos. E aí 
eu aprendi também na semana passada com um aluno, comentando sobre o conteúdo da disciplina, então lembra que eu comentei com vocês sobre vitaminas e sobre sais minerais. Aí ele falou assim pra mim o aluno: é professora, da maneira como a senhora colocou na aula eu estudei diferente. Então vejam que com a maneira que o professor apresenta o conteúdo, como ele aborda esse conteúdo com o aluno, nem sempre é a maneira melhor para aquele aluno estudar, daquela forma que foi apresentada. Por exemplo: vitaminas eu apresento funções das vitaminas, fontes, deficiências, tal. E ele aprendeu de maneira diferente. Ele pegou todo o conteúdo e colocou por funções primeiro. Então qual a vitamina que age na cicatrização - quais são ? Têm várias - vitamina $C$, etc... então ele estudou por funções, ele achou melhor aprender por funções. Então, essa é uma dica para eu refletir sobre a minha ação docente também nesse sentido de exposição desse conteúdo para eles. Será que não seria a melhor maneira de colocar vitaminas e minerais, que é um conteúdo aí a ser desenvolvido com eles, de maneira diferente ? É um questionamento. Então a todo momento o aluno também te traz um feed-back, te traz também questões que você pode usar para você melhorar, aprimorar sua docência né e o aluno faz muito isso. 


\section{O que você espera agindo desta forma?}

Eu espero contribuir para a formação do enfermeiro e eu tenho claro que eu contribuo um pouco. Então cada docente aí tem sua contribuição e eu espero que ele vá usar, que ele vá adquirir, construir seu conhecimento, mas não só esse conhecimento construir que ele vá atuar, que ele vá usar esse conhecimento não só então construir pois se ele construir e guardar para ele não serve nada para a prática profissional dele. Então eu espero isso, eu espero... como eu sou nutricionista e estou ministrando uma disciplina para o futuro enfermeiro eu espero também, no decorrer da disciplina, que ele saiba que ele vai trabalhar em equipe multiprofissional, então que ele saiba também que no ambiente de trabalho dele ele vai trabalhar com outros profissionais da área de saúde. Então aí nessa interação nós temos o início de atuação e também temos possibilidades que é todo o trabalho em equipe multiprofissional. Aí vai exigir maturidade, vai exigir uma série de questões ai, e dificuldades que envolve o trabalho da equipe multiprofissional, né mas já a oportunidade que ele tem de verificar outro profissional na graduação, né estar em contato com outro profissional já é um aprendizado de uma equipe multiprofissional. Eu acho que consegui falar tudo, viu? Eu acho assim que a ação docente hoje ela tem muitas dificuldades no 
ensino superior hoje, né. Hoje nós temos a característica de um aluno que chegou até o ensino superior com muita dificuldade também, e ainda uma porcentagem baixa da população brasileira que têm ensino superior, basicamente $9 \%$ da população, de 18 a 24 anos que está no ensino superior. Então eu acho que reflete na ação docente esse perfil de aluno que a gente recebe numa instituição particular de ensino superior. É um aluno que traz dificuldades, né mas ele também traz possibilidades. Então eu acho assim que a ação docente nossa fica entre verificar essas dificuldades, não esquecer essas dificuldades mas verificar possibilidades frente a essas dificuldades. Por exemplo: dificuldade na leitura e escrita, é uma característica do aluno nosso, do perfil de aluno daqui, né mas com essa dificuldade na leitura e escrita o quê que a gente consegue que esse aluno leia um pouco mais? Como é que a gente pode estimular a leitura? Através da sua disciplina e é importante também a ação docente, que eu acho essencial no ensino superior é o intercâmbio entre as disciplinas porque hoje em dia não dá para ficar só a disciplina isolada. A disciplina isolada perde muito e a gente vê que a gente tem a ganhar muito quando a gente faz um intercâmbio com as outras disciplinas, né por exemplo: no início do ano a gente fez uma reunião com outras disciplinas do mesmo período em que por exemplo: a preventiva trabalha questões do ciclo vital também e aí 
a gente procura no mesmo momento eu estar abordando a nutrição no ciclo vital nesses mesmos momentos que a informação preventiva aborda essas questões. Então são momentos em que são essenciais, que haja a integração dessas disciplinas porque só possibilitar que o aluno por si faça essa integração é pouco, né. Eu acho que a gente mesmo, entre os professores tem que haver essa integração aí dessas disciplinas no mínimo nas que ocorrem no mesmo período, no mesmo momento para o aluno, né, mas também tem oportunidade de trazer a contribuição em outra disciplina como convidada, como uma aula específica e tal. Hoje, no ensino superior, o aluno tem essas dificuldades por ser aluno trabalhador que não tem tempo para estudar. Então tem uma série de desculpas que não tem tempo para estudar, mas se ele se dispôs a fazer o ensino superior ele tem que se organizar e ter tempo para estudar senão ele não pode fazer, né, senão não dá para ele fazer. Então assim são questões que tem muita evasão ainda, né do $1^{\circ}$ para o $2^{\circ}$ ano tem uma diminuição de alunos por turma por questões financeiras, né então tem uma série de dificuldades mas eu acho que nossa ação educativa é: frente às dificuldades $o$ que se tem de possibilidades? Porque tem possibilidades de atuação, né. Então é isso! 


\title{
ENTREVISTA 6 - CARAMBOLA
}

\section{Como tem sido suas ações docentes neste curso}

\section{de enfermagem?}

\begin{abstract}
Bom a minha prática tem sofrido modificações desde o momento em que eu entrei aqui. Este é o meu $3^{\circ}$ ano nesta instituição e que eu tive, eu principalmente ter
\end{abstract}

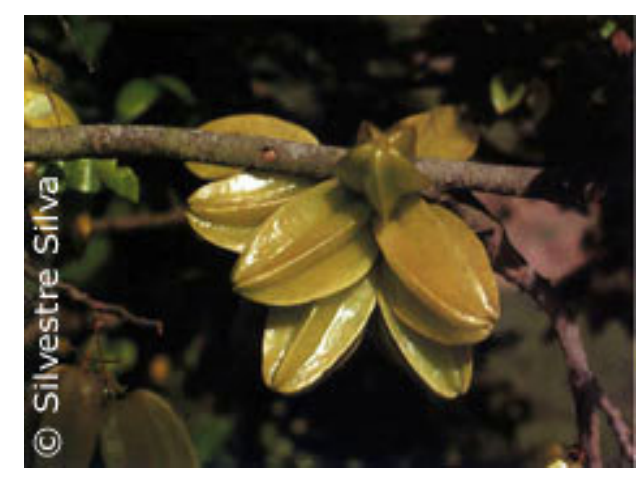
passado por uma adaptação muito grande. Eu vim de um corpo docente de uma outra escola onde o nível, o aluno já ingressava nessa escola muito ... com um padrão de ensino melhor e aqui eu tive que transformar a minha maneira de ver o aluno e de fazer a prática docente, eu tive que transformar essa prática até para chegar ao nível de entendimento desses alunos. Isso para mim não foi fácil, eu acho que eu tive uma série de dificuldades para entender essa diferença de tipo de aluno. No $1^{0}$ momento eu fiquei muito decepcionada porque eu não consigo ver esse aluno que a gente está formando como enfermeiro, ou melhor, eu não vejo esse aluno que a gente forma como a enfermeira que eu sou. Então o que pode ter hoje depois dessas transformações, eu vejo sim, ainda em conflito achando que a formação que a gente dá é 
como se fosse para o nosso aluno ideal e não para o aluno real que a gente têm na sala de aula. Eu me sinto extremamente distante desses alunos em muitos aspectos, eu vejo que muitas coisas que eu falo eles não alcançam, não chega até eles, é... eu acho também que o tipo de enfermeiro que eles têm como parâmetro para se comparar, aquele enfermeiro que está na frente de batalha não é o enfermeiro que está aqui dando aula. Aquele enfermeiro que está na frente de batalha e trabalha junto com eles esses alunos nossos enquanto auxiliares e técnicos é um outro enfermeiro muito mais próximo da realidade do que nós professores somos, eu digo nós, eu. Na minha disciplina eu falo muito de humanidade, né, eu trabalho muito com o aspecto humano da gravidez, parto, da condição de ser mulher, mais filosófica talvez e que não chega ao aluno, ta. Ele tem dificuldade básica de entendimento de uma série de coisas e eu acho que se o aluno conseguir discutir questão de gênero, papel social e tudo mais é ... não é esse aluno nosso aqui que consegue discutir. Aliás eu questiono se existe um aluno (risos...) que consegue discutir isso. Então nesse ponto eu me sinto assim muito frustrada, muito mesmo, né e então assim essa coisa de trazer o tempo inteiro o aluno para uma coisa tão palpável, tão básica em alguns momentos eu falo gente mas né que enfermeiro vai ser este ? Frustra bastante! Mas assim ... eu outro dia falei aqui na sala dos 
professores que eu acho que isso é um sinal de que realmente eu estou assim muito inadaptada ao meio. Eu senti que as vezes precisa entrar um outro enfermeiro enquanto professor para estar aqui na frente, com microfone, falando de coisas mais reais para esses alunos, eu acho assim que esse vai ser o momento que o aluno vai conseguir perceber: bom, essa enfermagem que eu vivo é essa enfermagem que eu estou ouvindo desse professor, então eu aprendo. Mas não com o tipo de enfermeiro como, eu tenho já 20 anos de formada então eu acho que a minha formação foi por outro caminho. 0 que eu busquei nesses 20 anos me levou para uma outra percepção de enfermagem, né então as vezes eu acho que precisaria de um professor até muito mais técnico, muito mais prático, muito mais palpável né do que um professor que ficasse discutindo questões sociais, junto com uma disciplina como saúde da mulher. E frustra por quê ? eu acho que essa disciplina tem tudo a ver com essas questões, né ? Então que tipo de profissional que a gente ta formando? É o que vai lidar com questões palpáveis, concretas, saber orientar o método? Pode ser que sim, pode ser que esse seja o enfermeiro que a nossa população precise, não um enfermeiro que ancore a mulher em questões mais assim profundas e tudo mais. Então eu me vejo às vezes muito inadaptada ao meio em que estou! Bom na parte prática, eu acho que minha ação enquanto docente na clínica ela é um pouco mais 
tranqüila porque eu lido só com o técnico então aí não tem muito stress até pela quantidade de conteúdo que a gente coloca na clínica não dá muito tempo pra ficar discorrendo sobre questões mais amplas. Então é o técnico, é o palpável então aí eu acho que eles gostam, eu também saio satisfeita, né então é uma coisa que me puxa para o chão (risos...), né não me deixa ficar viajando com eles. Então esse é um momento em que eu estou bem, que eu não estou em conflito nessa parte mais prática. Agora em outros momentos como orientação de trabalhos... quando são contatos mais individuais eu tenho mais facilidade, as minhas ações enquanto docente quando eu trabalho com grupos menores, uma aluna, duas alunas, orientando trabalhos, fazendo uma pesquisa aí vai bem porque é uma interação muito mais próxima agora essa coisa de você dar aula para 70 alunos, com microfone aqui na frente eu acho que complica bastante.

\section{O que você espera agindo desta forma?}

Essa é complicada, hein ? qual é o meu objetivo

maior ... É eu não tenho mais objetivo de transformar ninguém, né nem de formar ninguém porque eu acho que aqui a gente não está conseguindo formar. Eu posso estar informado, isso eu acho que eu faço, eu estou informando e em momentos de contato individual eu acho que eu consigo formar um pouco mais. Mas aqui, no bloco 
teórico, na parte teórica, com aquele monte de conteúdo em pouco tempo para um monte de alunos eu não me sinto, sinceramente, eu me sinto cumprindo uma tarefa. Responder a demanda, eu garanto a presença de todo mundo mas assim o que vai além da informação eu não sei e, ainda uma informação muito limitada. A gente sempre tem muita coisa pra falar, eu acho que a gente tem tão pouca oportunidade de falar sobre essas angústias da profissão, sobre as decepções da profissão, né. É mas eu acho que para essa entrevista é só, talvez num outro momento aí. 


\title{
ENTREVISTA 7 - BURITI
}

\section{Como tem sido suas ações docentes neste curso}

\section{de enfermagem ?}

\begin{abstract}
Eu sempre tenho em
vista estimular o aluno pensando que ele vai poder atuar em 4 áreas e tenho bastante segurança, mesmo não sendo enfermeiro, que ele pode
\end{abstract}

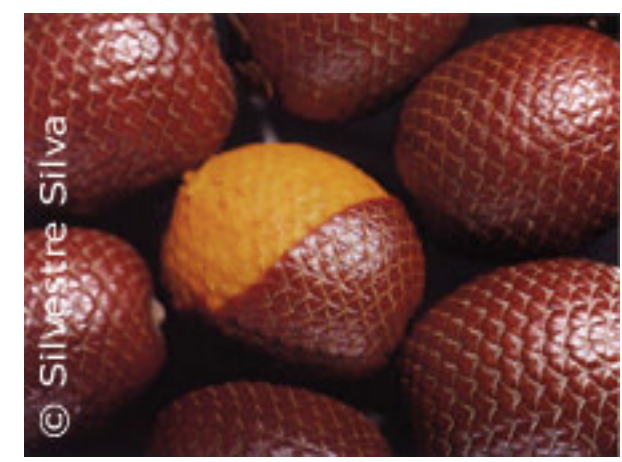
sim conseguir conhecimentos que vão torná-lo um profissional de bom nível. Então eu sempre penso em objetivos da disciplina e busco alcançá-los mesmo não sendo da área. Dou aula em disciplina básica, não é profissionalizante de final de curso, muito específica. São disciplinas mais gerais e eu acredito que muito eu consigo cumprir com essa meta de prepará-los. Então eu preparo as aulas antes, eu tenho um conteúdo para cumprir. Preparo as aulas expositivas, com discussão, procuro pontos polêmicos, estimular raciocínio, informação geral, eu não gosto de nada muito encabrestado. Eu acho que um momento de um aprendizado geral na verdade, é um crescimento muito grande que os alunos apresentam nessa fase, né de vida, de estudo, é um salto muito grande para eles. Quanto mais informação e formação eu puder 
estimular é o que eu faço. Mas sempre procurando os objetivos da aula, os objetivos específicos da aula e até porque não orientá-los em situações pra vida. Então, como se comunicar, como se comportar, como reagir, o que é talvez aí adotado ou percebido como mais normal ou menos normal para um universitário como eles são na época em que eles vivem, no país que eles vivem. Eu acho importante você entender o aluno no universo que ele está, não é? Aqui na universidade eles tem características que são próprias deles e a gente tenta perceber essas características e partindo deste universo estimular para que eles consigam crescer o mais rápido possível na informação e na formação deles como pessoa, no mundo deles e como profissionais. Além das aulas, existe um contato que eu percebo aqui que é fora da aula, que é uma atenção para o aluno, que eles exigem, que eles clamam e que eu atendo na medida do possível sim. Então é uma conversa extra-oficial, de um problema particular, de um problema na família, de um problema que não precisa ser exatamente até de saúde e que as vezes, algumas vezes me sentindo incapaz de resolver, eu sirvo só como ouvinte e as vezes encaminhar para um setor adequado de atendimento. Olha, eu acho que você pode procurar um psicólogo, pode procurar alguém específico para resolver o problema dele. Já aconteceram várias vezes aqui no curso esse tipo de solicitação, para atenção mesmo. Olha, o 
trabalho de pesquisa, o TCC e a IC, que são orientações, eu percebo aqui que eu tenho uma certa dificuldade para fazê-los produzir. Existe uma heterogeneidade muito grande no universo de alunos, então existem grupos que produzem mais do que outros. Mas também é um encontro que nós temos, semanal, onde eu peço algumas tarefas e oriento para que eles busquem a conclusão. Eu tenho um pouco de dificuldade porque são muitas vezes pessoas que nunca fizeram um trabalho desse tipo. Para TCC eles já estão há 4 anos na universidade e eles não tem noções do que é uma introdução de um trabalho, e eles tem orientação que a gente sabe que tem lá em metodologia científica ou o que vocês tem com outro nome na Enfermagem, metodologia da pesquisa científica. Então a gente fica um pouco pasmo de ver que este tipo de coisa muito básica a gente precisa rever muitas vezes e alunos muito cansados. A maioria tem jornada dupla, tripla, estudam, trabalham, trabalham num $2^{\circ}$. emprego, que acho que dificulta um pouco o desempenho. Mas no limite deles produzem, a gente procura estimular o máximo. Então, é variável, não são todos os dias que nós estamos também $100 \%$ favoráveis a orientar mas na medida do possível a gente dá o melhor e exige que eles produzam da melhor forma. Não sei se a resposta vai de encontro a sua pesquisa, senão a gente tem que falar mais alguma coisa. Mas é 
isso, no encontro a gente procura fazê-los produzir um trabalho de pesquisa, seja na IC ou seja no TCC.

\section{O que você espera agindo desta forma?}

Essa pergunta é quase romântica, porque como professor, a gente não é altamente bem pago, não passo necessidades básicas mas a gente não fica rico dano aula e as vezes eu também me pergunto o que que eu quero dando aula, onde eu quero chegar. Mas a resposta vem de forma simples. È uma aptidão que eu acho que eu tenho e facilidade para passar o que eu sei, acho que tenho muito a aprender. Quanto mais eu estudo mais eu acho que eu tenho a aprender e acompanhar as evoluções e tal. Acho que é prazeroso. Então é uma aptidão, eu tenho prazer em dar aula, confesso que estou tentando diminuir um pouquinho a carga porque o excesso de aulas as vezes então torna a gente um pouquinho menos interessante, nas aulas temos que repetir várias vezes, entra naquela repetição e você como professora que é sabe que a gente as vezes repete a mesma aula para turmas diferentes e não me agrada muito isso. Mas no geral, eu faço porque gosto, então não é por dinheiro, não é por poder,é na verdade por uma satisfação, um gosto, uma aptidão. Então eu tenho uma satisfação muito grande quando a gente percebe que uma pessoa partiu de um ponto por si só, não estou dizendo que 
eu sou responsável exclusivo por isso não, mas ela parte de um ponto e com a sua ajuda, com um pouquinho de estímulo, né nesse ensino e aprendizado ela chega a um outro ponto que normalmente é melhor, é além do que ela tinha e esse ganho é muito satisfatório prá mim. A minha intenção é fazer com que ele avance, é o que normalmente acontece, seja mais ou seja menos. Eu acho quase impossível né (risos ...), eu nunca parei para ver isso a fundo, alguém retroceder nesse processo, quase impossível, de repente tem alguém (risos ...) que consegue, né ? É esse o motivo. Quero valorizar o seu trabalho até por ser inédito. Para vocês prestarem atenção nesse direcionamento que é uma tendência hoje de profissionalizar demais a pessoa, eu não estou dizendo que isso aqui aconteça, mas é uma tendência pelo que eu tenho acompanhado, de profissionalizar demais e dar menos importância para o universo que a pessoa vive, para a formação pessoal desse indivíduo que está num contexto e que deve ser considerado, né. Então a gente vê, lógico, algumas iniciativas que vão nesse sentido de você considerar o aluno, a humanização do estudo até a humanização no atendimento em Enfermagem. Eu lembro de ter visto um trabalho até aqui. Mas a tendência é sempre você estreitar, você direcionar para o preparo específico de atuação profissional porque até o mercado prima muito por esse lado. E eu acho que a formação na universidade tem que ser global. Eu 
valorizo mais o indivíduo que cresça não só profissionalmente mas como pessoas também, como indivíduo para ter um desenvolvimento mais pleno, mais completo, mais equilibrado até. Não adianta a gente ter um profissional altamente preparado tecnicamente e intratável como pessoa, e as vezes eu acho, não é obrigatório, mas as vezes eu acho, quanto mais você coloca profissionais para dar aula que são técnicos, tem que tomar cuidado pra eles não valorizarem, só porque eles são técnicos e todo o resto também, eu não sei se ficou claro. Eu não acho que isso vá acontecer obrigatoriamente mas a gente tem que tomar um pouco de cuidado para que isso não aconteça, eu acho, é a minha opinião. 


\section{ENTREVISTA 8 - CASTANHA-DO-BRASIL}

\section{Como tem sido suas ações docentes neste curso}

\section{de enfermagem?}

Tento, né fazer de uma maneira mais próxima do aluno, então as atividades tanto extra classe quanto na classe. Eu acho que a relação docente não só

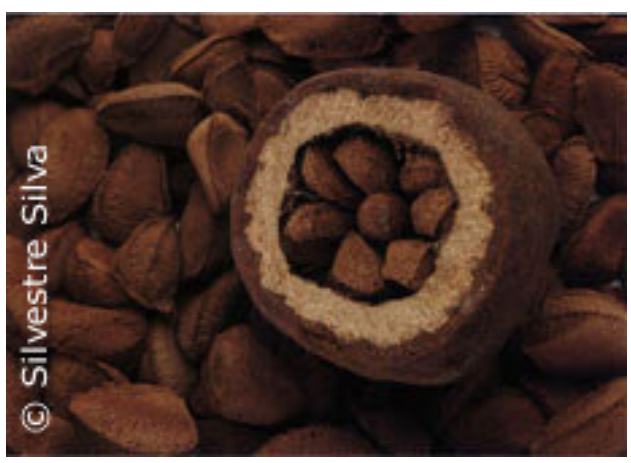
durante a sala de aula, durante a aula com atividades formais como em corredores, em conversa com os alunos de uma maneira sempre muito próxima deles. De uma maneira sempre a mostrar a minha vivência profissional como um exemplo pra eles. Então durante as aulas eu tento sempre trazer a minha vivência profissional daquele assunto como um exemplo pra ele, não digo como um espelho, mas assim pra ele ter noção do como é ser enfermeiro. Então o tempo todo eu mostro pra eles o que eu fui, ou o que eu sou, se é que eu ainda sou, como enfermeira para que eles até tenham um parâmetro de bom profissional ou ruim profissional de acordo com os critérios do que eles estão vivenciando, que alguns são da área de saúde, outros não mas sempre pensando assim, de ser um exemplo de pessoa, de 
professor, de me desculpar em cima de erros, mas sempre tentando ser um exemplo, acho de profissional. Eu dou várias disciplinas no curso então eu dou disciplinas técnicas específicas de Enfermagem tipo Saúde do Adulto, Saúde do Idoso, UTI e OS e dou agora esse ano disciplinas mais básicas que é a História da Enfermagem, para $\circ 1^{\circ}$. semestre e Didática para $\circ 3^{\circ}$. semestre. Nas aulas dessas matérias básicas que a gente sabe até que não são matérias que eles gostam, porque eles acham que ser enfermeiro não precisa ver outra coisa a não ser doença, eu tento sempre trazer exemplos da Enfermagem, mesmo na História da Enfermagem eu tento puxar pra nossa vivência atual, do que ... que fatos históricos tem hoje na Enfermagem, tento sempre mostrar a influência que isso teve sempre mostrando os hospitais que eu trabalhei, os hospitais que eu acompanhei estágio. Nas disciplinas técnicas Adulto, Idoso, UTI e OS é ... dou aula de uma maneira um pouco mais lúdica, eu sou muito brincalhona, né, brinco muito com as situações mas sempre tentando trazer a vivência hospitalar que eu tive, que é a maior experiência que eu tive. Nas atividades extra classe tipo IC, orientação de TCC, eu tento ser muito amiga deles, muito parceira, ouvindo muito o que eles falam, tentando mostrar pra eles que o fato se se tornar enfermeiro, que isso faz parte da formação de enfermeiro. Então fazer um TCC mesmo que não seja da vontade deles ser um 
pesquisador, que como é exigência do currículo, que mesmo não sendo exclusivamente pesquisador, como enfermeiro ele vai ter que ter essa curiosidade investigativa, uma coisa de participação da formação deles mesmo que eles não vejam importância como pesquisador, mas sempre muito como parceira, como amiga deles tentando sempre mostrar que ... muitos como são profissionais de Enfermagem já, eles tem a visão do enfermeiro aquele ser mandão, aquele ser autoritário, eu tento tirar um pouco isso deles. Que dá pra você ser amigo, ser chefe e ser amigo ao mesmo tempo, que você precisa ter muito conhecimento pra você poder mandar, mas o mandar não significa impor a sua vontade com o seu funcionário mas dividir com ele, negociar com ele, participar, né, mostrar a minha vivência como supervisora, que eu nunca fui uma pessoa muito rude, que lês tem essa vivência que eles trazem né de enfermeiro, como aquele que manda, aquele que briga. Eu tento mostrar pra eles que não é assim mas mostrando sempre a importância que você só vai ser um bom profissional se você tiver conhecimento, se você for humano, sempre mostrando o que eu sou como profissional, pelo menos o que eu imagino ser como profissional. 


\section{O que você espera agindo desta forma?}

Então quando eu comecei dar aula não nessa escola mas numa outra escola, eu tinha na minha cabeça assim que eu não queria ver os profissionais que eu participava ou participo da formação com nível de formação dos enfermeiros que eu via no hospital onde eu trabalhava. Então meu objetivo é fazer deles enfermeiros com eu imagino que deve ser a formação de um bom profissional. Com isso eu já, falei assim, aliar conhecimento com a parte humana, com a parte de sensibilidade, de não ser pessoas ... ainda mais os que já são profissionais de nível médio, que eles acham que tem que ser enfermeiro só porque vão mandar. Eu falo que isso não é importante. Formar um enfermeiro que como eu gostaria de ter trabalhando comigo. Assim, bons profissionais, profissionais tecnicamente bons mas sempre tendo esse outro lado, o lado humano, o lado de cooperação, o lado de saber trabalhar em equipe mas especialmente de serem bons tecnicamente. Eu acho que o que eu senti mais como gerente, né, no cargo de gerência no hospital era a falta de conhecimento técnico. Então eu exijo muito deles nesse sentido, que tem que ser bom tecnicamente e pra isso precisa estudar. Eu mostro isso pra eles o tempo todo e tento mostrar assim, de uma maneira até respondendo perguntas de outras disciplina, mostrando pra eles que o conhecimento da gente 
é um conhecimento inteiro, não é só de uma determinada especialidade „, que o profissional tem que ter uma outra vivência. O fato de eu estar dando Didática esse ano tá fazendo eu mudar ainda mais esse lado de mostrar mesmo pra eles que o profissional bom é aquele profissional inteiro. Mesmo que ele seja um especialista mas que ele seja inteiro, assim bem formado, que fale bem, que saiba ler, que tenha postura, que eu brinco com eles com os "pobrema" eu to fora, né eu quero pessoas que falem bem, que saibam se portar, que eu sempre falo pra eles uma frase que eu dizia no hospital: quando fala o fulano de tal fez alguma coisa errada está se referindo àquela pessoa mas quando fala o enfermeiro fez aquela coisa errada está se referindo a mim também porque eu também sou enfermeira. Então nesse sentido eu faço deles, tento né fazer, pretensão a minha querer fazer, mostrar pra eles a importância de ser um profissional que seja inteiro, assim uma pessoa culta, uma pessoa que leia, uma pessoa que fale bem, que se porte bem, que tenha postura, que saiba chefiar sem ser rude, que saiba liderar um grupo sem ser mandão, sem ser autoritário. Acho que é isso. Acho que assim, uma coisa que eu tenho repensado ultimamente é assim, se eu sou enfermeira ou se eu sou professora. Acho que eu estou numa crise nesse momento de querer ser boa professora mas ainda achar que sou enfermeira. Então acho que essa coisa de formação docente é 
uma coisa que agora está pegando. Sempre que falo que agora eu sou só professora, que é o que eu falo, as pessoas falam: agora você não, trabalha, você só dá aula! como se fosse fácil, né ? Eu tenho que me preocupar um pouquinho com essa formação docente. Então eu tenho lido algumas coisas, tenho procurado algumas coisas pra tentar ver se eu sou mesmo professora ou se eu sou uma enfermeira brincando de professora porque eu estou num momento de reflexão nesse sentido. 


\section{ANEXO 5}

\section{CONSTRUINDO AS CATEGORIAS DO VIVIDO}

\begin{tabular}{|c|c|c|c|c|c|c|c|c|c|}
\hline CATEGORIAS $\quad$ ENTREVISTAS $\Rightarrow$ & 1 & 2 & 3 & 4 & 5 & 6 & 7 & 8 & Total \\
\hline O aluno como futuro profissional & $\mathrm{X}$ & $\mathrm{X}$ & & $x$ & $x$ & $\mathrm{X}$ & $\mathrm{x}$ & $\mathrm{x}$ & 7 \\
\hline As estratégias de ensino & $x$ & & $\mathrm{X}$ & & $x$ & & $\mathrm{X}$ & $\mathrm{X}$ & 5 \\
\hline Os conteúdos & $\mathrm{x}$ & & $x$ & $x$ & $x$ & $x$ & $x$ & $\mathrm{x}$ & 7 \\
\hline O trabalho em equipe & $x$ & & & & & & & & 1 \\
\hline O docente como pesquisador & $x$ & $\mathrm{x}$ & $\mathrm{X}$ & & $x$ & & & $\mathrm{X}$ & 5 \\
\hline O crescimento pessoal do aluno & $\mathrm{X}$ & $\mathrm{X}$ & & $\mathrm{X}$ & & & $\mathrm{X}$ & $x$ & 5 \\
\hline $\begin{array}{l}\text { A estrutura universitária dificultando a } \\
\text { ação docente }\end{array}$ & & $x$ & & & $x$ & $\mathrm{x}$ & & & 3 \\
\hline Sentimentos distintos & & $\mathrm{x}$ & $\mathrm{x}$ & $x$ & $x$ & $x$ & $\mathrm{x}$ & & 6 \\
\hline Visão do que é ser docente & & $\mathrm{X}$ & & $\mathrm{x}$ & $\mathrm{x}$ & $x$ & $x$ & $x$ & 6 \\
\hline O perfil do aluno & & $x$ & & $x$ & $x$ & $x$ & $x$ & & 5 \\
\hline Relação professor aluno & & & $x$ & & $\mathrm{x}$ & & $\mathrm{x}$ & $x$ & 4 \\
\hline Pensando na própria formação & & & & & $x$ & & & $x$ & 2 \\
\hline Avaliação & & & & & $\mathrm{x}$ & & & & 1 \\
\hline O trabalho multidisciplinar & $\mathrm{x}$ & & & & $x$ & & & $\mathrm{X}$ & 3 \\
\hline
\end{tabular}

Números ímpares = docentes de outras áreas da saúde

Números pares $=$ docentes enfermeiros 
1 CONTANDO MEU CAMINHO PROFISSIONAL 


\section{A PRÁtICA DOCENTE NO ENSINO DE}

ENFERMAGEM 
4 APRESENTANDO O REFERENCIAL METODOLÓGICO 
6 CONSTRUINDO AS CATEGORIAS CONCRETAS DO VIVIDO 


\section{CONSTRUÇÃO DO TIPO VIVIDO}


